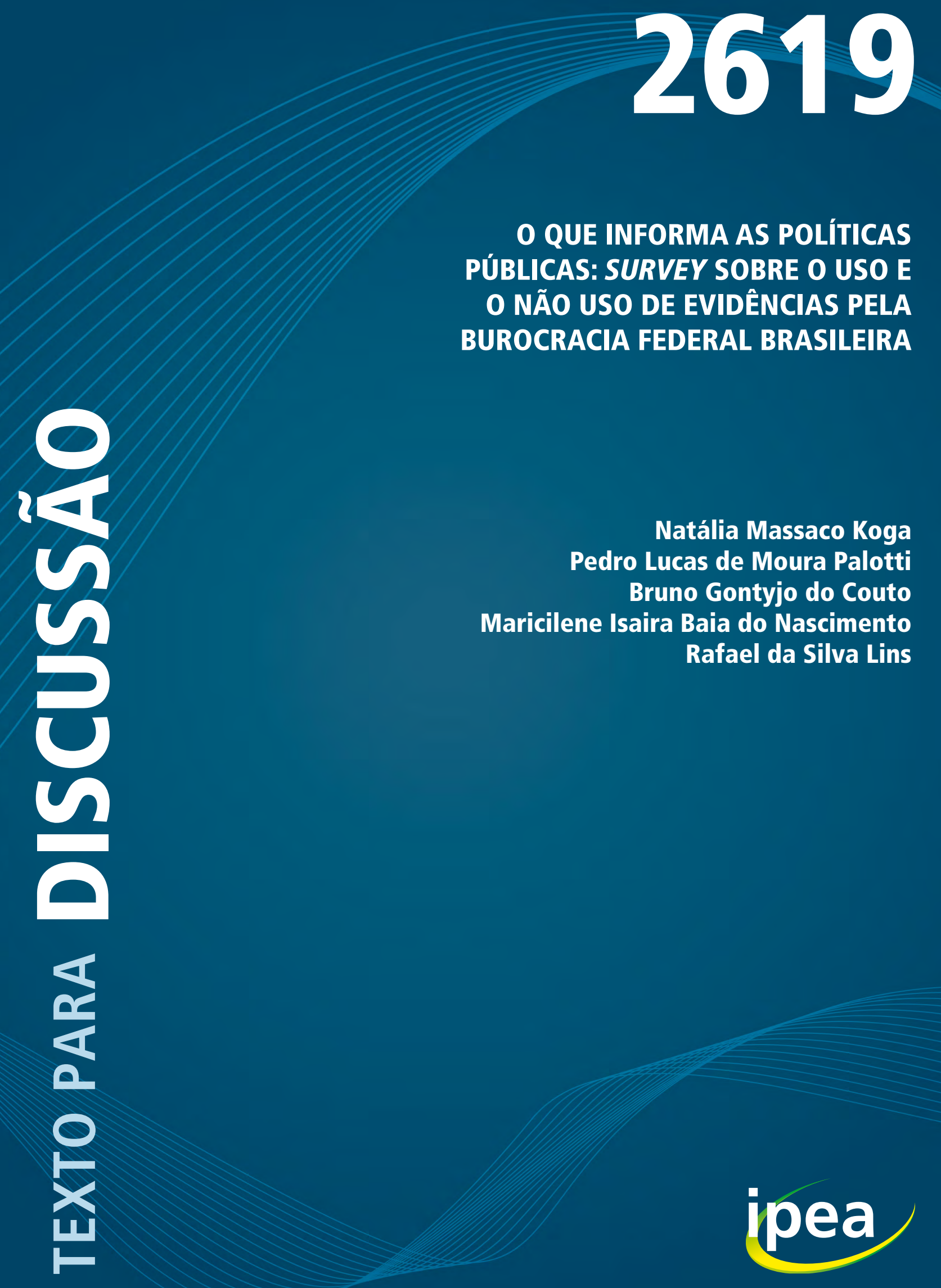





\title{
O QUE INFORIMA AS POLÍTICAS PÚBLICAS: SURVEY SOBRE O USO E O NÃO USO DE EVIDÊNCIAS PELA BUROCRACIA FEDERAL BRASILEIRA ${ }^{1,2}$
}

\author{
Natália Massaco Koga ${ }^{3}$ \\ Pedro Lucas de Moura Palotti ${ }^{4}$ \\ Bruno Gontyjo do Couto ${ }^{5}$ \\ Maricilene Isaira Baia do Nascimento ${ }^{6}$ \\ Rafael da Silva Lins ${ }^{7}$
}

1. 0 survey apresentado neste Texto de Discussão (TD) faz parte do projeto de pesquisa 0 que informa as políticas públicas federais: o uso e o não uso de evidências pela burocracia federal produtora de políticas públicas e pela burocracia do controle, coordenado pela Diretoria de Estudos e Políticas do Estado, das Instituições e da Democracia (Diest) do Ipea, em parceria com pesquisadores da Escola Nacional de Administração Pública (Enap), da Companhia de Planejamento do Distrito Federal (Codeplan-DF), do cluster de governança do Institute of Development Studies (IDS) do Reino Unido (IDS) e da Lee Kuan Yew School of Public Policy da National University of Singapore (LKY/NUS).

2. Os autores agradecem os ótimos pareceres e comentários de Roberto Pires e Janine Mello a uma versão anterior deste TD. Erros e omissões são de responsabilidade exclusiva dos autores.

3. Especialista em políticas públicas e gestão governamental (EPPGG) em exercício no Ipea. E-mail: <natalia.koga@ipea.gov.br>.

4. EPPGG em exercício no Ipea. E-mail: <pedro.palotti@ipea.gov.br>.

5. Pesquisador do Subprograma de Pesquisa para o Desenvolvimento Nacional (PNPD) na Diest/lpea. E-mail: $<$ bruno.gontyjo@ipea.gov.br>.

6. Pesquisadora do PNPD na Diest//pea. E-mail: <maricilene.nascimento@ipea.gov.br>.

7. Pesquisador do PNPD na Diest//pea. E-mail:<rafael.lins@ipea.gov.br>. 


\section{Governo Federal \\ Ministério da Economia \\ Ministro Paulo Guedes}

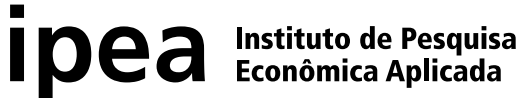

Fundação pública vinculada ao Ministério da Economia, o Ipea fornece suporte técnico e institucional às ações governamentais - possibilitando a formulação de inúmeras políticas públicas e programas de desenvolvimento brasileiros - e disponibiliza, para a sociedade, pesquisas e estudos realizados por seus técnicos.

\section{Presidente}

Carlos von Doellinger

Diretor de Desenvolvimento Institucional Manoel Rodrigues Junior

Diretora de Estudos e Políticas do Estado, das Instituições e da Democracia

Flávia de Holanda Schmidt

\section{Diretor de Estudos e Políticas \\ Macroeconômicas \\ José Ronaldo de Castro Souza Júnior}

Diretor de Estudos e Políticas Regionais, Urbanas e Ambientais

Nilo Luiz Saccaro Júnior

Diretor de Estudos e Políticas Setoriais de Inovação e Infraestrutura

André Tortato Rauen

\section{Diretora de Estudos e Políticas Sociais}

Lenita Maria Turchi

Diretor de Estudos e Relações Econômicas

e Políticas Internacionais

Ivan Tiago Machado Oliveira

\footnotetext{
Assessor-chefe de Imprensa

e Comunicação (substituto)

João Cláudio Garcia Rodrigues Lima

Ouvidoria: http://www.ipea.gov.br/ouvidoria

URL: http://www.ipea.gov.br
}

\section{Texto para Discussão}

Publicação seriada que divulga resultados de estudos e pesquisas em desenvolvimento pelo Ipea com o objetivo de fomentar o debate e oferecer subsídios à formulação e avaliação de políticas públicas.

(C) Instituto de Pesquisa Econômica Aplicada - ipea 2020

Texto para discussão / Instituto de Pesquisa Econômica Aplicada.- Brasília : Rio de Janeiro : Ipea, 1990-

ISSN 1415-4765

1.Brasil. 2.Aspectos Econômicos. 3.Aspectos Sociais. I. Instituto de Pesquisa Econômica Aplicada.

CDD 330.908

As publicações do Ipea estão disponíveis para download gratuito nos formatos PDF (todas) e EPUB (livros e periódicos).

Acesse: http://www.ipea.gov.br/portal/publicacoes

As opiniões emitidas nesta publicação são de exclusiva e inteira responsabilidade dos autores, não exprimindo, necessariamente, o ponto de vista do Instituto de Pesquisa Econômica Aplicada ou do Ministério da Economia.

É permitida a reprodução deste texto e dos dados nele contidos, desde que citada a fonte. Reproduções para fins comerciais são proibidas. 


\section{SUMÁRIO}

SINOPSE

ABSTRACT

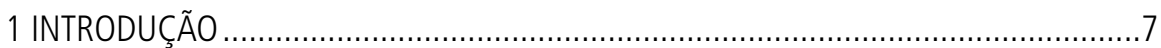

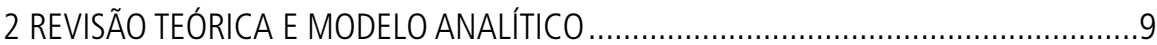

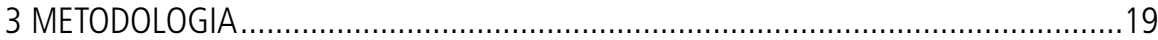

4 RESULTADOS

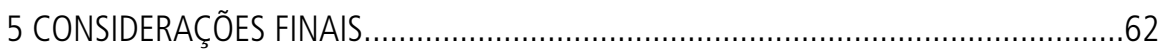

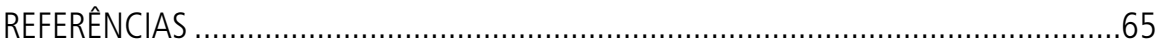

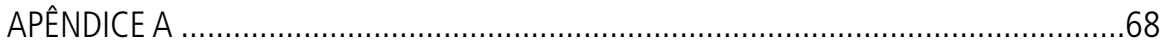

ANEXO A 



\section{SINOPSE}

Este texto para discussão (TD) visa apresentar os principais resultados de um survey aplicado com a burocracia pública da administração direta em âmbito federal, com o objetivo de compreender os usos de diferentes fontes de evidências para produção de políticas públicas. Ao todo, foram respondidos 2.180 questionários no período de outubro a dezembro de 2019. Os resultados apontam para a existência de diferentes perfis de funçóes desempenhadas, com destaque para um perfil dedicado à produção de análises e assessoramento governamental. Quanto à mobilização de fontes de informação, os dados indicaram quatro perfis de burocratas: os que se baseiam em informaçóes produzidas pela própria administração pública; outros que se apoiam em diversos tipos de informações externas; um terceiro grupo que utiliza informaçóes de fontes acadêmicas; e, por último, um perfil que confia em informaçôes de cunho mais pessoal. Especificamente quanto às evidências científicas, a credibilidade e o prestígio da fonte, além da aplicabilidade dos estudos produzidos, são fatores que ampliariam sua utilização em âmbito federal. Não se observaram, do ponto de vista organizacional, muitas estratégias para incorporaçáo e disseminação de um enfoque de políticas públicas baseadas em evidências (PPBEs), havendo principalmente esforços individuais para utilizar evidências científicas no processo decisório.

Palavras-chave: produção de políticas públicas; tomada de decisão em políticas públicas; políticas públicas baseadas em evidências; burocracia governamental; administração pública federal; Brasil.

\section{ABSTRACT}

The present Text for Discussion aims to present the main results of applied research with the federal bureaucracy in direct administration to understand the uses of different sources of information in policy making. At all, 2,180 questionnaires were answered in the period from October to December 2019. The results point out different profiles of functions performed by bureaucrats, with emphasis on a profile dedicated to the production of government analysis and advisory. As for the mobilization of informational sources, there are four types: those that rely on information produced by Public Administration, others that are based on different forms of external information, a third type that uses information from academic sources and, finally, a profile that have more confidence in personal sources. In relation more specifically to scientific evidence, the credibility and prestige of the source and the applicability of the studies are factors that increase its use 
at the federal bureaucracy. From an organizational point of view, there are few strategies for the incorporation and dissemination of an evidence-based public policies approach. Efforts to use scientific evidence were found mainly in the individual level.

Keywords: policy making; decision making in public policies; evidence based public policy; bureaucracy; federal public administration; Brazil. 


\section{INTRODUÇÃO}

A produção de políticas públicas é um processo complexo que envolve um conjunto de estímulos e condicionantes. Compreender o que informa os burocratas e as organizaçôes públicas nesse processo é um tópico relevante e de crescente interesse nos estudos de políticas públicas, especialmente no debate sobre os benefícios e os limites da abordagem das políticas públicas baseadas em evidências (PPBEs). Diferentes fatores que condicionam as funçôes de políticas do Estado podem ser explorados, tais como: capacidades individuais e organizacionais de apreensão e processamento de informaçóes; constrangimentos sociais, econômicos e político-institucionais; mudanças tecnológicas; crises de toda natureza; diferenças em custos e benefícios e na sua percepção pelos agentes; inércia organizacional; entre outros. Nesse contexto, a disponibilidade e a utilização de evidências são um desses fatores intervenientes do processo decisório e de produção das políticas públicas.

Em primeiro lugar, cabe destacar que o sentido de evidências é abrangente. Há estritamente a evidência científica, em voga nas discussóes sobre PPBEs, entendida por seus defensores como "resultados de pesquisas sistemáticas voltadas ao acúmulo crescente de conhecimento" (Davies, Nutley e Smith, 2000, p. 3, tradução nossa). ${ }^{1}$ Ocorre, no entanto, que em muitas ocasiōes o acesso e a utilização de evidências científicas são limitados. Ademais, estudos e avaliaçóes demandam um esforço analítico conjunto de diferentes atores - em particular de pesquisadores e gestores - para produção de conhecimento aplicado e sistematizado, com o objetivo de subsidiar o processo decisório. Nesse sentido, a literatura já observava, nos processos reais de produção de políticas públicas, a racionalidade limitada dos atores e o uso de atalhos cognitivos que se distanciam do uso instrumental de evidências científicas apregoado pela PPBE (Lindblom, 1959). Com isso, muitas vezes, a depender do contexto decisório, outros tipos de evidências são mobilizados: experiências pessoais ou organizacionais anteriores; opinióes dos beneficiários das políticas públicas e interessados nestas; divulgaçôes produzidas pela mídia ou por redes sociais; impressóes recolhidas de colaboradores internos e externos; etc.

1. Seguindo a proposta de Pinheiro (no prelo), exemplos não exaustivos do entendimento de evidências científicas neste estudo seriam: "os conhecimentos produzidos a partir de métodos que abranjam pelo menos um dos seguintes itens: i) identificação precisa de um problema de pesquisa, com variáveis dependente e independentes bem delimitadas; ii) revisão da literatura acadêmica sobre o assunto; iii) coleta sistemática de dados e informações; iv) tratamento dos dados e informações com métodos quantitativos ou qualitativos rigorosos; v) discussão detalhada dos resultados; vi) publicação dos resultados em periódicos científicos; vii) publicação em periódicos de universidades ou institutos de pesquisa". 
Além da proveniência ou natureza das evidências, cabe destacar seus diferentes possíveis usos. O mais comum e debatido é o uso para subsidiar o processo decisório. Sua utilização por esse aspecto assume caráter instrumental e é muito ressaltada na literatura que defende a abordagem da PPBE. Há uma segunda possibilidade, que é sua utilização para compreender ou esclarecer conceitos. Em muitos casos, esse sentido estará presente quando se tratar de revelar aspectos relacionados a determinado problema de política pública. A inserção de problemas públicos na agenda governamental em muitos casos demandará a mobilização de evidências. Por fim, há a utilização de evidências de modo pontual, com o objetivo de justificar decisóes já tomadas. É praticamente o inverso de sua utilização instrumental. Evidências são utilizadas estritamente para conferir maior legitimidade a decisóes prévias (Weiss, 1979; Amara, Ouimet e Landry, 2004).

Especificamente no âmbito das organizaçóes públicas, além dos fatores organizacionais comumente presentes em organizaçóes privadas, pode-se destacar a presença da dimensão política como elemento central para conformação do processo decisório. Seja pela interação permanente com os agentes políticos, seja pela interlocução com cidadãos quando são implementados serviços públicos, a dimensão política assume uma faceta permanente para a produção de políticas públicas. Ignorar esse aspecto torna os modelos decisórios pouco eficazes para entender a realidade da atuação governamental. Esse é um elemento central para compreensão do que informa as políticas públicas, tornando mais realista a apreensão do processo decisório no âmbito das organizaçôes públicas.

Esta pesquisa foi realizada a partir da elaboração de um instrumento de survey organizado com base em pesquisas anteriores conduzidas com servidores públicos em outros países (Ouimet et al., 2009; Cherney et al., 2015; Veselý, Ochrana e Nekola, 2018) e dos resultados de pesquisa obtidos com um survey produzido para a mesma populaçáo de servidores federais (Enap, 2018). ${ }^{2}$ Foram respondidos 2.180 questionários válidos, a partir de uma amostra para a administraçáo pública direta. $\mathrm{O}$ objetivo da pesquisa foi compreender as diferentes evidências utilizadas pela burocracia federal. Partindo-se das premissas de outros estudos internacionais, foi dado maior enfoque aos determinantes da utilização das evidências científicas. Contudo, foram levantados dados que permitem análises futuras acerca da influência de outras fontes de evidência.

2. A pesquisa anterior buscou mapear funções e capacidades de produção de políticas públicas entre a burocracia federal. Na pesquisa atual, o foco está na chamada capacidade analítica, como discutido na seção de discussão da literatura. 
Este TD, além desta introdução, está dividido em mais quatro seçôes. A seguir, na seção 2, será realizada uma revisão teórica, com o intuito de destacar os principais marcos analíticos e o modelo teórico adotado para o projeto de pesquisa $O$ que informa as políticas públicas federais: o uso e o não uso de evidências pela burocracia federal produtora de politicas públicas e pela burocracia do controle, que abarca este estudo e outras etapas que ainda serão implementadas. Na seção 3, serão detalhados os métodos empregados; em particular, a elaboração do questionário de pesquisa, a amostragem realizada e os instrumentos de coleta e análise dos dados. $\mathrm{Na}$ seção 4, são apresentados os principais resultados. Nas considerações finais, há implicações práticas dos resultados obtidos, bem como os delineamentos para uma agenda futura de pesquisa.

\section{REVISÃO TEÓRICA E MODELO ANALÍTICO}

Esta seção se dedica a trazer alguns marcos importantes do desenvolvimento do campo de análise de políticas públicas nos contextos internacional e brasileiro para o estudo do objeto desta pesquisa. Esse resgate se fez relevante por três principais motivos. O primeiro destes porque permitiu verificar que muito das raízes e das críticas ao movimento de $\mathrm{PPBEs}^{3}$ náo é novo e merece ser articulado com o que já foi debatido a respeito na trajetória de constituição desse campo de estudo. O segundo motivo seria por ter proporcionado maior compreensão das diferenças da conformação dos estudos de políticas públicas no Brasil e dos países em que a PPBE emerge. Por fim, o terceiro motivo trata de justificar a opçáo desta pesquisa por buscar conhecer náo apenas o uso pelos burocratas de evidências científicas, mas também de diversos recursos e instrumentos informacionais. Esse argumento se sustenta a partir trabalhos produzidos por essa literatura, que demonstra como outros tipos de evidência são constantemente utilizados por diversos atores e em diversos momentos na produção de políticas públicas.

Partindo-se, assim, de uma visão não restritiva do que seriam evidências e da literatura levantada, foi proposto um modelo teórico-analítico para o projeto de pesquisa que tem este estudo empírico como sua primeira fase.

3. Para debate mais aprofundado sobre a origem e a expansão do movimento da PPBE, ver o TD no 2.554 do Ipea, produzido por Maurício Mota Saboya Pinheiro, intitulado Políticas Públicas Baseadas em Evidências (PPBEs): delimitando o problema conceitual (Pinheiro, 2020). De forma simplificada, para este estudo, entendemos a PPBE como um movimento que defende uma abordagem mais racional, rigorosa e sistemática na produção de evidências - portanto, científicas - a embasarem a tomada de decisão nas políticas públicas. Em que pese a existência de divergências quanto a intensidade de rigor e diversidade de técnicas no movimento, podemos afirmar que a PPBE traz em sua raiz uma visão otimista e prescritiva quanto à capacidade da racionalidade ser aplicada para gerar melhores resultados nas políticas públicas. 


\subsection{As tradições teóricas da literatura de análise de políticas públicas e o movimento da PPBE}

O campo de análise de políticas públicas foi originalmente proposto, no contexto anglo-saxão, como uma ciência voltada ao aprimoramento do uso da racionalidade no fluxo decisório das políticas públicas (Lasswell, 1951). Buscando subsídios de outros campos do conhecimento para as questóes substantivas específicas das distintas áreas de políticas públicas e gerando conhecimento sobre o próprio processo de execução e produção das políticas (Lasswell, 1970), o campo avançou no sentido de ampliar seu foco para além da tomada de decisóes.

Trabalhos empíricos passam a demonstrar que os resultados de políticas públicas não apenas decorriam das melhores escolhas na formulação, mas também que elementos e dinâmicas do processo de implementação mereceriam ser examinados (Pressman e Wildavsky, 1973). A concepção da política pública como um ciclo linear e cumulativo de etapas, assim como a dicotomia entre a técnica e a política são crescentemente questionados (Simon, 1956; Lindblom, 1959; Lindblom e Cohen, 1979).

Ao longo das décadas, essa literatura se expande tanto em relação a áreas temáticas, como a abordagens analíticas que passam a questionar o paradigma da racionalidade instrumental, a qual embasou o início da construção do campo. Ainda nos anos 1950, autores como Herbert Simon e Charles Lindblom confrontam tais fundamentos calcados na ideia da perfeita separação entre o técnico e o político e na viabilidade da racionalidade objetiva, plena e isenta de interferências subjetivas.

Simon (1956), em sua crítica aos pressupostos da escolha racional, sustenta que, no momento decisório, os indivíduos conseguem explorar apenas um número limitado de alternativas. Isso não significa que não haja racionalidade nesse processo, mas que essa racionalidade é subjetiva - isto é, condicionada à interpretaçáo do decisor de que aquela é a melhor decisão entre as alternativas reconhecidas naquele momento. Seria o satisficing solution, uma combinação entre satisfação e suficiência para a necessidade em questão. Com base nas elaboraçóes de Simon (1956), Lindblom (1959) identifica distintas estratégias cognitivas utilizadas pelos indivíduos; entre estas, o incrementalismo, processo sucessivo de tentativa e erro utilizado para redução das alternativas, que acaba por favorecer soluçôes conhecidas. Reconhecido e sustentado por observaçôes empíricas, o incrementalismo revelaria que as soluções não advêm dos fins, mas de um método que busca favorecer pequenas mudanças em detrimento de grandes transformaçôes. 
O reconhecimento de que o campo das políticas públicas é orientado por valores e que a oposição ou separação entre conhecimento técnico e política são irreais vem ganhando força nas últimas décadas, a partir de trabalhos embasados em abordagens pós-positivistas e pós-estruturalistas (Fischer e Gottweis, 2012; Lejano, 2006; Spink, 2019). A concepção da política pública como construçáo argumentativa e discursiva, trazida por autores como Frank Fischer, é uma das principais alternativas analíticas em desenvolvimento no campo da análise de políticas públicas contemporâneo. O movimento da "virada argumentativa" fundamenta-se no "reconhecimento de que a linguagem não apenas reflete o que concebemos como realidade, mas também constitui, molda e, por vezes, até mesmo determina o que entendemos por realidade" (Fischer e Gottweis, 2012, p. 8, tradução nossa). A realidade, portanto, não é algo a ser descoberto externamente, mas é algo a ser percebido como produto da prática discursiva. $\mathrm{O}$ argumento passa, assim, a ser tratado como unidade de análise (op. cit.). Compreendendo que toda ação humana é intermediada e imersa em um rico contexto simbólico social e cultural e entendendo a política pública (prática discursiva) como uma ação humana, ideias e valores passam a ser considerados e observados na análise das políticas públicas por essa abordagem.

Além da abordagem argumentativa, outras correntes surgem ao longo das décadas, incorporando outros elementos na análise de políticas públicas, tais como o papel das instituiçôes, das redes de atores, da participação dos cidadáos, de ideias, valores, crenças, entre outros, na produção das políticas públicas (DeLeon, 2008; Farah, 2018).

No Brasil, no entanto, o processo de formação de um campo de análise de políticas públicas não ocorre de forma sistematizada, rumo à institucionalização de uma disciplina com formação acadêmica própria. Entretanto, como apontam Vaitsman et al. (2013), isso náo significou que a atividade de análise de políticas públicas não tenha sido realizada no país. Entre 1930 e 1980, a análise de políticas públicas não se distinguia da atuação de burocratas de alto escalão envolvidos em comissóes e instituiçôes voltadas à elaboração de propostas para a implementação do projeto nacional-desenvolvimentista. Com a Constituição Federal de 1988 (CF/1988), o processo de produção de políticas torna-se menos centralizado, abrindo espaços para deliberação e dinâmicas decisórias mais horizontais e de origem bottom-up. Instâncias participativas e de deliberação são criadas, e outros atores, para além das fronteiras das organizaçôes estatais, passam a produzir e demandar a produçáo de conhecimento e subsídios acerca das políticas públicas (op. cit.).

Meio século após as primeiras formulaçóes sobre o campo de análise de políticas pública, o movimento da política pública baseada em evidência traz como seu argumento central a defesa do uso de evidências - entendidas como "resultados de pesquisas 
sistemáticas voltadas ao acúmulo crescente de conhecimento" (Davies, Nutley e Smith, 2000, p. 3) - para fins de melhoria das políticas públicas. Diante da complexificação dos problemas públicos, acompanhada da crescente multiplicidade de recursos informacionais disponíveis para capturar e lidar com estes, a PPBE ganhou força nas últimas duas décadas entre acadêmicos, policy makers e practitioners, ao sustentar a lógica de racionalização e eficácia da produção das políticas públicas calcada em evidências "cientificamente comprovadas" (op. cit.).

Embora o movimento da PPBE reconheça a não linearidade do processo de produção do conhecimento científico e a prática na política pública, estudos recentes retomam críticas da literatura de políticas públicas quanto à exacerbação da capacidade de influência da técnica ignorando o poder da política e a relevância de aspectos como valores, princípios e julgamentos no processo decisório das políticas públicas (Cairney, 2019; Parkhurst, 2017). Questiona-se, nesse sentido, a viabilidade da PPBE em contextos de ausência ou pouca disponibilidade de evidências e os limites da racionalidade objetiva dos atores que podem gerar vieses de seleção e interpretação de evidências; questionam-se também os próprios instrumentos analíticos em dar explicaçôes em contextos de alta complexidade (Cairney, 2019; Parkhurst, 2017).

Importante abordagem que faz frente aos argumentos do movimento da PPBE trata dos diferentes tipos de uso das evidências científicas. Amara, Ouimet e Landry (2004) apontam três grandes tipos de uso de pesquisas científicas, partindo dos respectivos modelos de tomada de decisão desenvolvidos nos estudos de políticas públicas. O problem-solving model, baseado na ideia do processo racional, sequencial e linear, em que há relação direta entre evidências e decisóes, assumiria um uso instrumental das pesquisas. O segundo, o modelo do garbage-can, o qual entende o processo decisório como frequentemente anárquico e imprevisível se comparado ao modelo racional (Cohen, March e Olsen, 1972), teria um uso difuso e indireto das pesquisas, de forma mais conceitual que instrumental (Cohen e Lindblom, 1979; Weiss, 1979; Weiss e Bucuvalas, 1980). Por fim, o terceiro modelo seria o que se pode designar como modelo político de tomada de decisão - isto é, o que considera o conflito e a barganha como partes integrantes do processo decisório. No caso desse modelo, as pesquisas são escolhidas para apoiar decisóes já tomadas e utilizadas como political ammunition (Weiss, 1979).

Como argumenta Weiss (1979), ao reconhecer os diferentes tipos de uso, é possível abandonar uma posição prescritiva em relação à produção científica e compreender que distintos usos coexistem e que estes são condicionados ao contexto da tomada de decisão. 
Nesse mesmo sentido, Pinheiro (2020) atenta para o fato de que a própria definição de evidências no campo das políticas públicas é disputável. Em um extremo, calcada no paradigma racionalista, encontra-se a ideia da evidência como resultado da produção científica rigorosa e sistemática, reveladora da "verdade". Mas ao longo desse espectro, outros fatores oriundos das formulaçôes dos paradigmas construtivistas ${ }^{4}$ já mencionados passam a ser reconhecidos como relevantes para a tomada de decisão e produçáo de políticas públicas, tais como a contingência histórica própria dos fenômenos sociais, os interesses, os valores e as motivaçóes dos atores, bem como a reflexividade interativa entre atores e entre atores e objetos.

\subsection{A função analítica na produção das políticas públicas}

Um desdobramento da literatura contemporânea sobre políticas públicas que apresenta interface com o debate da PPBE trata da multiplicidade de funçôes que vêm sendo desempenhadas pelo Estado e por atores externos na produção da política pública no contexto atual de complexificação dos problemas públicos. Assim, por exemplo, além da função política de tomada de decisão e da função administrativa de operacionalizar o aparato estatal, ganha relevância a função analítica de produção e mobilização de conhecimento, como algumas das principais funções que demandam capacidades (policy capacity) e compóem o trabalho na política pública (policy work) (Ramesh et al., 2016).

Da perspectiva do Estado, diversas formulações foram construídas para o conceito de policy capacity. No entanto, seja entendendo-a como habilidade do governo para realizar escolhas inteligentes (Painter e Pierre, 2005), para mapear o ambiente e definir direçóes estratégicas (Howllet e Lindquist, 2004), ou, ainda, de forma mais ampliada, como conjunto de habilidades e recursos necessários para o desempenho das funçôes de políticas públicas (Wu, Ramesh e Howlett, 2015), todas essas concepçôes dão grande ênfase à dimensão analítica entre os recursos estatais necessários para viabilizar a melhor condução das políticas públicas. Nesse sentido, toma-se a capacidade analítica tanto dos burocratas como das organizaçôes públicas como condicionante fundamental para viabilizar o fluxo da inteligência sobre e para as políticas públicas, no tocante às instâncias decisórias dessas políticas (Olejniczak et al., 2017).

4. Em que pese o reconhecimento da existência de diversas correntes de pensamento que trazem críticas ou construções alternativas aos pressupostos da abordagem racionalista, assim como das diferenças entre estas, adotamos para fins de facilitação de compreensão nesse estágio da pesquisa a terminologia construtivista, sugerida por Pinheiro (2020), para designar esse conjunto paradigmas. 
Estudos que exploram empiricamente o trabalho na política pública (Meltsner, 1976; Colebatch et al., 2010; Olejniczak et al., 2017) têm demonstrado, no entanto, que a função de análise de política pública, em geral, ocorre associada a outras funçôes, como as de tipo relacional. Revelam, ainda, uma diversidade de atividades realizadas na produção de políticas públicas, que vão além da função de pesquisa, análise, avaliação e recomendações, como funções de negociação intergovernamental, consultas públicas, tradução e até mesmo de democratização. Reconhece-se também nesse debate as diversas formas de conhecimento que são trazidas pelos diferentes atores que participam da política pública (Colebatch et al., 2010) e os produtos da interação da burocracia com esses atores (Cairney, 2019). Fatores esses que já vêm sendo explorados e reconhecidos na literatura nacional (Cavalcante e Lotta, 2015; Pires et al., 2018).

Diante do debate apresentado anteriormente, este estudo busca contribuir para ampliar o conhecimento sobre a função de análise de políticas públicas no contexto brasileiro, focando na exploração dos fatores e fontes que têm informado as políticas públicas no nível federal.

\subsection{Os estudos empíricos sobre o uso de evidências na análise de políticas públicas}

Duas frentes de estudos empíricos foram analisadas, com vistas a trazer aportes teóricos para a exploração da funçáo analítica do Estado brasileiro, ${ }^{5}$ bem como do que informa as políticas públicas no Brasil. A primeira frente traz estudos com foco na compreensão dos condicionantes do uso de evidências stricto sensu. Por sua vez, a segunda incorpora estudos que reconhecem as críticas a PPBEs e sugerem um modelo construtivista, adotando abordagem exploratória para mapear as fontes de informaçóes e conhecimentos utilizados pelas burocracias e os contextos de sua utilização.

Um dos primeiros estudos empíricos com alcance estatístico a respeito dos diferentes tipos de uso de evidências em políticas públicas foi desenvolvido por Amara, Ouimet e Landry em 1998 e publicado em 2004. Partindo da discussão teórica mencionada na subseção anterior, os autores sugerem três tipos possíveis de uso de evidências pelos

5. A função analítica corresponde à atividade de produção de estudos de políticas públicas sobre a qual a subseção 2.1 discorre. Como mencionado na subseção, embora tal função seja objeto de interesse considerável em outros países, no Brasil ainda é pouco discutida ou até mesmo reconhecida. Pouco se discute, por exemplo, que parte das capacidades essenciais do Estado brasileiro seria o acúmulo de recursos e habilidades para produção de análises e conhecimentos acerca dos processos de produção e dos conteúdos das políticas públicas.

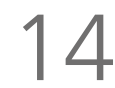


gestores (instrumental, conceitual e simbólico). ${ }^{6}$ Argumentando que pouquíssimos estudos empíricos haviam explorado aquela perspectiva, quase todos se resumindo a estudos de caso, propóem-se a realizar um amplo survey com os servidores das agências governamentais canadenses ${ }^{7}$ (Amara, Ouimet e Landry, 2004).

Um resultado importante encontrado pelos autores foi a constatação de que a maior ou menor presença de cada tipo de uso varia de acordo com a agência governamental em questáo - ou seja, o contexto organizacional é determinante, assim como, ao contrário do que a literatura defendia, o uso conceitual era mais presente do que o instrumental e o simbólico. Por sua vez, os resultados do survey indicavam que a produção de pesquisas focadas nas necessidades dos gestores, por um lado, e a formação/capacitação dos gestores para recepçáo das pesquisas, por outro, eram fatores fundamentais para o fortalecimento dos três tipos de usos (Amara, Ouimet e Landry, 2004).

Por sua vez, a despeito do entusiasmo de governos e pratictioners com os argumentos da PPBE, Vesely, Ochrana e Nekola (2018) enumeram as críticas e os desafios que a literatura tem destacado a esse movimento. Além das já mencionadas na subseção anterior, está o fato de conceder-se supremacia a evidências científicas na promoção de respostas objetivas a questóes inerentemente políticas.

Os autores argumentam que, se estamos interessados em compreender melhor o uso do conhecimento, devemos nos inclinar a estudar o uso de evidências em países que não têm sido influenciados por aquele movimento, e em que o uso de evidência não é tido automaticamente como a "coisa certa". Essa inclinação proposta é oportuna pelo fato de pesquisas sobre o uso de evidência ainda se concentrarem em casos nórdicos e anglo-saxōes, nos quais esse uso é esperado. E, nessa literatura mainstream, compreendem que três vertentes formam a estrutura conceitual básica para o estudo de PPBEs: i) atores e instituiçóes; ii) tipos de evidência e conhecimento comunicados entre esses atores; e iii) diferentes usos de evidência.

No entanto, Vesely et al. (2018) acrescentam que há o quarto aspecto estruturante faltante: o que os atores acreditam ser a evidência e qual papel designam para esta nas suas

6. Beyer (1997) define os três tipos da seguinte forma: instrumental (aplicação direta do conhecimento produzido); conceitual (uso das evidências para fins de esclarecimento e ampliação de discussões e perspectivas); e simbólico (evidências servem apenas como justificativa para decisões já tomadas).

7. Foram obtidas 833 respostas válidas. 
práticas diárias. Assim, permite-se assumir que o uso de evidência é processo dinâmico e que os atores têm seus próprios conceitos do que seja evidência.

No caso brasileiro, em pesquisa desenvolvida pela Enap (2018), identificou-se que os burocratas do serviço civil da administração federal direta baseiam seu trabalho na política pública em diversas fontes de informação. Entre estas, fontes normativas (normas jurídico-legais e recomendações de órgãos de controle), assim como fontes midiáticas (mídia tradicional, mídia social ou redes sociais), são as utilizadas de forma mais recorrentes, enquanto dados de monitoramento e avaliação de políticas públicas, bem como dados estatísticos ou surveys são fontes usadas de maneira menos frequente. Além disso, o relatório apontou que há associação significativa entre a função analítica de política pública exercida pelos burocratas e o atendimento às demandas de órgãos de controle. Portanto, torna-se uma questão quais os recursos informacionais mais influentes na burocracia federal e se o uso de evidências científicas, no caso brasileiro, seria trazido à burocracia produtora de políticas a partir de incentivos pela burocracia do controle. Diante dessa questão, sustentamos relevante observar tanto os burocratas produtores como os do controle.

Explorando de maneira mais analítica os dados coletados pela Enap, Macedo, Viana e Nascimento (2019) identificaram quais fontes de evidências são usadas pelos burocratas do serviço civil da administração federal brasileira, considerando-se: i) características demográficas da burocracia; ii) tipos de função na política pública; iii) diferentes órgãos da administração federal; iv) tipos de cargos na administração federal; e v) áreas de política pública. De maneira mais agregada, julgaram que o survey contemplava cinco tipos de fontes de informação: analítica, normativa, adviser, beneficiária e midiática.

Considerando-se a relação com o nível de instrução do servidor e a intensidade de recorrência a diferentes fontes de informação, o achado da pesquisa foi que quanto menor o nível de instrução, menor é a chance de recorrer-se a diversidades informacionais; além disso, quanto maior o tempo na política pública, menos diversa também se mostra a recorrência à diversidade de fontes informacionais. Isolando-se o tipo de cargo exercido, em média, servidores que exercem maiores cargos tendem a recorrer a diversas fontes de informação. Entre as funçôes de políticas públicas (relacional, analítica, gerencial e administrativa), a burocracia de função relacional foi a única que não recorre com muita ênfase às fontes de natureza normativa (Macedo et al., 2019). Além do mais, independentemente da área de política pública, os resultados trazidos pelos autores destacaram a recorrência da burocracia às fontes de natureza normativa. Portanto, são resultados que podem reforçar o questionamento sobre o papel da evidência científica 
e de outras fontes de informação na produção de políticas públicas no Brasil; parte do que será explorado neste estudo.

\subsection{Proposição de um modelo teórico-analítico}

Adotando a proposição trazida por Pinheiro (2020), sugerimos um modelo de posição moderada acerca da concepçáo de evidências. Isto é, reconhecemos tanto os pressupostos da abordagem racionalista instrumental da gênese dos estudos de análise de políticas públicas e do movimento das PPBEs, como contribuiçóes mais recentes aportadas pelas abordagens construtivistas que apontam para outros condicionantes da produção de políticas públicas, como já discutido. Ou seja, parte-se do entendimento de que não apenas as pesquisas e os estudos científicos informam as políticas públicas.

A figura 1 baseia-se na atualização da proposta feita por Ouimet et al. (2009), que enfatiza a chamada capacidade de absorção de evidências no âmbito do policy making. A ideia de capacidade de absorçáo é tomada emprestada da literatura de administração de empresas, inicialmente focando nas possibilidades de prospecção e internalização de conhecimento produzido no âmbito externo às organizaçôes. Essa dimensão macroconceitual dialoga diretamente com três perspectivas teóricas no campo: i) perspectiva racionalista; ii) perspectiva organizacional; e iii) perspectiva comunicativa.

A primeira perspectiva parte dos aspectos individuais de racionalidade que mobilizam os tomadores de decisão individualmente. Como referência mais ampla, parte-se do modelo da escolha racional, pressupondo a utilização de informação científica disponível para processamento de conhecimento científico válido. A não utilização de evidências, portanto, apontaria para falhas de racionalidade na atuação dos servidores públicos. A ênfase dessa abordagem está sobretudo na mensuração do acesso, inclusive de infraestrutura, ao conhecimento científico, tomado como um bem público - não rival e não excludente.

Em conjunto ao acesso físico, é relevante pensar no acesso cognitivo - ou seja, nas habilidades e competências necessárias para fazer uso do conhecimento produzido. Um aprofundamento dessa última característica aponta para a necessidade de refletir a respeito dos limites da racionalidade - na perspectiva da racionalidade limitada. Desse modo, características individuais como nível de escolaridade e treinamento em metodologia científica podem se apresentar como decisivas para absorção de conhecimento científico. 
O modelo proposto neste estudo considera essa primeira perspectiva proposta por Ouitmet et al. (2009), mas não se restringe a esta, ampliando a dimensão individual ao incorporar outros condicionantes apontados pelas abordagens construtivistas. Como retratado na figura 1 , além da capacidade analítica individual, identificada pelos conhecimentos, habilidades e experiência profissional prévia do burocrata, também são observados o tipo de trabalho executado e os valores e as motivaçóes como possíveis condicionantes do uso e da capacidade de absorção das evidências científicas pelos indivíduos.

A segunda perspectiva apontada por Ouimet et al. (2009) foca o nível organizacional. Organizaçóes são relevantes para catalisar ou dinamizar a utilização de evidências. Por um lado, encontram-se a organização de infraestrutura tecnológica para facilitar o acesso à produção científica, bem como a mobilização de recursos organizacionais para construir unidades administrativas de intermediação e interlocução com a academia, as chamadas policy units. Em muitos casos, são recrutados profissionais diretamente envolvidos com essa tarefa, em regra com background previamente ligado à produçáo de pesquisa científica. Por outro, há elementos internos que apontam para a existência de vieses ou seletividade - como a utilização mais frequente de evidências internas que externas -, assim como assumem preponderância fatores estratégicos ou políticos (op. cit.). Essa dimensão está retratada no modelo proposto, como a dimensão de capacidade analítica organizacional.

A terceira perspectiva aponta para um aprofundamento da perspectiva organizacional, com enfoque na relação entre academia e gestão pública ou serviço civil. Parte do pressuposto que se trata de duas comunidades distintas, com termos técnicos e jargóes particulares e que, de forma geral, almejam obter objetivos distintos. Há, portanto, um fosso entre essas comunidades, o que tornaria a comunicaçáo entre esses dois grupos uma necessidade fundamental para possibilitar a utilização ou absorção de conhecimento científico. Observa-se assim uma via de mão dupla: por um lado, a ênfase em aspectos individuais dos próprios servidores públicos, que devem possuir um mínimo de "alfabetização científica"; por outro, o destaque para aspectos da própria evidência - quanto à simplificação do linguajar, à definição clara dos resultados e à explicitação de recomendaçóes, por exemplo. Os distintos aspectos que envolvem essa perspectiva interacional entre Estado e academia estáo contemplados no modelo como interaçóes sociais, relaçôes de poder e atributos da evidência. 
FIGURA 1

Modelo analítico para exploração do uso de evidências (estudos e pesquisas científicas) na produção de políticas públicas

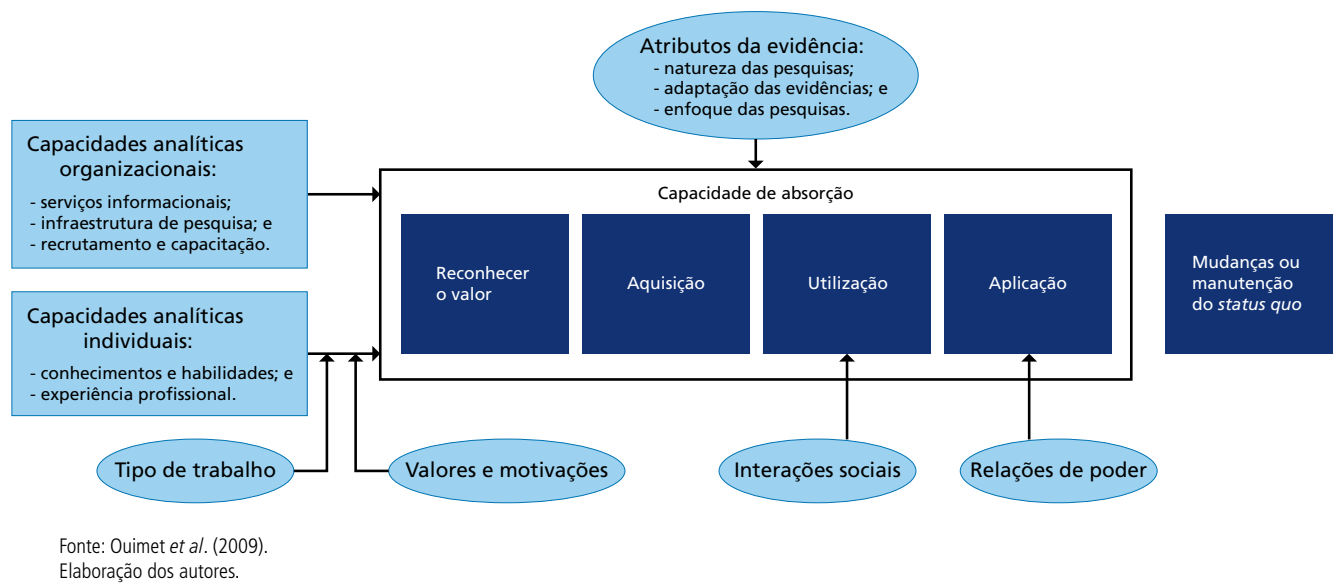

Vale esclarecer que, embora o modelo analítico retrate possíveis interações entre os distintos fatores apontados pela literatura discutida, este trabalho apresentará apenas resultados em grande parte descritivos concernentes a uma parte dessas variáveis. $\mathrm{O}$ modelo embasou a construção do instrumento survey que permitiu a coleta de dados acerca de boa parte das variáveis apresentadas, tais como níveis de capacidade, tipos de trabalho de política pública, valores e motivaçóes, interaçóes sociais, atributos das evidências etc. Contudo, outras variáveis - como as que integram a capacidade de absorção, as relações de poder e a mudança ou manutenção do status quo - não foram incorporadas no survey por entendermos ser de difícil percepção esse tipo de instrumento de coleta. No entanto, os dados apresentados neste estudo já permitem traçar um retrato importante das dimensóes do modelo contempladas no survey e serão explorados em pesquisas futuras a partir de cruzamentos e análises de inferências. Os próximos estágios da pesquisa também buscam analisar os fatores do modelo analítico que não puderam ser considerados neste estudo.

\section{METODOLOGIA}

Tendo-se em vista que os objetivos desta pesquisa consistiam em mapear as diversas fontes que informam as políticas públicas e compreender contextos e fatores relativos à utilização ou não de evidências científicas por parte da burocracia no Brasil, fez-se opção pela aplicação de um survey relativo aos servidores da administraçáo pública federal $(\mathrm{APF})$, em razão de sua potencialidade para captar práticas, atitudes e percepções com representatividade estatística. 
Assim, a coleta de dados ocorreu por meio da aplicação de questionário autoadministrado on-line (plataforma LimeSurvey), enviado por e-mail a uma amostra previamente selecionada do público-alvo da pesquisa - os detalhes da amostragem serão discutidos na subseção 3.2 .

Ao longo de seis sessóes temáticas, o questionário apresentado procurava identificar:

- perfil funcional dos respondentes, mapeando o tipo de vínculo com a administraçáo, a carreira, o ministério de lotação, entre outros exemplos;

- sua área de atuação no campo da política pública;

- as principais atividades e funçóes desempenhadas no dia a dia do trabalho;

- padrôes de acesso e utilização de diferentes tipos de informação -com foco no que aqui designamos como evidências científicas -, contextos individuais e organizacionais que condicionam os usos e os não usos dessas informaçoes, entre outros aspectos;

- conhecimentos, habilidades e valores dos respondentes; e

- perfil sociodemográfico (sexo, raça/etnia, escolaridade etc.).

\subsection{Construção do questionário}

O questionário aplicado foi desenhado fundamentalmente com base nas variáveis propostas no modelo analítico descrito na figura 1 . Todo o processo de elaboração se estendeu entre julho e outubro de 2019, envolvendo quatro etapas:

- tradução e adaptação para o contexto brasileiro de questionários utilizados por pesquisadores estrangeiros (Ouimet et al., 2009; Cherney et al., 2015; Veselý, Ochrana e Nekola, 2018);

- revisão metodológica durante oficina com especialista em surveys e demais parceiros do projeto de pesquisa;

- aplicação presencial de questionário-piloto com grupo náo representativo e não aleatório de servidores; e

- pré-teste on-line com trinta servidores de diferentes perfis.

$\mathrm{Na}$ primeira fase, foi levantado um grande número de publicaçóes e pesquisas desenvolvidas por pesquisadores de diferentes países sobre o uso de evidências científicas na administração pública. Para as pesquisas que pareceram mais relevantes ou próximas à realidade brasileira, foram feitas tentativas no sentido de acessar os questionários originais e traduzi-los para o português. A partir disso, realizou-se, entáo, uma seleção das questóes mais interessantes/importantes que poderiam ser adaptadas ao contexto brasileiro 
e incorporadas neste survey. As principais contribuiçôes foram retiradas das pesquisas de Ouimet et al. (2009), Cherney et al. (2015) e Veselý, Ochrana e Nekola (2018).

Para a segunda fase, foi contratada uma oficina ${ }^{8}$ sob medida, ministrada por professor-pesquisador de reconhecida formação na construção de survey, com o objetivo de auxiliar no aprimoramento metodológico do instrumento. Diversos integrantes da rede institucional vinculada ao projeto de pesquisa também colaboraram com os trabalhos da oficina (servidores do Ipea, da Enap e da Codeplan-DF, bem como pesquisadores do IDS no Reino Unido).

$\mathrm{Na}$ terceira fase, uma versão piloto do questionário foi aplicada presencialmente em um pequeno número de servidores públicos federais lotados em diferentes ministérios. As aplicaçóes foram feitas de forma individual, com o pesquisador lendo o questionário para o pesquisado, de modo que ele pudesse simultaneamente responder às questóes e avaliá-las, comentando aspectos como clareza e pertinência do conteúdo, tempo de resposta, lógica e disposição das seçôes etc.

$\mathrm{Na}$ quarta e última fase, foi realizado um pré-teste on-line com um grupo não representativo e não aleatório de trinta servidores públicos federais. Além de responder a todas as questôes na plataforma virtual, testando a qualidade e a operacionalidade da interface, esse grupo também foi convidado a tecer comentários, críticas e sugestôes.

Todos esses procedimentos foram levados em consideração na versão final do questionário aplicado, de modo a maximizar a aderência do instrumento à realidade da burocracia federal.

\subsection{Amostragem, coleta e análise de dados}

O processo de amostragem para este survey teve de lidar com um impedimento técnico decisivo, que foi a indisponibilidade dos dados atualizados relativos à unidade de lotação e contato de e-mail dos servidores da APF para 2019.

Desse modo, fez-se opção por utilizar exatamente a mesma amostra selecionada em survey anterior da Enap sobre o serviço civil no Brasil (Enap, 2018). Por um lado, a utilizaçáo da amostra anterior solucionou a questão da falta dos dados - sobretudo,

8. A oficina Construção de Questionários, Aplicação de Pré-Testes e Experimentos de Survey foi realizada entre 19 e 21 de agosto de 2019, sob coordenação do pesquisador Alessandro Freire, da Universidade de Brasília (UnB). 
os de contato - dos servidores, indispensáveis para a realização da pesquisa. Também permitiu algum grau de comparabilidade entre resultados dos dois surveys, visto que algumas perguntas do survey de 2017 foram replicadas neste estudo. Contudo, entretanto, implicou obstáculos técnicos importantes. Em primeiro lugar, o fato de os dados de contato datarem de 2017 criou uma defasagem importante no acesso aos servidores. Em segundo lugar, os parâmetros da amostragem de 2017 (número total do universo, mudanças na sua composição - com indivíduos entrando e saindo do serviço civil -, mudanças na distribuição desse total entre os ministérios etc.) foram significativamente alterados ao longo de dois anos, principalmente com a entrada de um novo governo em janeiro de 2019. Ainda assim, decidiu-se pela utilização da amostra anterior por ser a única solução possível para a realização deste survey.

$\mathrm{Na}$ ocasião da pesquisa de 2017 , a seleção da amostra a partir de um universo de 96.543 servidores civis da administração direta foi realizada por meio da técnica de estratificação simples. ${ }^{10} \mathrm{Ou}$ seja, uma quantidade previamente estabelecida de servidores foi selecionada - por sorteio - para cada um dos 24 órgãos da administração direta existentes na base do Sistema Integrado de Administração de Pessoal (Siape) em 2017 para maiores detalhes da composição estratificada, conferir Enap (2018).

A primeira amostra escolhida continha 6.055 servidores. Foram então realizadas mais duas rodadas de seleção utilizando exatamente o mesmo método, chegando ao número final de 18.165 servidores escolhidos. Esses servidores foram convidados para participar deste survey em 2019.

Sobre a coleta de dados, o questionário foi publicado em 23 de outubro de 2019 e encaminhado por e-mail para todos os 18.165 servidores da amostra. Lembretes semanais foram enviados para que a taxa de resposta fosse satisfatória. O questionário foi disponibilizado inicialmente por trinta dias, com extensão de prazo de três semanas, o que totalizou cinquenta dias. Desse modo, a coleta foi encerrada em 10 de dezembro de 2019.

9. Com base no índice de retorno dos e-mails - por motivos como não existência do e-mail de destino -, foi possível estimar que em torno de 7,5\% dos servidores da amostra não receberam o convite para o questionário por conta da defasagem temporal dos dados.

10. Esse método consiste em subdividir as populações em subpopulações (estratos). Em seguida, seleciona-se uma amostra aleatória simples de cada estrato. 0 tamanho da amostra a ser retirada dos estratos depende de vários fatores, quais sejam: i) tamanho do estrato; ii) homogeneidade dos elementos em cada estrato; iii) custo de escolher cada unidade por estrato; e iv) a importância das estimativas para os diferentes estratos. 
Ao fim da coleta, foram obtidos 2.292 registros completos válidos - ou seja, quando o respondente preencheu o questionário até o fim e confirmou o envio das respostas. O que representa uma taxa de resposta de $11,66 \%$. Contudo, como parte dos respondentes não preenchia todos os pré-requisitos como público-alvo da pesquisa (aposentados, servidores cedidos para outros poderes ou instâncias etc.), o número final de casos na base de dados foi de 2.180 .

Em seguida, foram analisados os missing values (dados ausentes) e os outliers (dados atípicos) da base, com o propósito de identificar e corrigir eventuais erros, o que não afetou o número total de casos válidos. $\mathrm{Na}$ ocasião, também foi feita a categorização das respostas relativas às perguntas abertas, de modo a ampliar a validade do padrão de respostas do survey.

As análises descritivas apresentadas na próxima subseção, em geral, levaram em consideração dados de médias, desvios-padrão, percentuais e frequências de respostas. Em uma pequena parte dos dados, também foi realizada a técnica exploratória de análise fatorial. ${ }^{11}$ Para realização das análises, foram utilizados os softwares estatísticos RStudio, SPSS e Excel. ${ }^{12}$

\subsection{Survey da Enap sobre serviço civil (2017)}

Como dito, não apenas esta pesquisa foi proposta a partir dos resultados encontrados em survey a respeito do serviço civil no Brasil realizado pela Enap em 2017, como também a amostra selecionada foi replicada deste. Além disso, algumas perguntas apresentadas no questionário atual também foram reproduzidas ou adaptadas a partir do survey de 2017.

Desse modo, convém sublinhar as especificidades do estudo anterior com relação ao atual. Em primeiro lugar, a pesquisa realizada pela Enap tinha como objetivo mapear funçôes e capacidades de produção de políticas públicas por parte do serviço civil federal. Dessa forma, o survey anterior procurava dar conta do quadro geral no que tange a:

11. A análise fatorial é uma técnica estatística baseada no pressuposto de que uma série de variáveis observadas, chamadas de variáveis empíricas, pode ser explicada por um número menor de variáveis hipotéticas, não observáveis, chamadas de fatores (Pasquali, 2001).

12. Como recomendações para futuras análises, argumenta-se pela necessidade de uma nova onda de survey para lidar com duas limitações deste survey: a primeira objetiva superar os empecilhos para uma amostra atualizada de respondentes, a partir dos contatos dos servidores públicos federais atualmente na ativa; a segunda, de natureza substantiva, visa à aplicação de técnicas de experimento de survey para diminuir a desejabilidade social de respostas "favoráveis" ao uso de evidências científicas, o que possibilitaria obter respostas com maior grau de confiabilidade. 
trabalho e funções desempenhadas pelos servidores nas políticas públicas; conhecimentos, habilidades, valores e motivações dos servidores; recursos informacionais, interacionais e contexto relacional da política pública; entre outros exemplos.

Por sua vez, esta pesquisa tem como foco principal a questão da utilização de conhecimentos e informaçôes pelos servidores no âmbito do seu trabalho com políticas públicas. Nesse sentido, procura mapear aspectos bem mais específicos como: fontes e tipos de informação utilizados pelos servidores; condicionantes individuais e organizacionais da utilização de evidências; tipos de usos e fatores que destacam as evidências utilizadas; entre outros.

Com relação ao questionário aplicado, muitas das questôes sobre perfil funcional, área de atuação na política pública, atividades e funções desempenhadas, bem como perfil sociodemográfico, foram reproduzidas ou adaptadas a partir do survey anterior. Contudo, quase toda a seção sobre utilização de informações e evidências foi construída no âmbito da pesquisa atual - a partir de adaptaçôes de estudos internacionais ou até mesmo questóes inéditas.

\subsection{Caracterização do universo}

Embora a amostra selecionada para esta pesquisa tenha sido replicada a partir do survey de 2017 da Enap, todo o processo de coleta de dados, bem como os resultados e as conclusóes que serão apresentados aqui, diz respeito a 2019. Dessa forma, a caracterização do universo populacional da pesquisa deve necessariamente corresponder a esse ano.

Os dados a seguir foram extraídos do Painel Estatístico de Pessoal do Ministério da Economia (ME) e correspondem à situação da administração direta federal em dezembro de 2019. ${ }^{13}$

No que diz respeito ao perfil sociodemográfico dos servidores, há preponderância do sexo masculino $(56,7 \%)$ com relação ao sexo feminino $(43,3 \%)$.

13. Como não houve disponibilização da base de dados do Siape, recorreu-se ao painel para obter algumas informações gerais sobre o universo pesquisado. Por conta de limitações da própria ferramenta, não foi possível desagregar os dados somente para o serviço civil. 


\section{GRÁFICO 1}

Sexo dos servidores

(Em \%)

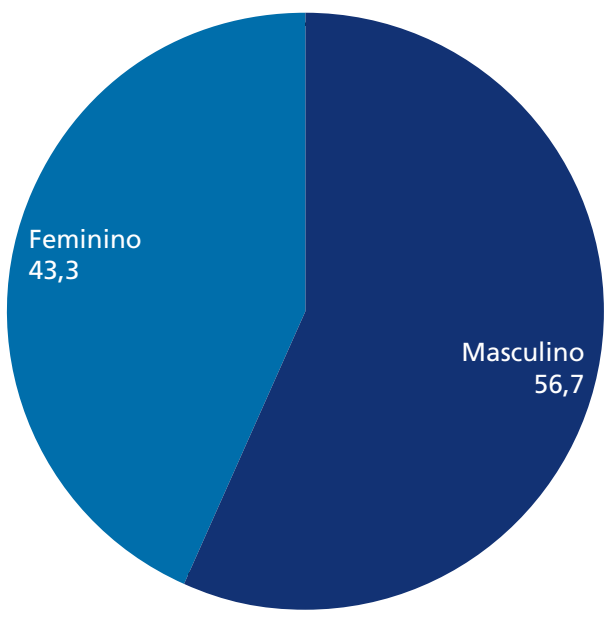

Fonte: ME.

Elaboração dos autores.

Com relação à faixa etária dos servidores, a média de idade dos integrantes da administração direta federal é de 48 anos. A distribuição entre as faixas etárias pode ser observada no gráfico 2. Nota-se que o maior grupo possui entre 51 e 60 anos $(27,56 \%)$, seguido pelos grupos entre 31 e 40 anos (22,08\%) e 41 e 50 anos (20,29\%).

GRÁFICO 2

Faixa etária dos servidores

(Em \%)

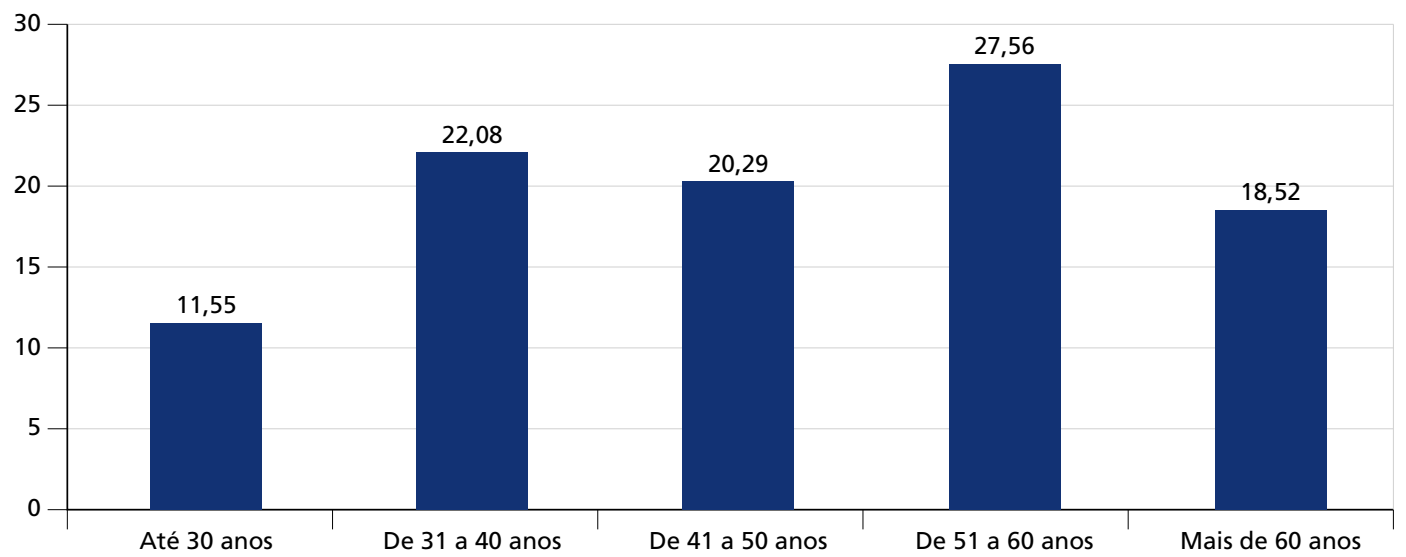

Fonte: ME.

Elaboração dos autores. 
No que diz respeito ao nível de escolaridade (gráfico 3), pode-se observar que a maioria dos servidores possui alguma graduação de nível superior (60,98\%). Em seguida, os servidores com ensino médio ou técnico correspondem a 24,35\%. Os servidores com ensino fundamental, por sua vez, são $7,75 \%$ do total. Finalmente, há os servidores com especialização (4,19\%), mestrado (1,56\%) e doutorado (1,17\%).

\section{GRÁFICO 3}

Nível de escolaridade dos servidores

(Em \%)

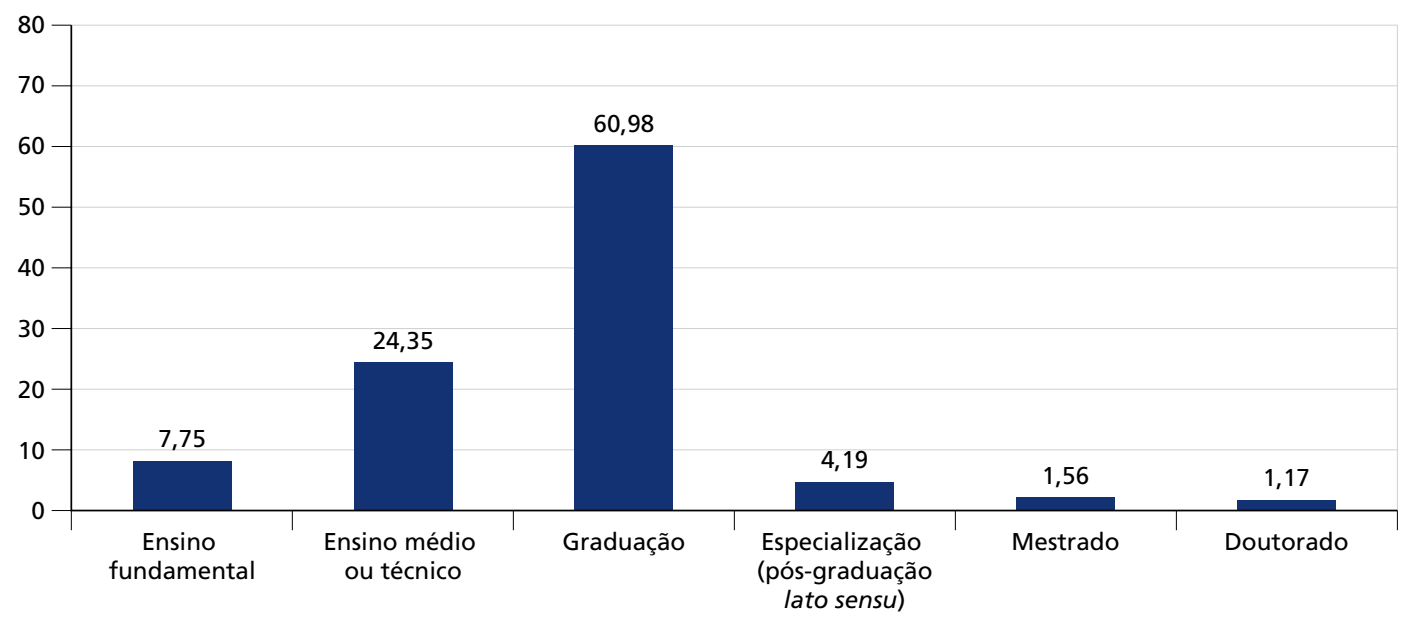

Fonte: ME.

Elaboração dos autores.

No tocante à ocupação dos cargos de confiança e funções gratificadas, apenas 14\% dos servidores da administração direta federal possuíam algum dos dois em dezembro de 2019. Os servidores com comissôes de direção e assessoramento - como de direção e assessoramento superior (DAS) e de funçôes comissionadas técnicas do Poder Executivo (FCPE) - correspondiam a apenas $7 \%$ do total. $\mathrm{O}$ mesmo percentual de servidores recebia alguma funçấo gratificada ou técnica. 


\section{GRÁFICO 4}

Cargos de confiança e funções gratificadas dos servidores (Em \%)

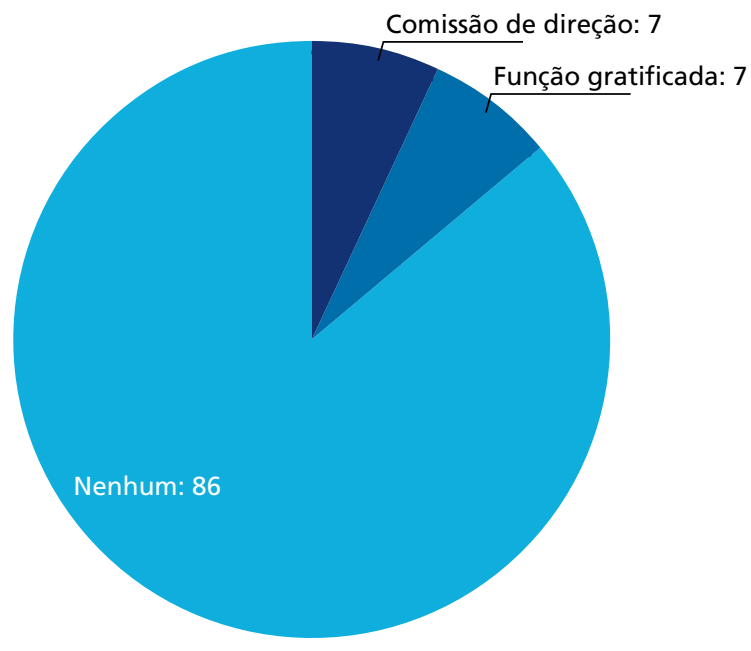

Fonte: ME.

Elaboração dos autores.

\section{RESULTADOS}

Ao longo desta seção, serão apresentados os principais resultados obtidos por meio do survey, com base nos 2.180 questionários válidos. Para melhor disposição, os dados estão subdivididos em cinco subseções temáticas.

A primeira, Perfil funcional, apresenta os dados relativos à condição profissional dos respondentes, como o tipo de vínculo com a administração, a carreira atual, o ministério em que está lotado, assim como os dados concernentes ao perfil sociodemográfico dos respondentes.

A segunda subseção, Trabalho e funçóes de politicas públicas, aborda as respostas relativas às rotinas de trabalho e às funçóes desempenhadas pelos respondentes no âmbito das políticas públicas, considerando aspectos como área e política específica de atuação, tempo de atuação, principais atividades e funções exercidas no dia a dia etc.

A terceira subseção, Uso de informaçóes e evidências, traz os resultados de maior interesse para este survey - ou seja, os padrôes de acesso e utilização de diferentes tipos de informação, bem como fatores individuais e organizacionais que impactam nos usos e não usos de evidências científicas. Assim, são apresentados dados como tipos de 
informação mais utilizados, uso de pesquisas científicas no trabalho, fontes de obtenção de evidências, entre muitos outros.

A quarta subseção, Habilidades e valores, trata das respostas obtidas sobre aspectos individuais e formativos dos respondentes que podem ter algum impacto sobre a utilização de evidências, como a capacidade de realizar determinadas tarefas e a realização de cursos de formação.

Acredita-se que, ao fim, o panorama construído com os principais dados obtidos no survey permite compreender a realidade atual da utilização de diferentes fontes de informações e, sobretudo, estudos e pesquisas científicas, por parte dos servidores públicos federais no seu trabalho com políticas públicas.

\subsection{Perfil funcional e sociodemográfico}

Nesta subseção, serão apresentados os dados sobre o perfil profissional dos respondentes, de modo a delimitar desde já as principais características do grupo de burocratas que participou da pesquisa. Assim, serão abordadas variáveis como: o tipo de vínculo com a APF; carreira à qual pertence; órgão/ministério no qual trabalha; cargo em comissão ocupado e nível deste; etc.

No que diz respeito à primeira variável analisada, o vínculo do respondente com a administraçâo pública federal, verifica-se que a grande maioria dos participantes é composta de servidores públicos efetivos (93,7\%). Na segunda posição, em quantidade bem menor, têm-se os burocratas sem vínculo efetivo (ocupantes de cargos em comissão), com 5,6\%. Os demais tipos de vínculo (aposentado, requisitado de outros poderes e empregado público) obtiveram percentuais próximos a 0 .

TABELA 1

Vínculo do servidor com a administração pública federal

\begin{tabular}{|c|c|c|}
\hline Tipo de vínculo & Número & $\begin{array}{c}\text { Simples } \\
(\%)\end{array}$ \\
\hline Servidor(a) público(a) efetivo(a) & 2.043 & 93,7 \\
\hline Sem vínculo (cargo em comissão) & 122 & 5,6 \\
\hline Aposentado(a) pela administração pública federal' & 5 & 0,2 \\
\hline Requisitado(a) de outros poderes e/ou esferas' & 4 & 0,2 \\
\hline Empregado(a) público(a) (empresas públicas)' & 6 & 0,3 \\
\hline Total & 2.180 & 100 \\
\hline \multicolumn{3}{|c|}{$\begin{array}{l}\text { Fonte: Ipea. } \\
\text { Elaboração dos autores. } \\
\text { Nota: 'Aposentados, requisitados de outros poderes e empregados públicos foram computados apenas como casos válidos quando estes ocupavam algum tipo de função } \\
\text { comissionada na APF direta. }\end{array}$} \\
\hline
\end{tabular}


Em relação à variável carreira atual, vale sublinhar que a pergunta somente foi apresentada aos respondentes que marcaram as opçóes 1 - Servidor(a) público(a) efetivo(a) ou 5 - Empregado(a) público(a) na primeira questão (vínculo com a APF).

Como no survey anterior sobre serviço civil (Enap, 2018), os dados encontrados demonstram mais uma vez a diversidade e a heterogeneidade de carreiras existentes na APF e na produção de políticas públicas (tabela 2). Carreiras de caráter administrativo dividem espaço com cargos específicos de auditor e analista - com suas respectivas funçôes de controle, análise e gestáo.

TABELA 2

Carreira atual do servidor: vinte mais recorrentes

\begin{tabular}{|c|c|c|c|}
\hline Nome da carreira & Número & $\begin{array}{l}\text { Simples } \\
(\%)\end{array}$ & $\begin{array}{l}\text { Válido } \\
(\%)\end{array}$ \\
\hline Agente administrativo & 188 & 8,6 & 9,7 \\
\hline Auditor federal de finanças e controle & 115 & 5,3 & 5,9 \\
\hline Analista ambiental & 95 & 4,4 & 4,9 \\
\hline Analista técnico de políticas sociais & 90 & 4,1 & 4,6 \\
\hline Analista técnico-administrativo & 89 & 4,1 & 4,6 \\
\hline Outros cargos de nível superior & 70 & 3,2 & 3,6 \\
\hline Especialista em políticas públicas e gestão governamental & 66 & 3 & 3,4 \\
\hline Analista de comércio exterior & 64 & 2,9 & 3,3 \\
\hline Tecnologista (desenvolvimento tecnológico) & 63 & 2,9 & 3,2 \\
\hline $\begin{array}{l}\text { Auditor fiscal federal agropecuário - funcionário do Ministério da Agricultura, Pecuária e } \\
\text { Abastecimento (Mapa) }\end{array}$ & 52 & 2,4 & 2,7 \\
\hline Analista de infraestrutura & 51 & 2,3 & 2,6 \\
\hline Diplomata & 51 & 2,3 & 2,6 \\
\hline Auditor fiscal do trabalho & 48 & 2,2 & 2,5 \\
\hline Auditor fiscal da Receita Federal do Brasil (RFB) & 47 & 2,2 & 2,4 \\
\hline Analista em ciência e tecnologia (C\&T) & 38 & 1,7 & 2 \\
\hline Outros cargos técnicos de nível médio & 37 & 1,7 & 1,9 \\
\hline Outros & 37 & 1,7 & 1,9 \\
\hline Pesquisador (pesquisa em C\&T) & 36 & 1,7 & 1,9 \\
\hline Cargos de nível intermediário do Plano Geral de Cargos do Poder Executivo (PGPE) & 33 & 1,5 & 1,7 \\
\hline Outros cargos técnicos de nível superior & 33 & 1,5 & 1,7 \\
\hline
\end{tabular}

Fonte: Ipea.

Elaboração dos autores.

Assim, logo de início, é preciso destacar a recorrência das carreiras específicas de analista ao longo de toda a lista. Além dos cargos de analista ambiental e analista técnico de politicas sociais, que ocupam respectivamente o terceiro e o quarto lugar da lista, com 
4,9\% (95) e 4,6\% (90) das observaçôes, outras quatro carreiras aparecem na lista: analista de comércio exterior; analista de infraestrutura; analista em ciência e tecnologia; e especialista em políticas públicas e gestão governamental. Ao todo, essas seis carreiras correspondem a 20,8\% (404) dos servidores públicos efetivos. Essa presença significativa poderia ser vista como um indicativo de que as funçóes de análise e assessoramento governamental, ao menos em tese, fazem parte do funcionalismo público federal.

Na sequência, encontram-se as carreiras de caráter administrativo, cumprindo funçóes tipicamente da área-meio das organizaçóes. Os cargos de agente administrativo e analista técnico-administrativo destacam-se, ocupando respectivamente o primeiro e quinto lugar da lista, com 9,7\% (188) e 4,6\% (89) dos respondentes. Como será sublinhado na subseção 4.2, a análise fatorial sobre atividades desempenhadas também reitera a presença de número relevante de respondentes com perfil administrativo.

Finalmente, chama atenção não somente o segundo lugar ocupado pela carreira de auditor federal de finanças e controle, com 5,9\% (115) das observaçóes, mas também a presença recorrente dos cargos de auditoria. Desse modo, as carreiras de auditor federal de finanças e controle, auditor fiscal federal agropecuário, auditor fiscal do trabalho e auditor fiscal da RFB somadas correspondem a 14\% do quadro obtido, com 262 respondentes. Ou seja, as carreiras de "controle" também surgem como as mais presentes no quadro de participantes.

A pergunta subsequente, Há quantos anos você faz parte desta carreira?, também foi apresentada apenas a servidores efetivos e empregados públicos. Para essa variável, o número total de respostas válidas foi de 1.959.

Como disposto no box 1, a média encontrada foi de quinze anos de carreira. $\mathrm{Na}$ subseção 4.2, esse dado será reiterado pela variável tempo de atuação na política pública. Juntos, estes evidenciam que a maioria dos burocratas pesquisados possui uma longa experiência no serviço público.

BOX 1

Tempo médio na carreira

A média de anos na respectiva carreira é de quinze anos, consideradas 1.959 respostas para a questão.

Elaboração dos autores.

Duas variáveis sobre perfil funcional contemplam a situação dos cargos de DAS e funçóes comissionadas equivalentes. Na primeira questão, o respondente foi perguntado 
se ocupa algum cargo de comissão. Como se pode ver no gráfico 5, grande parte afirmou que não ocupa nenhuma função comissionada (71\%).

Ainda assim, um número considerado alto afirmou que sim (29\%). Tudo indica que muitos participantes responderam sim porque recebem algum tipo de tipo de função gratificada ou técnica, o que não quer dizer que efetivamente ocupem cargo de DAS. ${ }^{14}, 15$

\section{GRÁFICO 5}

Ocupa algum cargo de DAS ou equivalente

(Em \%)

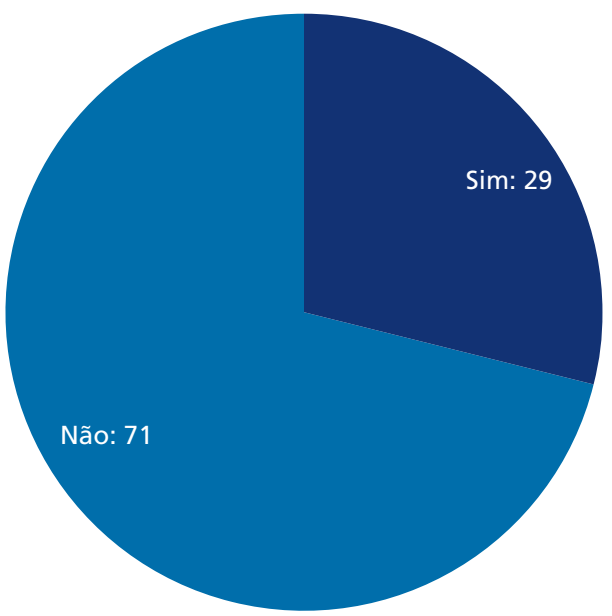

Fonte: Ipea.

Elaboração dos autores.

Aos respondentes que afirmaram ocupar cargo em comissão, foi apresentada a questão Qual o nivel do cargo de DAS ou equivalente que você ocupa atualmente?. Os dados obtidos estão dispostos no gráfico 6 . A grande maioria das respostas corresponde aos cargos DAS-4, DAS-3, DAS-2, FCPE-3 e FCPE-2, que são funçóes intermediárias e entre as mais comuns na administração direta federal.

14. Segundo o Painel Estatístico de Pessoal, cerca de 7\% dos servidores da administração direta federal ocupavam cargos de DAS ou equivalentes em dezembro de 2019. Contudo, existe percentual equivalente (também 7\%) de servidores que recebem funções gratificadas ou técnicas, mas que não necessariamente ocupam cargos de direção. É possível que o índice elevado obtido na variável advenha do fato de que tanto servidores com cargos de direção quanto servidores com função gratificada tenham respondido sim.

15. A confusão dos respondentes entre comissões de direção e assessoramento e funções e gratificações técnicas foi notada por meio das observações registradas na opção outros dessa questão. Muitos respondentes inseriram funções e gratificações técnicas como se fossem comissões de direção. 
GRÁFICO 6

Nível do cargo de DAS ou equivalente

(Em \%)

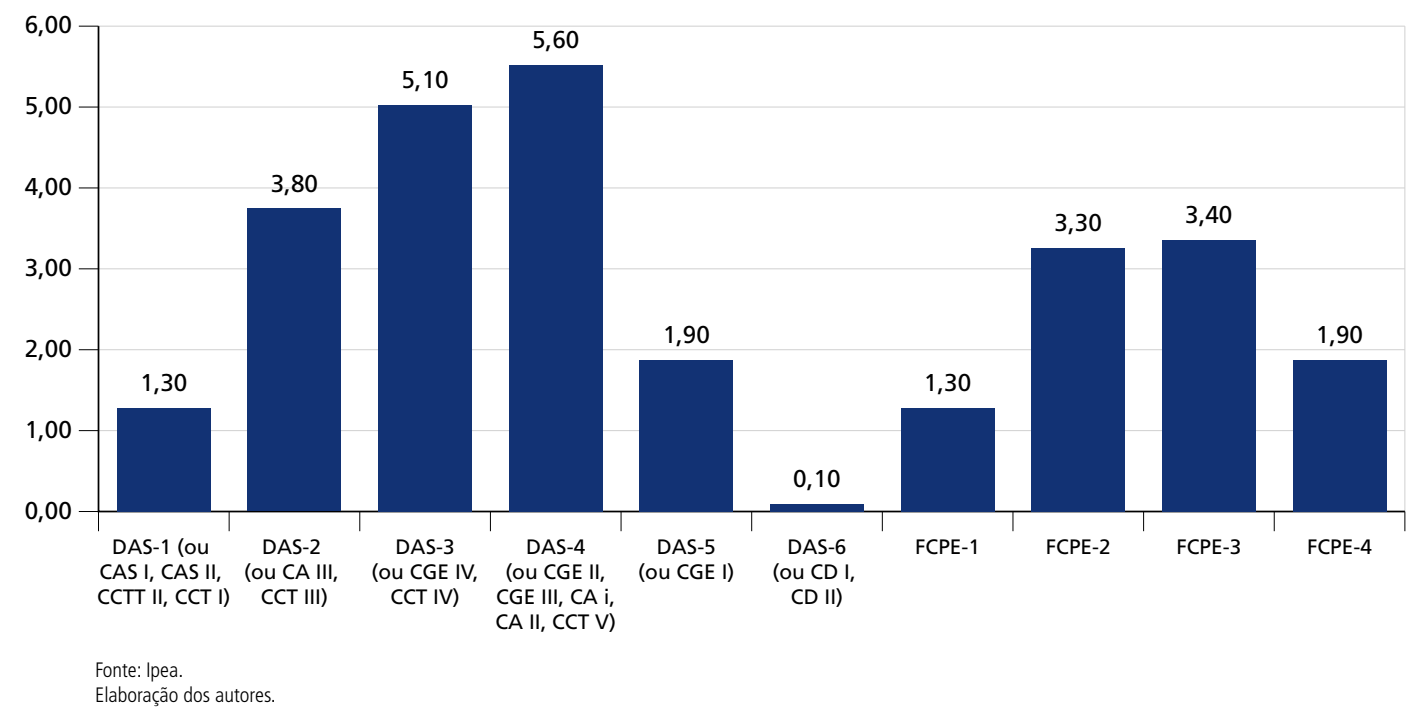

A penúltima variável do perfil contempla a distribuição dos respondentes por órgão de lotação (tabela 3). Em primeiro lugar da lista, com o maior número de participantes, encontra-se o Ministério da Economia: 23,7\% (513) das observações. ${ }^{16}$ Em seguida, o Ministério da Cidadania e o Ministério da Ciência, Tecnologia, Inovaçóes e Comunicaçôes (MCTIC) aparecem com 9,4\% (203) e 9,1\% (197). Ocupando o quarto lugar, com 7,8\% (168), está o Ministério da Agricultura, Pecuária e Abastecimento. Finalmente, chama atenção a presença da Controladoria-Geral da União (CGU) no quinto lugar da lista, com 6\% (129) dos respondentes.

TABELA 3

Ministério ou órgão superior em que o servidor trabalha

\begin{tabular}{lcc}
\hline Ministério/órgão superior & Número & $\begin{array}{c}\text { Válido } \\
(\%)\end{array}$ \\
\hline Ministério da Economia & 513 & 23,7 \\
Ministério da Cidadania & 203 & 9,4 \\
Ministério da Ciência, Tecnologia, Inovações e Comunicações & 197 & 9,1 \\
Ministério da Agricultura, Pecuária e Abastecimento & 168 & 7,8 \\
Controladoria-Geral da União & 129 & 6 \\
Ministério do Meio Ambiente & 108 & 5 \\
\hline
\end{tabular}

16. 0 elevado índice de repostas registrado para o ME condiz com o quadro atual do órgão, que conta com o maior número de servidores na Esplanada: em torno de 53 mil, em dezembro de 2019 (Brasil, 2019). 


\section{Discussão}

26190 Que Informa as Políticas Públicas: survey sobre o uso e o não uso de evidências pela burocracia federal brasileira

(Continuação)

\begin{tabular}{lcc}
\hline Ministério/órgão superior & Número & $\begin{array}{c}\text { Válido } \\
\text { (\%) }\end{array}$ \\
\hline Ministério da Saúde & 105 & 4,8 \\
Ministério das Relações Exteriores & 103 & 4,8 \\
Ministério da Educação & 99 & 4,6 \\
Ministério do Desenvolvimento Regional & 98 & 4,5 \\
Ministério da Justiça e Segurança Pública & 95 & 4,4 \\
Ministério da Defesa & 84 & 3,9 \\
Ministério da Infraestrutura & 75 & 3,5 \\
Ministério de Minas e Energia & 60 & 2,8 \\
Ministério do Turismo & 29 & 1,3 \\
Secretaria-Geral da Presidência da República & 20 & 0,9 \\
Ministério da Mulher, da Família e dos Direitos Humanos & 19 & 0,9 \\
Advocacia-Geral da União & 19 & 0,9 \\
Casa Civil da Presidência da República & 19 & 0,9 \\
Gabinete de Segurança Institucional da Presidência da República & 13 & 0,6 \\
Secretaria de Governo da Presidência da República & 06 & 0,3 \\
Gabinete Pessoal do Presidente da República & 05 & 0,2 \\
\hline
\end{tabular}

Fonte: Ipea.

Elaboração dos autores.

Por fim, a última variável do perfil funcional diz respeito à Unidade da Federação (UF) em que os respondentes trabalham. Apesar da já esperada concentração no Distrito Federal (DF), com 63\% (1347) dos participantes, houve um número significativo de respondentes de outras UFs em que há maior concentração de servidores federais: 194 (9\%) no Rio de Janeiro, 131 (6\%) em São Paulo, 64 (3\%) em Minas Gerais. Os demais estáo distribuídos da seguinte forma entre as UFs.

TABELA 4

Unidade da Federação em que o servidor trabalha

\begin{tabular}{|c|c|c|c|}
\hline UF & Número & $\begin{array}{c}\text { Válido } \\
(\%)\end{array}$ & \\
\hline Distrito Federal (DF) & 1.347 & 63 & \\
\hline Rio de Janeiro (RJ) & 194 & 9 & \\
\hline São Paulo (SP) & 131 & 6 & \\
\hline Minas Gerais (MG) & 64 & 3 & \\
\hline Paraná (PR) & 47 & 2 & \\
\hline Rio Grande do Sul (RS) & 36 & 2 & \\
\hline Bahia (BA) & 34 & 2 & \\
\hline Pará (PA) & 29 & 1 & \\
\hline Amazonas (AM) & 28 & 1 & \\
\hline Ceará (CE) & 27 & 1 & \\
\hline \multirow[t]{2}{*}{ Rio Grande do Norte (RN) } & 26 & 1 & \\
\hline & & & (Continuação \\
\hline
\end{tabular}




\begin{tabular}{lcc} 
(Continuação) & Número & Válido \\
\hline UF & 25 & 1 \\
\hline Pernambuco (PE) & 24 & 1 \\
Santa Catarina (SC) & 22 & 1 \\
Goiás (GO) & 20 & 1 \\
Mato Grosso do Sul (MS) & 16 & 1 \\
Rondônia (RO) & 13 & 1 \\
Espírito Santo (ES) & 11 & 1 \\
Maranhão (MA) & 8 & 0 \\
Alagoas (AL) & 8 & 0 \\
Paraíba (PB) & 7 & 0 \\
Mato Grosso (MT) & 5 & 0 \\
Sergipe (SE) & 5 & 0 \\
Tocantins (TO) & 4 & 0 \\
Roraima (RR) & 3 & 0 \\
Amapá (AP) & 2 & 0 \\
Piauí (PI) & 2 & 0 \\
Acre (AC) & 1 & 1 \\
\hline
\end{tabular}

Fonte: Ipea.

Elaboração dos autores.

Com relação ao perfil sociodemográfico dos servidores, seguindo a distribuição do próprio universo da administração direta federal, a maior parte dos respondentes reconheceu-se como do sexo masculino; $60 \%$ dos participantes para $40 \%$ do sexo feminino.

GRÁFICO 7

Sexo do servidor

(Em \%)

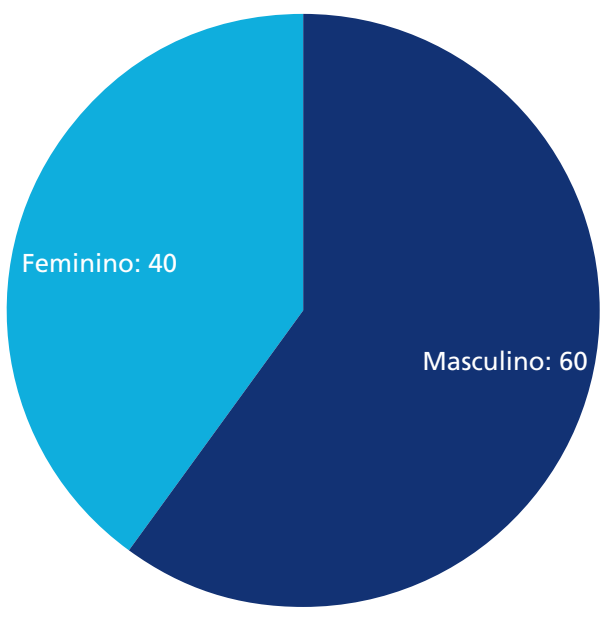

Fonte: Ipea.

Elaboração dos autores. 
A média de idade dos respondentes, por sua vez, foi de 46 anos.

A variável raçalcorletnia evidencia, como em outros estudos, discrepância entre os quadros do campo burocrático e a sociedade brasileira como um todo. $61,83 \%$ dos servidores autodeclararam-se como brancos, enquanto $29,77 \%$ afirmaram que eram pardos e somente $6,12 \%$ se autodeclararam negros. O número de indígenas é ainda menor $(0,33 \%)$.

\section{GRÁFICO 8}

Raça do servidor

(Em \%)

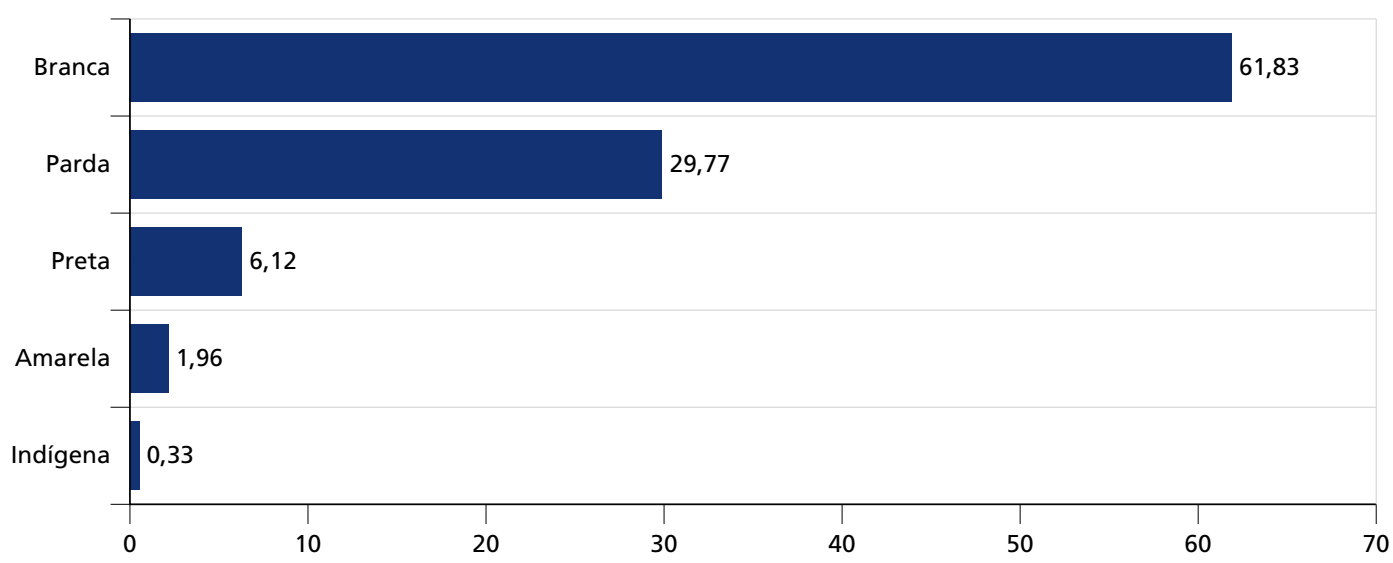

Fonte: Ipea.

Elaboração dos autores.

No que diz respeito ao nivel de escolaridade (gráfico 9), pode-se observar que a maioria dos servidores possui algum tipo de pós-graduação (especializaçáo, mestrado e doutorado). A maior parte destes $(33,50 \%)$ tem alguma especialização ou pós-graduação lato sensu. Considerando-se os 30,20\% que obtiveram graduação, 93,80\% dos respondentes possuem pelo menos nível superior. ${ }^{17}$

17. Os elevados índices de resposta obtidos para os níveis de escolaridade mais altos - principalmente respondentes com pós-graduação - e os baixos índices para ensino fundamental e médio contrastam em alguma medida com os dados apresentados para a mesma variável na caracterização do universo. Essa forte presença de respondentes com níveis de escolaridade mais altos é reiterada pela variável carreira atual, com a grande maioria dos cargos registrados sendo de nível superior. É possível especular que parte dos servidores de cargos de nível fundamental e médio, usualmente cargos da áreameio, não tenha visto relação entre o tema do survey e seu trabalho, optando assim por não participar. Alguns comentários de avaliação do survey reforçavam essa possibilidade. 
GRÁFICO 9

Nível de escolaridade do servidor

(Em \%)

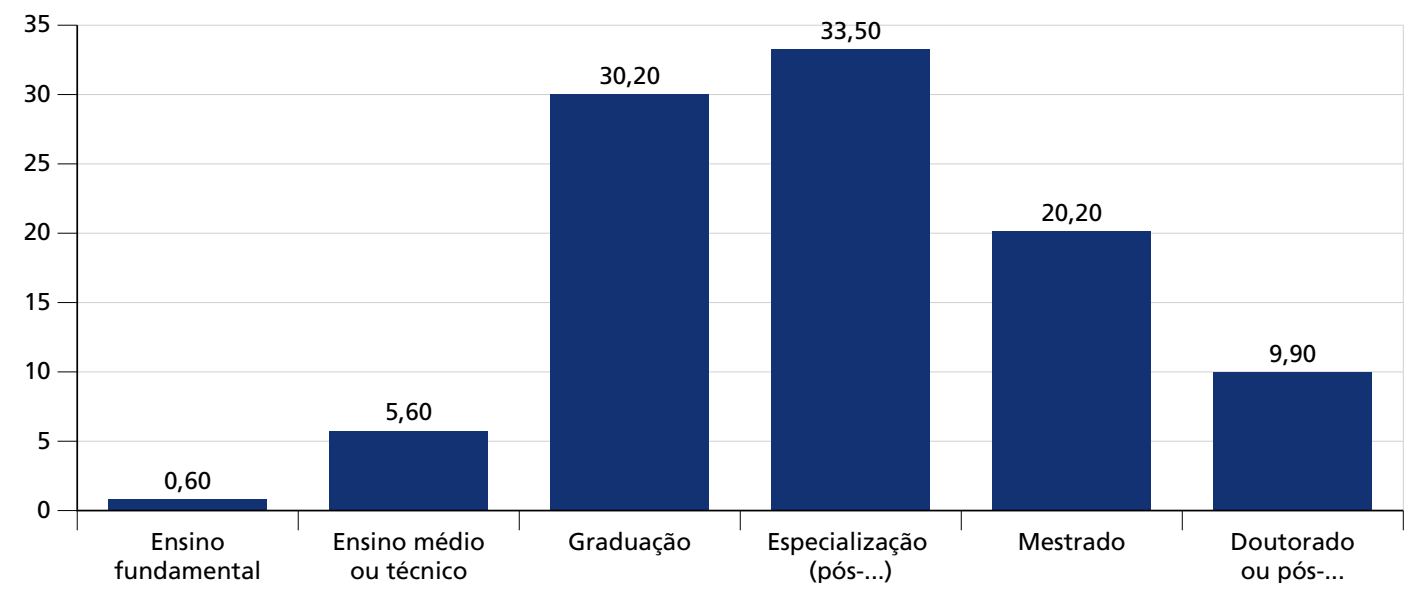

Fonte: Ipea.

Elaboração dos autores.

No que se refere à área de formação (tabela 5), verifica-se que a maior parte dos participantes possui formação na área de ciências sociais aplicadas (45,7\%). Em seguida, há aqueles que possuem formação em ciências humanas (17\%).

TABELA 5

Área de formação do título mais alto do servidor

(Em \%)

\begin{tabular}{lc}
\hline Área & Válido \\
\hline Ciências sociais aplicadas & 45,70 \\
Ciências humanas & 17,00 \\
Engenharias & 9,70 \\
Ciências exatas e da terra & 7,40 \\
Ciências da saúde & 5,40 \\
Ciências agrárias & 5,20 \\
Outros & 4,60 \\
Ciências biológicas & 2,90 \\
Linguística, artes e letras & 2,20 \\
\hline
\end{tabular}

Fonte: Ipea.

Elaboração dos autores.

Para a variável deficiência autodeclarada, 94,6\% dos participantes afirmaram não possuir nenhum tipo de deficiência. Enquanto somente 3,30\% declararam possuir alguma deficiência. 


\subsection{Trabalho e funções de políticas públicas}

Nesta segunda subseção, serão apresentados os dados obtidos a respeito do trabalho dos burocratas na política pública. Assim, inicialmente, analisar-se-ão a distribuição dos respondentes nas diferentes áreas de políticas públicas e seu tempo de experiência nessas políticas. Em seguida, serão apresentados os resultados sobre as funçôes desempenhadas por tais burocratas e os atores/organizaçóes com quem interagem para tal.

Vale esclarecer que foi dada a seguinte definição de políticas públicas aos servidores para o preenchimento de todas as questôes do survey: "Nesta pesquisa, entendemos políticas públicas como o conjunto de decisóes, programas e açóes governamentais conduzidos pela administração pública para oferta de serviços e soluçóes de problemas de interesse público".

No que se refere à distribuição dos respondentes segundo as políticas públicas, foi perguntado aos servidores Em qual programa do Plano Plurianual 2016-2019 a politica pública na qual você trabalha se insere?. Na primeira parte da pergunta, os respondentes poderiam selecionar uma das quatro áreas previstas no Plano Plurianual (PPA) 20162019; na segunda parte, poderiam apontar um programa específico naquela área.

TABELA 6

Programa do PPA 2016-2019 no qual a política pública se insere

\begin{tabular}{lcc}
\hline & Número & $\begin{array}{c}\text { Simples } \\
(\%)\end{array}$ \\
\hline Sem resposta & 753 & 34,60 \\
Social e segurança pública & 521 & 23,90 \\
Desenvolvimento produtivo e ambiental & 391 & 17,90 \\
Temas especiais & 330 & 15,10 \\
Infraestrutura & 185 & 8,60 \\
Total & $\mathbf{2 . 1 8 0}$ & $\mathbf{1 0 0}$ \\
\hline$\quad$ Fonte: Ipea. & &
\end{tabular}

$\mathrm{Na}$ tabela 6 , verifica-se que a maior parte dos respondentes deixou essa questão sem resposta $(34,6 \%)$. É possível que muitos respondentes não tivessem familiaridade com as nomenclaturas de áreas do PPA 2016-2019 e, por isso, tenham optado por não responder. ${ }^{18} \mathrm{Ou}$, ainda, que estejam alocados em áreas organizacionais não restritas a 
uma política específica, como assessoramento ou gestão interna, o que pode ter dificultado essa categorização.

Com relação aos que responderam, o maior grupo atuava nas áreas social e de segurança pública com $23,90 \%$, seguidos daqueles que assinalaram atuar na área de desenvolvimento produtivo/ambiental e temas especiais, com 17,9\% e 15,1\%, respectivamente. A área de infraestrutura foi a que obteve menor número de respostas com $8,6 \%$.

A tabela 7 apresenta o percentual de respondentes para os programas específicos das quatro áreas do PPA 2016-2019. Para facilitar a leitura, os programas estão dispostos por área e ordenados do mais frequente ao menos frequente.

TABELA 7

Programa específico do PPA - por área

\begin{tabular}{|c|c|c|c|}
\hline Área do PPA & Programa específico do PPA & Número & $\begin{array}{c}\text { Válido } \\
(\%)\end{array}$ \\
\hline \multirow{19}{*}{$\begin{array}{l}\text { Social e } \\
\text { segurança } \\
\text { pública }\end{array}$} & Justiça, Cidadania e Segurança Pública & 92 & 7,2 \\
\hline & Educação de Qualidade para Todos & 56 & 4,4 \\
\hline & Cultura: Dimensão Essencial do Desenvolvimento & 49 & 3,8 \\
\hline & Fortalecimento do Sistema Único de Saúde (SUS) & 47 & 3,7 \\
\hline & Previdência Social & 45 & 3,5 \\
\hline & Inclusão Social por meio do Bolsa Família, do Cadastro Único e da Articulação de Políticas Sociais & 40 & 3,1 \\
\hline & Promoção do Trabalho Decente e Economia Solidária & 34 & 2,7 \\
\hline & Consolidação do Sistema Único de Assistência Social (Suas) & 29 & 2,3 \\
\hline & Esporte, Cidadania e Desenvolvimento & 25 & 2 \\
\hline & Segurança Alimentar e Nutricional & 16 & 1,2 \\
\hline & Promoção e Defesa dos Direitos Humanos & 14 & 1,1 \\
\hline & Promoção, Proteção e Defesa dos Direitos Humanos de Crianças e Adolescentes & 8 & 0,6 \\
\hline & Fortalecimento e Dinamização da Agricultura Familiar & 5 & 0,4 \\
\hline & Promoção da Igualdade Racial e Superação do Racismo & 3 & 0,2 \\
\hline & Reforma Agrária e Governança Fundiária & 3 & 0,2 \\
\hline & Políticas para as Mulheres: Promoção da Igualdade e Enfrentamento à Violência & 2 & 0,2 \\
\hline & Promoção dos Direitos da Juventude & 1 & 0,1 \\
\hline & Proteção e Promoção dos Direitos dos Povos Indígenas & 1 & 0,1 \\
\hline & Redução do Impacto Social do Álcool e Outras Drogas: Prevenção, Cuidado e Reinserção Social & 1 & 0,1 \\
\hline
\end{tabular}


Texto para

Discussão

26190 Que Informa as Políticas Públicas: survey sobre o uso e o não uso de evidências pela burocracia federal brasileira

(Continuação)

\begin{tabular}{|c|c|c|c|}
\hline Área do PPA & Programa específico do PPA & Número & $\begin{array}{c}\text { Válido } \\
(\%)\end{array}$ \\
\hline \multirow{13}{*}{$\begin{array}{l}\text { Desenvolvimento } \\
\text { produtivo e } \\
\text { ambiental }\end{array}$} & Ciência, Tecnologia e Inovação & 96 & 7,5 \\
\hline & Conservação e Uso Sustentável da Biodiversidade & 61 & 4,8 \\
\hline & Defesa Agropecuária & 44 & 3,4 \\
\hline & Desenvolvimento da Indústria, Comércio e Serviços & 33 & 2,6 \\
\hline & Qualidade Ambiental & 26 & 2 \\
\hline & Comércio Exterior & 25 & 2 \\
\hline & Agropecuária Sustentável & 23 & 1,8 \\
\hline & Recursos Hídricos & 19 & 1,5 \\
\hline & Mudança do Clima & 18 & 1,4 \\
\hline & Desenvolvimento e Promoção do Turismo & 14 & 1,1 \\
\hline & Pesquisa e Inovações para a Agropecuária & 7 & 0,5 \\
\hline & Pesca e Aquicultura & 6 & 0,5 \\
\hline & Simplificação da Vida da Empresa e do Cidadão: Bem Mais Simples Brasil & 1 & 0,1 \\
\hline \multirow{8}{*}{ Temas especiais } & Democracia e Aperfeiçoamento da Gestão Pública & 97 & 7,6 \\
\hline & $\begin{array}{l}\text { Gestão da Política Econômica, Garantia da Estabilidade do Sistema Financeiro Nacional e Melhoria } \\
\text { do Ambiente de Negócios }\end{array}$ & 58 & 4,5 \\
\hline & Política Externa & 43 & 3,4 \\
\hline & Defesa Nacional & 31 & 2,4 \\
\hline & Desenvolvimento Regional e Territorial & 26 & 2 \\
\hline & Política Espacial & 23 & 1,8 \\
\hline & Oceanos, Zona Costeira e Antártica & 2 & 0,2 \\
\hline & Política Nuclear & 1 & 0,1 \\
\hline \multirow{13}{*}{ Infraestrutura } & Transporte Terrestre & 28 & 2,2 \\
\hline & Energia Elétrica & 27 & 2,1 \\
\hline & Transporte Aquaviário & 16 & 1,2 \\
\hline & Saneamento Básico & 13 & 1 \\
\hline & Mobilidade Urbana e Trânsito & 13 & 1 \\
\hline & Planejamento Urbano & 12 & 0,9 \\
\hline & Moradia Digna & 10 & 0,8 \\
\hline & Comunicações para o Desenvolvimento, a Inclusão e a Democracia & 9 & 0,7 \\
\hline & Gestão de Riscos e de Desastres & 9 & 0,7 \\
\hline & Petróleo e Gás & 8 & 0,6 \\
\hline & Geologia, Mineração e Transformação Mineral & 6 & 0,5 \\
\hline & Aviação Civil & 3 & 0,2 \\
\hline & Combustíveis & 2 & 0,2 \\
\hline Total & & 1.281 & 100 \\
\hline
\end{tabular}

Fonte: Ipea.

Elaboração dos autores. 
De modo semelhante aos dados obtidos no survey de 2017 (Enap, 2018), os dados da pesquisa atual demonstram que os participantes estáo envolvidos em praticamente todos os programas do PPA 2016-2019, ainda que em alguns programas o número de respondentes seja baixo. Entretanto, os dados corroboram mais uma vez a constatação da heterogeneidade de contextos de atuação da burocracia federal.

Em relação ao tempo de atuação na politica pública, verifica-se no gráfico 10 que grande parte dos respondentes possui longa experiência na área, com 40\% deles atuando há mais de dez anos na mesma política e $28 \%$ entre cinco e dez anos. Os servidores com um a cinco anos de atuação correspondem a $22 \%$, enquanto os recém-ingressos, entre seis meses e um ano e menos de seis meses, concernem a 7\% e 4\%. Esse padrão acompanha a tendência de redução de concursos públicos nos últimos anos.

\section{GRÁFICO 10}

Há quanto tempo trabalha nesta política pública

(Em \%)

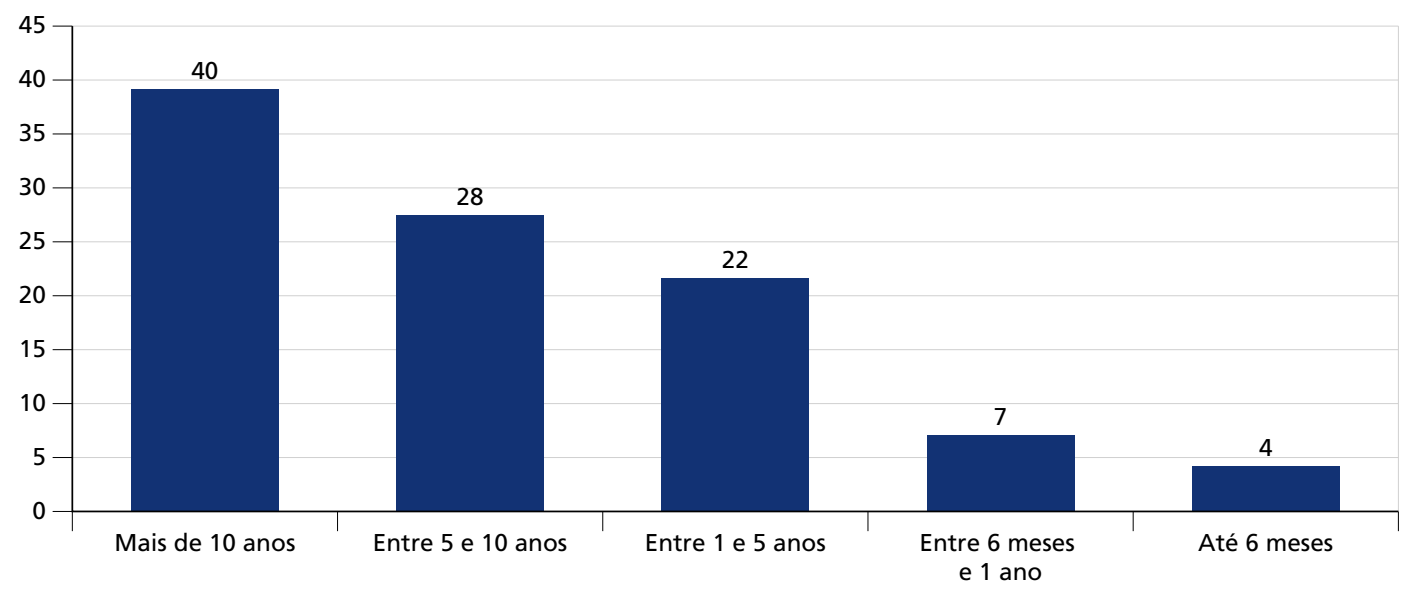

Fonte: Ipea.

Elaboração dos autores.

Para mapear o trabalho e funçôes desempenhadas pelos servidores no âmbito da política pública, foi feita a seguinte pergunta aos respondentes: Nos últimos 12 meses, com que frequência você executou as atividades abaixo relacionadas à politica pública na qual você trabalha?.

Fica demonstrado no gráfico 11 que as três atividades com os maiores índices de frequência entre os respondentes possuem fortes características de assessoramento e análise. A primeira, elaborar relatórios, pareceres, notas técnicas e outras informaçôes para 
subsidiar a tomada de decisóes, destaca-se com $63,6 \%$ dos participantes tendo afirmado realizá-la sempre ou frequentemente. Em segundo e terceiro lugar, as atividades realizar assessoramento de dirigentes e coletar e analisar dados relacionados à política pública aparecem respectivamente com $48,5 \%$ e $46 \%$ de respostas sempre ou frequentemente.

Como será reiterado pela análise fatorial da variável (tabela 7), esses resultados sugerem a existência de um conjunto de funçóes ligado fundamentalmente ao assessoramento de quadros superiores e à análise de documentos, informaçóes e dados com esse propósito. A presença desse conjunto entre os de maior frequência sugere que grande parte dos burocratas do Executivo federal, que responderam à pesquisa, está focada principalmente nessas atividades.

GRÁFICO 11

Funções desempenhadas por servidores no âmbito da política pública

(Em \%)

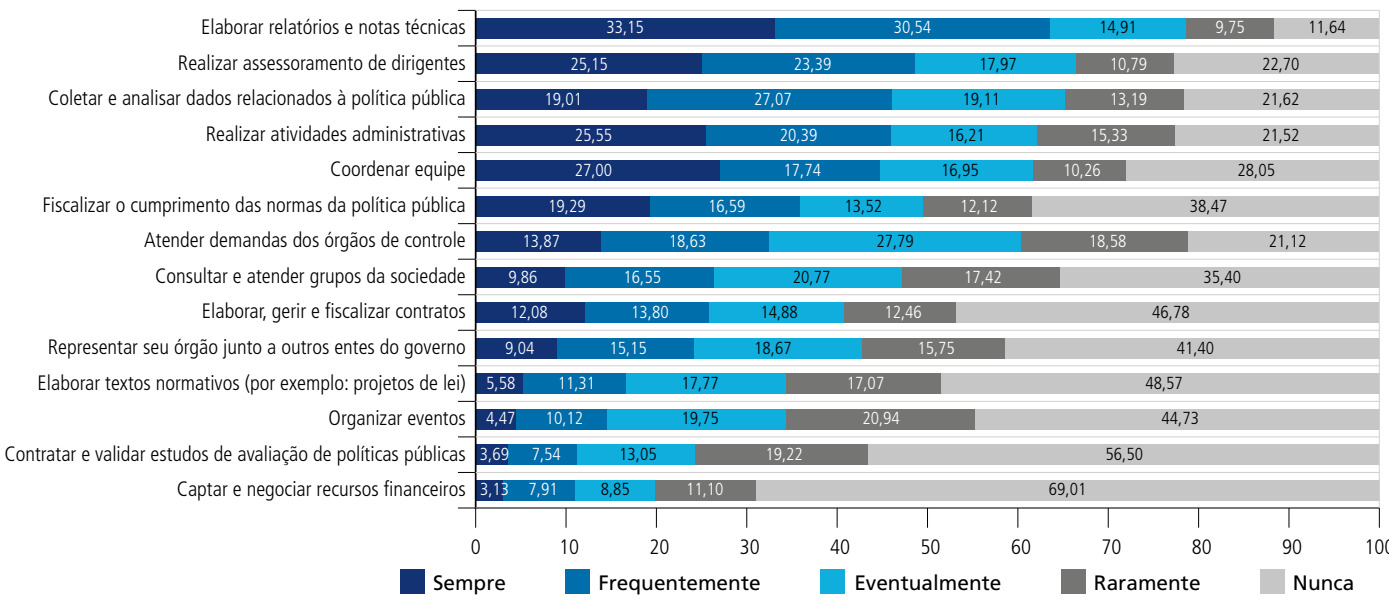

Fonte: Ipea.

Elaboração dos autores.

$\mathrm{Na}$ sequência, o índice de respondentes que afirmaram realizar atividades administrativas corrobora - com os dados encontrados na variável carreira e na análise fatorial que será apresentada a seguir - a existência de um quadro relevante de servidores que está voltado para as funçóes da área-meio. Essas atividades ocuparam o quarto lugar da lista, com 49,5\% dos participantes tendo declarado desempenhá-las sempre ou frequentemente.

Por sua vez, o conjunto de funçóes de controle também aparece bem delineado no gráfico, embora com percentual mais baixo. Os itens Fiscalizar o cumprimento das normas da política pública, Atender demandas dos órgãos de controle e Elaborar, gerir e 
fiscalizar contratos obtiveram respectivamente $35,88 \%, 32,50 \%$ e $25,89 \%$ de respostas sempre ou frequentemente.

No que tange às atividades/funçôes menos frequentes, Captar e negociar recursos financeiros para viabilizar açôes, projetos e programas da política pública e Contratar e validar estudos de avaliação de processos, resultados e impactos da política pública aparecem no fim da lista, com apenas $11,2 \%$ e $11 \%$ dos respondentes tendo afirmado executá-las sempre ou frequentemente.

Embora se tenha modificado alguns itens da questão para qualificação das respostas para o objeto desta pesquisa, pode-se dizer que os percentuais encontrados em 2019 para a variável funçôes desempenhadas no âmbito da política pública foram muito próximos aos encontrados no survey de 2017 (Enap, 2018), o que sugere a permanência de um mesmo ranking de atividades principais realizadas pelos servidores.

$\mathrm{Na}$ pesquisa de 2017, além da análise de frequências, também foi realizada a análise fatorial dos dados, com o intuito de investigar correlaçôes possíveis entre as funçôes desempenhadas e a existência de perfis comuns de atividades. ${ }^{19} \mathrm{Na}$ ocasião, foram encontrados quatro perfis específicos. O primeiro (analíticolaccountability) reunia tanto atividades analíticas como operacionalização de bases de dados e elaboração de pareceres, além de funções de controle, como atender a demandas desses órgãos e fiscalizar o cumprimento de normas. O segundo (relacional) envolvia tarefas de representação, negociação e coordenação com parceiros internos e externos da política pública. O terceiro perfil (gerenciamento de recursos) agrupava tarefas técnicas de mobilização de recursos para lidar com contratos, convênios e prospecção de recursos. Finalmente, o quarto perfil (administrativo) envolvia processos e tarefas operacionais do dia a dia, necessários ao funcionamento das organizaçôes (Enap, 2018).

Essa técnica de análise fatorial foi aplicada aos dados levantados nesse survey, e, assim como nas frequências, os resultados encontrados revelam tendência de permanência com relação ao quadro de 2017. Contudo, algumas variaçóes pontuais relevantes foram notadas e merecem comentário.

19. As técnicas exploratórias de análise fatorial são muito úteis quando há a intenção de trabalhar com variáveis que apresentem, entre si, coeficientes de correlação elevados e se deseja estabelecer novas variáveis que captem o comportamento conjunto das variáveis originais. Cada uma dessas novas variáveis é chamada de fator, que pode ser entendido como 0 agrupamento de variáveis a partir de critérios estabelecidos (Fàvero e Belfiore, 2015). 
A tabela 8 apresenta os resultados dessa análise para o survey de 2019. Esta explica cumulativamente $55,5 \%$ dos dados e também revela a existência de quatro perfis comuns de atividades - como em 2017. ${ }^{20}$

TABELA 8

Análise fatorial das funções desempenhadas na política pública (2019)

\begin{tabular}{|c|c|c|c|c|}
\hline Função/atividade & Analítico/controle & Relacional & $\begin{array}{c}\text { Gerenciamento de } \\
\text { contratos/fiscalização }\end{array}$ & Administrativo \\
\hline Elaborar relatórios e notas técnicas & 0.733 & - & - & - \\
\hline Coletar e analisar dados relacionados à política pública & 0.679 & 0.360 & - & - \\
\hline Elaborar textos normativos - por exemplo, projetos de lei & 0.535 & 0.370 & - & - \\
\hline Atender a demandas dos órgãos de controle & 0.435 & - & 0.378 & 0.407 \\
\hline Realizar assessoramento de dirigentes & 0.536 & 0.363 & - & 0.426 \\
\hline Contratar e validar estudos de avaliação de políticas públicas & 0.397 & 0.537 & 0.330 & - \\
\hline Captar e negociar recursos financeiros & - & 0.726 & 0.331 & - \\
\hline Representar seu órgão em associação a outros entes do governo & 0.458 & 0.600 & - & 0.323 \\
\hline Consultar grupos da sociedade e atender a estes & 0.467 & 0.490 & - & - \\
\hline Organizar eventos & - & 0.653 & - & 0.441 \\
\hline Coordenar equipe & 0.307 & 0.339 & - & 0.354 \\
\hline Elaborar, gerir e fiscalizar contratos & - & 0.313 & 0.727 & - \\
\hline Fiscalizar o cumprimento das normas da política pública & 0.415 & - & 0.467 & - \\
\hline Realizar atividades administrativas & - & - & - & 0.528 \\
\hline \multicolumn{5}{|l|}{ KMO: 0,$897 ; \chi^{2}=10015,460 ; d f=91 ; p<0,001$} \\
\hline \multicolumn{5}{|l|}{ Variação total explicada - 55,5\% } \\
\hline ss loadings & 2.672 & 2.497 & 1.322 & 1.281 \\
\hline
\end{tabular}

Como pode ser observado na tabela 8, os dados de 2019 revelaram perfis de atividades consideravelmente parecidos com os da pesquisa de 2017 . O primeiro perfil reúne principalmente atividades de cunho analítico (redigir relatórios e notas, coletar e analisar dados, bem como elaborar textos normativos), combinadas com funçóes de assessoramento e controle. O segundo perfil é focado nas atividades de caráter relacional (representar o órgão, atender a grupos da sociedade, organizar eventos e coordenar equipe), ${ }^{21}$ em associação à contratação de estudos e à captação de recursos. $\mathrm{O}$ terceiro

20. Os detalhes técnicos da análise fatorial estão disponíveis no apêndice deste texto para discussão. Este demonstra o passo a passo da análise e como se chegou aos quatro perfis.

21. A função coordenar equipe foi alocada no perfil relacional por uma decisão teórica. Por mais que esta tenha pontuado em três fatores diferentes e com carga fatorial ligeiramente mais elevada no fator administrativo, acredita-se que no dia a dia da burocracia esta tenha relação mais direta com as funções reunidas no perfil relacional. 
tipo, diferente de 2017, envolve o gerenciamento de contratos e a fiscalização das normas da política pública. E, finalmente, o quarto perfil é exclusivamente dedicado à realização de atividades administrativas.

Por um lado, as semelhanças com o quadro encontrado em 2017 são grandes. Temos novamente três perfis bem-definidos reunindo respectivamente atividades analíticas-controle, relacionais e administrativas. Por outro lado, existem diferenças pontuais importantes. A função de fiscalização, que em 2017 aparecia no perfil analítico, agora se encontra em outro perfil com o gerenciamento de contratos. Ainda assim, a relação traçada em 2017 entre análise e controle/fiscalização parece sustentar-se, dado que a função de fiscalização apresentou carga fatorial próxima também no perfil analítico. Por sua vez, a função de captação de recursos deixou de ser um perfil bem delineado com contratos, aparecendo em 2019 em associação às atividades de cunho relacional.

Além do mapeamento de funções no âmbito da política, também foram feitas perguntas a respeito da prática de leitura de publicaçôes em língua estrangeira, bem como de estudos e pesquisas científicas.

A primeira pergunta foi apresentada aos servidores da seguinte forma: Nos últimos 12 meses, como parte das suas atividades profissionais, você leu documentos e publicaçóes em lingua estrangeira?. Como se pode ver no gráfico 12, 54,9\% dos respondentes afirmaram que sim, enquanto $45,1 \%$ responderam que não.

\section{GRÁFICO 12}

Leitura de documentos e publicações em língua estrangeira por servidores (Em \%)

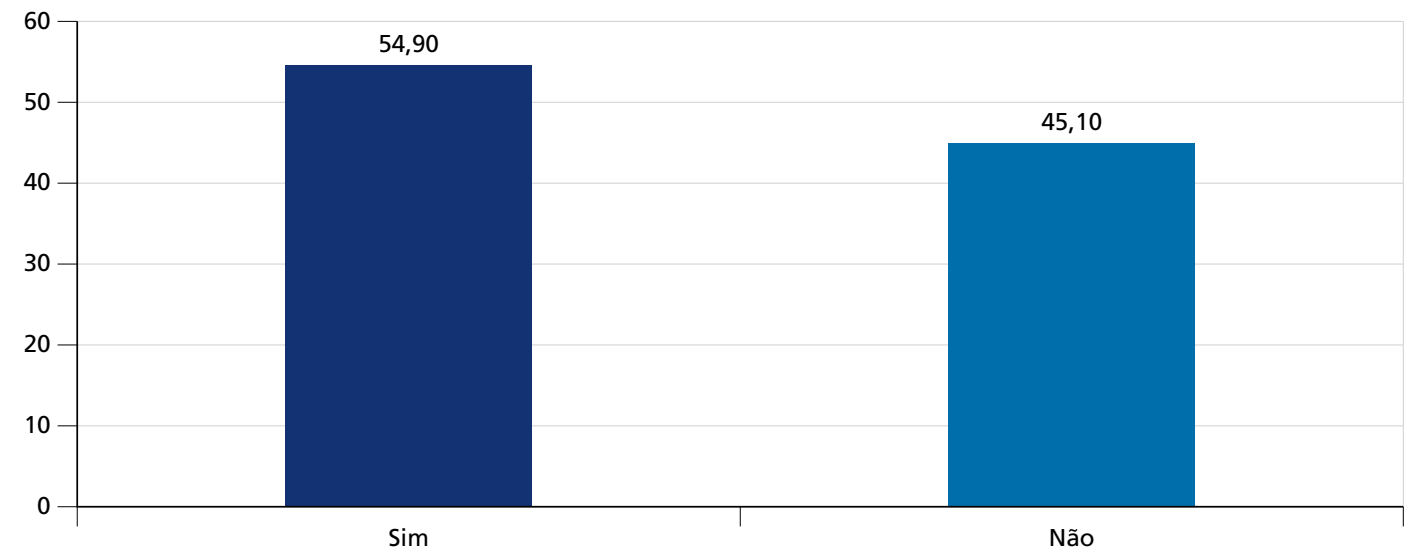

Fonte: Ipea.

Elaboração dos autores. 
Em seguida, foi perguntado qual ou quais eram os idiomas das publicações - os respondentes podiam selecionar mais de uma opção. As leituras em inglês destacaram-se, pois $51 \%$ de todos os respondentes do survey afirmaram ter lido uma ou mais publicaçôes nesse idioma nos últimos doze meses. Em seguida, aparecem as publicações em espanhol, lidas por $29 \%$ dos 2.180 respondentes. Por fim, aquelas em francês ou em outros idiomas, com respectivamente $7 \%$ e $2 \%$. Os dados estáo dispostos na tabela 9 .

TABELA 9

Idioma da publicação lida

(Em \%)

\begin{tabular}{lc}
\hline Idioma & Simples $^{1}$ \\
\hline Inglês & 51 \\
Espanhol & 29 \\
Francês & 7 \\
Outros & 2 \\
\hline
\end{tabular}

Fonte: Ipea.

Elaboração dos autores.

Nota: ${ }^{1} 0$ respondente poderia marcar mais de uma opção.

Ademais, os respondentes foram questionados sobre a prática de leitura de pesquisas e estudos científicos no âmbito do seu trabalho. Assim, após perguntar sobre a média de horas trabalhadas em uma semana típica, foi solicitado que o respondente indicasse o número de horas dedicadas tanto a reuniōes quanto à leitura de pesquisas científicas como medida de comparação.

A média é de quarenta horas trabalhadas por semana - considerados apenas os 2.146 registros válidos para essa questão. Chama atenção o fato de que a média de horas direcionadas para reunióes (seis horas) é menor do que a média de horas investidas na leitura de estudos e pesquisas (sete horas). Como será discutido, os resultados obtidos na subseção dedicada ao uso de evidências não corroboram esse dado.

BOX 2

Tempo de trabalho gasto com reuniões versus leitura de pesquisas

0 tempo médio gasto com reuniões em uma semana típica de trabalho é de seis horas.

Por sua vez, o tempo médio gasto com a leitura de pesquisas científicas é de sete horas.

Elaboração dos autores.

Finalmente, a última variável analisada na seção a respeito do trabalho dos respondentes com políticas públicas dizia respeito aos atores e organizaçôes com os quais o 
burocrata interage, o que na pesquisa de 2017 foi definido como "recursos interacionais" (Enap, 2018).

Como pode ser observado no gráfico 13, os dados obtidos neste survey demonstram forte tendência ao "ensimesmamento" por parte do Executivo federal, de modo que os maiores índices de interação ocorrem com pares e os menores índices, com outros poderes e a sociedade civil em geral. Essa tendência já podia ser observada nos dados obtidos em 2017 (Enap, 2018).

GRÁFICO 13

Atores/organizações com os quais o servidor interage

(Em \%)

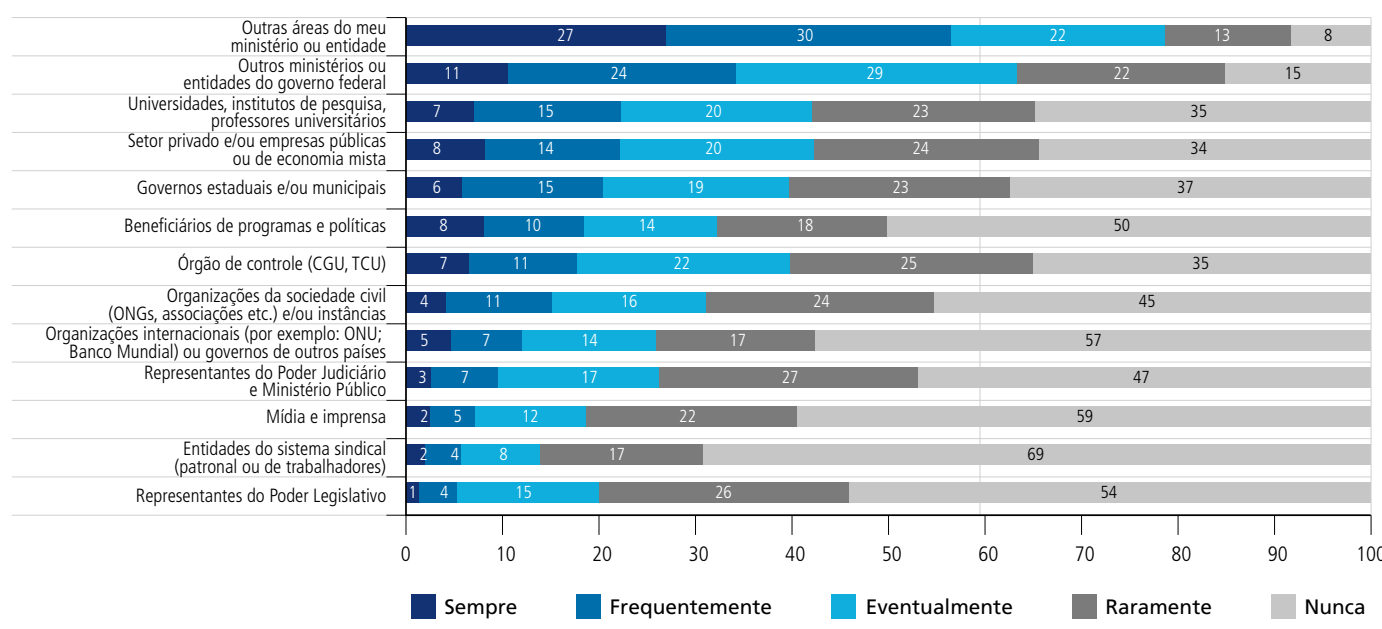

Fonte: Ipea.

Elaboração dos autores.

Os dados do gráfico 13 revelam, em primeiro lugar, forte tendência de interação centrada na própria administração federal: os burocratas interagem principalmente em seus próprios ministérios, bem como com os demais órgãos do governo federal. A saber, $57 \%$ dos respondentes declaram interagir com outras áreas do próprio órgão sempre ou frequentemente. No caso de Outros ministérios ou entidades do governo federal, o índice cai para $34 \%$.

Quando confrontados com os índices dos demais atores/organizaçôes, fica patente que existe forte assimetria: de forma geral, os burocratas federais interagem muito entre eles mesmos, mas bem menos com as burocracias locais e os demais atores da sociedade brasileira. Cabe destacar, no entanto, que esse recorte pode variar conforme a área de política pública, por exemplo. Algumas políticas sociais são estruturadas no formato 
de sistemas de políticas públicas, como saúde e assistência social, com maior interação federativa e com a sociedade civil.

Nesse sentido, os índices de interação com Universidades, institutos de pesquisa, professores e pesquisadores, Setor privado elou empresas públicas ou de economia mista e Governos estaduais elou municipais foram bem mais baixos, com respectivamente $22 \%, 22 \%$ e $21 \%$ de respostas sempre ou frequentemente. O cenário é pior no caso dos Beneficiários de programas e políticas e Organizaçoes da sociedade civil elou instâncias participativas, com os respectivos percentuais de $18 \%$ e $15 \%$ de respostas sempre ou frequentemente. Também chama atenção que os baixos índices aparecem na interação com Representantes do Poder Judiciário e Ministério Público e Representantes do Poder Legislativo, com respectivos 10\% e 5\% de respostas sempre ou frequentemente.

\subsection{Uso de informações e evidências científicas}

Nesta subseção, serão apresentados os resultados inéditos e que compóem o cerne deste survey. Trata-se de dados levantados a respeito de práticas e padróes de uso de informaçôes e evidências científicas por parte dos servidores públicos federais no seu trabalho com políticas públicas.

Assim, dimensões como os tipos de informação utilizados, as principais fontes de acesso a pesquisas e estudos científicos, os fatores determinantes para utilização desses documentos no trabalho com políticas públicas e os aspectos individuais e organizacionais que afetam a utilização ou não utilização de evidências científicas serão discutidas a seguir. Como conclusão da seção, também serão apresentados dados sobre a existência de estrutura institucional especializada na utilização de evidências científicas.

Espera-se que, ao fim, seja possível vislumbrar o quadro atual das dinâmicas de utilização de informaçôes e, principalmente, evidências científicas no âmbito do trabalho dos servidores em política pública.

$\mathrm{Na}$ primeira pergunta sobre o tema, os servidores foram solicitados a indicar a frequência com que utilizavam determinados tipos de informação no trabalho com 
política pública. ${ }^{22} \mathrm{~A}$ lista de opçóes apresentada foi pensada de forma ampla, com base na definição genérica da palavra informação, de modo que não se restringiu apenas aos tipos de caráter científico.

Como demonstrado no gráfico 14 , os tipos de informação mais frequentemente utilizados pelos servidores respondentes são de caráter endógeno. Ou seja, usualmente são informações, opinióes e conhecimentos produzidos pela própria burocracia que endossam seu trabalho com políticas públicas. Essa constatação corresponde ao esperado da operação de sistemas especializados, como a burocracia pública.

Dessa forma, no topo da lista, leis e normas destacam-se como o tipo de informação mais utilizado pelos servidores, com $82,11 \%$ dos respondentes declarando utilizá-las sempre ou frequentemente. $\mathrm{O}$ dado revela forte tendência da burocracia a recorrer às bases normativas para ancorar seu trabalho na política pública.

Em seguida, a consulta a colegas de trabalho e a experiência pessoal aparecem como formas de informação/conhecimento extremamente presentes, respectivamente com $75,87 \%$ e $64,59 \%$ dos respondentes tendo declarado aplicá-las sempre ou frequentemente. Trata-se de dado relevante, pois demonstra a importância das relaçóes interpessoais e das trajetórias individuais para a compreensão das práticas de utilização de evidências pelos burocratas.

Contudo, a presença subsequente das notas técnicas produzidas por órgãos federais e dos sistemas informacionais e bases de dados governamentais, com respectivamente 62,66\% e 49,82\% dos servidores indicando que os empregam sempre ou frequentemente, permite afirmar que parte importante da burocracia federal tem incorporado informaçóes e conhecimentos de caráter factual-analítico nas rotinas de trabalho - ainda que o caráter endógeno permaneça.

Outro aspecto que merece ser sublinhado é a frequência de pareceres legais e decisóes judiciais e recomendaçôes de órgáos de controle, com 50,18\% e 49,45\% dos servidores tendo afirmado que os utilizam sempre ou frequentemente. Seguindo a mesma tendência

22. Não foi possível comparar a variável tipos de informação com os dados obtidos na pesquisa de 2017, porque os itens apresentados aos respondentes variaram tanto no conteúdo quanto na forma de apresentação. Ainda assim, tendências parecidas podem ser destacadas: i) o baixo índice de utilização de modalidades "científicas" como dados estatísticos; ii) o baixíssimo índice de utilização de produções da própria sociedade (beneficiários, conselhos, instâncias participativas etc.); e iii) a presença de destaque de documentos e recomendações elaborados por órgãos de controle. 
dos dados encontrados sobre as funções desempenhadas, a incidência desses dois itens mostra que parte considerável dos burocratas tem se embasado em produções e documentos ligados ao controle e à fiscalização, o que faz questionar se essas fontes trariam indiretamente referências de evidências científicas.

Como será mais bem discutido a seguir, nota-se que parte importante dos burocratas está inclinada à utilização de evidências científicas, mas essa prática está majoritariamente amparada pela produção de conhecimentos a partir de dados e sistemas informatizados do próprio Executivo federal.

GRÁFICO 14

Tipos de informação utilizada no trabalho com políticas públicas

(Em \%)

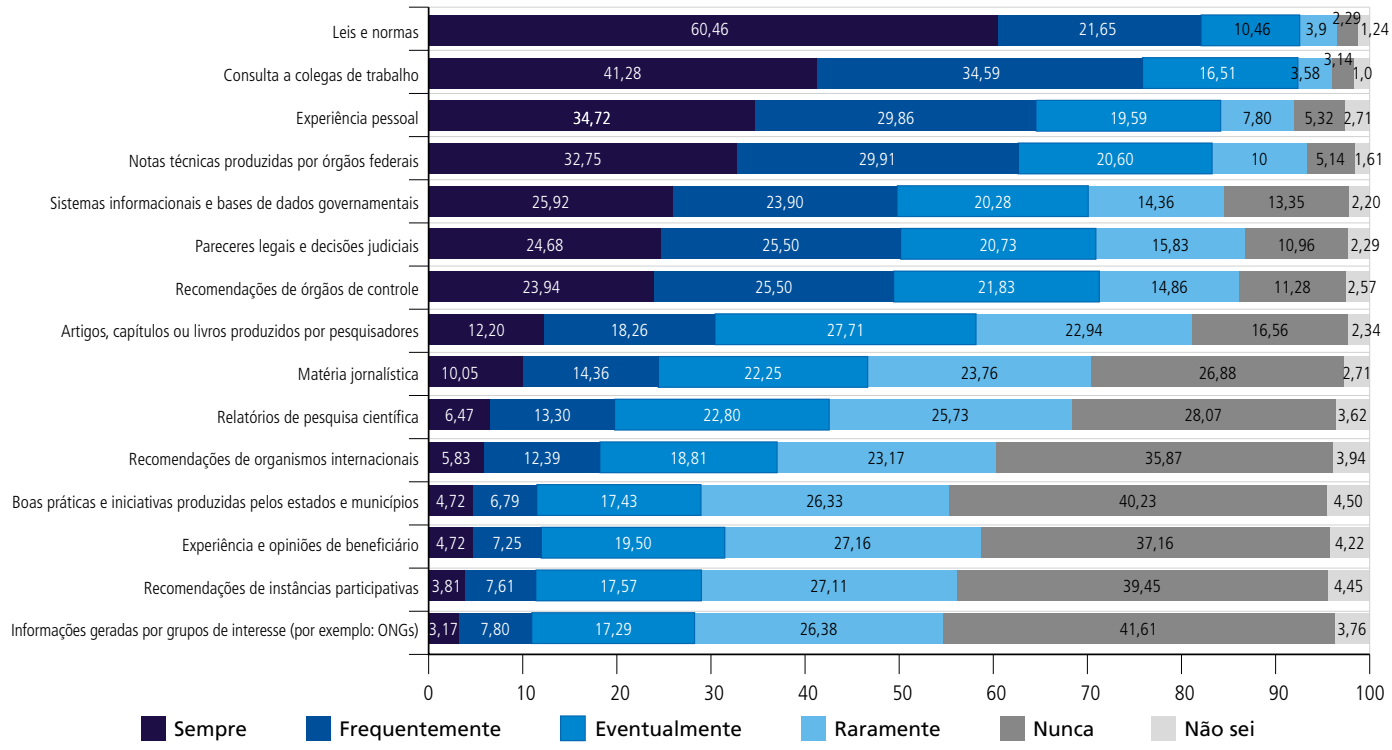

Fonte: Ipea.

Elaboração dos autores.

No que diz respeito aos itens que convencionalmente constituem o cerne do debate sobre o uso de evidências, a saber, os Artigos, capitulos ou livros produzidos por pesquisadores e os Relatórios de pesquisa cientifica - por exemplo, produtos de consultoria de pesquisa, textos de discussão do Ipea etc. -, os dados obtidos sugerem um quadro de menor relevância. No caso das publicações acadêmicas, 30,46\% dos respondentes afirmaram adotá-las sempre ou frequentemente. Os relatórios aparecem com menor frequência, com 19,77\% utilizando-os sempre ou frequentemente. Quando considerados apenas os 
servidores que responderam sempre, o índice dos dois itens cai bastante. Apenas 12,20\% afirmaram recorrer às publicaçôes acadêmicas sempre e 6,47\%, aos relatórios de pesquisa.

Assim como no caso dos percentuais de interação entre burocratas e acadêmicos, os números referidos anteriormente revelam incidência relativamente baixa da produção científica sobre o trabalho dos servidores com políticas públicas. O contraste dessa baixa incidência com a forte presença de documentos analíticos e estatísticas produzidos pelo próprio Estado aponta para o sentido da teoria das duas comunidades (Caplan 1979; Dunn 1980). Ou seja, a hipótese de que burocratas e acadêmicos formam duas comunidades separadas, que operam com regras e linguagens diferentes e que possuem poucas linhas de conexão/comunicação entre si. ${ }^{23}$

Não seria justo, no entanto, afirmar que os burocratas federais não utilizam evidências no seu trabalho. Notas técnicas, bases de dados governamentais, pareceres legais são modalidades de informação com um alto grau de sistematicidade, capacidade analítica e até mesmo verificação empírica - quando não estão direta ou indiretamente ancorados em produçóes acadêmicas. O que ocorre é que essa utilização é majoritariamente amparada pela estrutura de produção de conhecimento da própria burocracia federal e não das universidades. Mais uma vez, existe um "ensimesmamento" da burocracia e um respectivo distanciamento/falta de diálogo com o universo acadêmico-científico. Ademais, pode-se especular, seguindo as sugestóes de Newman et al. (2016), que as contribuiçóes do campo científico cheguem aos burocratas de forma indireta, diluídas em meio a toda essa produção interna de conhecimento. ${ }^{24}$

Finalmente, nas últimas colocaçóes do gráfico 14, encontramos os tipos de informação menos empregados pela burocracia federal, desvelando outro dado extremamente preocupante. Assim como na variável "Atores com quem interage", há baixíssima absorção de informaçôes geradas pela própria sociedade por parte do quadro de funcionários do Executivo federal. Informaçôes geradas por grupos de interesse - por exemplo, sindicatos, empresas, movimentos sociais, organizaçôes não governamentais (ONGs) etc. -, Experiência e opinióes de beneficiário da política pública ou comentários e sugestôes de

23. A teoria das duas comunidades foi formulada ainda na década de 1980 e, desde então, vem sendo amplamente utilizada nas pesquisas sobre PPBEs. Mais recentemente, esta foi criticada por trabalhos empíricos que mostraram que o diálogo entre burocracia e campo científico não ocorre de maneira direta, mas por meio de inúmeros intermediários que precisam ser mais bem estudados (Newman et al., 2016).

24. Em complemento, pode-se destacar que os tipos comuns de produção técnica da burocracia (notas técnicas, pareceres e outras formas de análise) não se conformam à indicação padronizada de referências bibliográficas de natureza científica. Assim, a produção interna muitas vezes não explicita fontes científicas, mesmo que tenha sido baseada nestas. 
ouvidoria e Recomendaçôes de instâncias participativas - como é o caso de conselhos de políticas públicas, conferências etc. - são os tipos de informação menos frequentes na rotina de trabalho dos servidores, com percentual em torno de $10 \%$ de respondentes que declaram utilizá-los sempre ou frequentemente.

A variável tipo de informação também foi submetida à técnica de análise fatorial, mais uma vez com o intuito de detectar correlaçôes e, logo, perfis comuns. A tabela 10 traz o resultado da análise, que explica cumulativamente $63,2 \%$ dos dados e revela quatro perfis comuns para a variável. ${ }^{25}$

TABELA 10

Análise fatorial dos tipos de informação utilizados no trabalho com políticas públicas

\begin{tabular}{|c|c|c|c|c|}
\hline Tipo de informação & Interno & Externo & Acadêmico & Pessoal \\
\hline Leis e normas & 0,793 & - & - & - \\
\hline Notas técnicas produzidas por órgãos federais & 0,835 & - & - & - \\
\hline Pareceres legais e decisões judiciais & 0,869 & - & - & - \\
\hline Recomendações de órgãos de controle & 0,794 & - & - & - \\
\hline Sistemas informacionais e bases de dados governamentais & 0,496 & - & - & - \\
\hline Boas práticas e iniciativas produzidas pelos estados e municípios & 0,333 & 0,556 & - & - \\
\hline Recomendações de instâncias participativas & - & 0,727 & 0,361 & - \\
\hline Experiência e opiniões de beneficiário & - & 0,741 & - & - \\
\hline Informações geradas por grupos de interesse - por exemplo, ONGs & - & 0,784 & - & - \\
\hline Recomendações de organismos internacionais & - & 0,592 & 0,413 & - \\
\hline Matéria jornalística & - & 0,419 & - & 0,302 \\
\hline Artigos, capítulos ou livros produzidos por pesquisadores & - & 0,303 & 0,8 & - \\
\hline Relatórios de pesquisa científica & - & 0,461 & 0,822 & - \\
\hline Experiência pessoal & - & - & - & 0,651 \\
\hline Consulta a colegas de trabalho & 0,32 & - & - & 0,731 \\
\hline \multicolumn{5}{|l|}{ KMO: 0,$869 ; \chi^{2}=14009,490 ; d f=105 ; p<0,001$} \\
\hline \multicolumn{5}{|l|}{ Variação total explicada $(63,2 \%)$} \\
\hline SS loadings & 3.331 & 2.988 & 1.816 & 1.339 \\
\hline
\end{tabular}

Fonte: Ipea.

Elaboração dos autores.

A análise fatorial dos tipos de informação sugeriu a existência de quatro perfis específicos. Na tabela 10 , pode-se observar que esses perfis se caracterizam principalmente pela origem específica do tipo de informação. Assim, o perfil interno reúne tipos

25. Os detalhes técnicos da análise fatorial estão disponíveis no apêndice deste TD. Este demonstra o passo a passo da análise e como se chegou aos perfis. 
de informação produzidos pela estrutura da própria burocracia federal (leis e normas, notas técnicas, pareceres legais etc). Por sua vez, o perfil externo envolve tipos de informação produzidos por outros atores governamentais e sociais, em movimento de fora pra dentro da burocracia federal (boas práticas de estados e municípios, recomendaçóes de organismos internacionais, informaçóes de grupos de interesse e beneficiários etc.). Por seu turno, o terceiro perfil (acadêmico) diz respeito aos tipos de informação produzidos pelo campo especializado de acadêmicos e pesquisadores (artigos, livros e relatórios de pesquisa). Finalmente, o quarto perfil (pessoal) reúne tipos de informação vinculados à experiência pessoal adquirida pelo próprio servidor e por seus colegas de trabalho ao longo da carreira.

Um ponto que merece destaque é o acerca dos dados apresentados no gráfico 14 e na tabela 10 quanto à maior incidência de uso e conformação de um tipo específico de informaçóes produzidas pelo próprio Estado. Considerando-se que o tipo de organização burocrática trata da organização de natureza de dominação racional-legal, como já observado por Weber (1963), uma possível explicação para a configuração desse retrato de "ensimesmamento" poderia ser a necessidade por parte da burocracia de uma etapa de chancela ou validação do processo de absorção do conhecimento oriundo de fontes externas. Isto é, seria necessária a transformação, a tradução do conhecimento externo em instrumento informacional válido e palatável para o uso da administração pública. Talvez os instrumentos elencados como internos como pareceres, notas técnicas e recomendaçóes sirvam, em parte, intencionalmente ou não intencionalmente a esse propósito. Ou seja, é possível que fontes como trabalhos científicos ou produzidas por diferentes stakeholders das políticas influenciem indiretamente a produção da política pública por meio desses instrumentos internos. Essa é uma hipótese que merece ser explorada em estudos futuros.

A próxima pergunta da subseção Uso de informaçôes e evidências científicas já deixa de lado o conceito genérico de informação, com o objetivo de analisar especificamente os tipos de pesquisas e estudos cientificos mais utilizados pelos servidores no âmbito do seu trabalho com políticas públicas. Desse modo, a questão indagava com que frequência o servidor recorria a quatro modalidades diferentes de pesquisa.

Como na questão anterior sobre tipos de informação, os dados obtidos mais uma vez revelam baixa presença de todas as modalidades de pesquisa científica na rotina dos servidores. Como pode ser observado na tabela 11 , todos os quatro itens obtiveram baixíssimo percentual de respondentes que marcaram a frequência sempre. A saber, $6,70 \%$ 
para estudos teóricos, 4,72\% para estudos quantitativos, 4,13\% para estudos qualitativos e 3,62\% para estudos com métodos mistos.

Até mesmo quando somados os respondentes que marcaram sempre e frequentemente, os percentuais ainda são baixos, com 21,61\% para estudos teóricos, 16,01\% para estudos quantitativos, $13,85 \%$ para estudos qualitativos e $13,99 \%$ para estudos com métodos mistos.

\section{TABELA 11}

Tipos de pesquisas e estudos científicos versus frequência de utilização (Em \%)

\begin{tabular}{lcccccc}
\hline Tipo de pesquisa & Sempre & Frequentemente & Eventualmente & Raramente & Nunca & Não sei \\
\hline Estudos de revisão de literatura ou teóricos & 6,70 & 14,91 & 19,86 & 21,42 & 31,56 & 5,55 \\
Estudos baseados em métodos quantitativos & 4,72 & 11,28 & 20,46 & 22,75 & 35,50 & 5,28 \\
Estudos baseados em métodos qualitativos & 4,13 & 9,72 & 22,06 & 23,03 & 35,83 & 5,23 \\
Estudos baseados em métodos mistos (quanti-quali) & 3,62 & 10,37 & 20,32 & 21,10 & 37,20 & 7,39 \\
\hline$\quad$ Fonte: Ipea. & & & & &
\end{tabular}

Uma das explicaçôes levantadas pela teoria das duas comunidades é que burocratas e acadêmicos utilizam linguagens e regras diferentes, vinculadas a campos de atuaçáo distintos. Dessa forma, pode-se especular o quáo distantes as linguagens e os protocolos dessas diferentes modalidades de pesquisa estão da realidade cotidiana dos burocratas. Como será discutido a seguir, ao analisar-se o gráfico 15 , os dados obtidos sobre os fatores determinantes para utilização de pesquisas também corroboram essa ideia.

A terceira questão da subseção procurava mapear os meios e formas de acesso dos servidores às evidências científicas no âmbito do seu trabalho. Desse modo, a seguinte pergunta foi apresentada: Como você toma conhecimento de resultados de pesquisas e estudos científicos relevantes para o seu trabalho?. O respondente podia marcar quantas opções quisesse.

Como pode ser observado na tabela 12, o principal meio de acesso aos resultados de pesquisas científicas por parte dos burocratas são as ferramentas de busca on-line, como o Google. Dos 2.180 respondentes, $76 \%$ sinalizaram essa opção. O alto índice parece justificado pelo caráter de intermediário que esses sites cumprem no acesso à informação atualmente. 
Em segundo lugar, a imprensa aparece como forma de acesso para 53,2\% dos participantes. Seguindo essa lógica, a importância da imprensa como disseminadora de informações de interesse social explicaria o índice elevado.

Em terceiro, eventos e congressos científicos aparecem com 51,8\%. Esse percentual mais uma vez indica a importância das relaçôes interpessoais e das redes de cooperação no acesso e na utilização de evidências. Contudo, é bem provável que grande parte dos respondentes tenha marcado essa opção por conta de eventos oficiais promovidos pelo próprio Estado - o que explicaria a discrepância desse dado no que concerne ao índice de interação com acadêmicos. A força das relações interpessoais também é indicada pelo percentual do item indicação de conhecidos, com 46,3\%.

Uma menção de destaque deve ser feita para a presença da busca em sites de instituiçôes de pesquisa, com 47,7\% das respostas, revelando a importância de portais de instituiçóes como o Ipea e o Instituto Brasileiro de Geografia e Estatística (IBGE), por exemplo.

Por sua vez, mais uma vez, as fontes convencionalmente tidas como científicas ou acadêmicas apresentaram percentual mais baixo do que os demais. Os itens portais de periódicos e citaçóes acadêmicas aparecem respectivamente com 34\% e 32,6\%. Nessa linha, a busca presencial ou em sites de bibliotecas aparece com somente $21,8 \%$. Ou seja, novamente, evidencia-se a baixa inclinação dos servidores no sentido das fontes convencionais de acesso ao conhecimento científico.

TABELA 12

Fontes de acesso a pesquisas e estudos científicos

(Em \%)

\begin{tabular}{lc}
\hline Fonte de acesso & Simples $^{1}$ \\
\hline Google ou outras ferramentas de busca & 76,0 \\
Imprensa & 53,2 \\
Eventos ou congressos científicos & 51,8 \\
Busca em sites de instituições de pesquisa & 47,7 \\
Indicação de conhecidos & 46,3 \\
Portal de periódicos ou banco de teses & 34,0 \\
Sites de organismos internacionais & 33,5 \\
Citações em estudos acadêmicos & 32,6 \\
Redes sociais - por exemplo, Facebook e WhatsApp & 28,8 \\
Busca presencial ou em sites de bibliotecas & 21,8 \\
Plataformas de áudio e vídeo (YouTube etc.) & 21,2 \\
\hline Fonte: Ipea. & \\
Nota: ' 0 respondente poderia marcar mais de uma opção. & \\
& \\
\hline &
\end{tabular}


A próxima questão do survey apresentava três tipos de uso de pesquisas e estudos científicos e perguntava ao participante, em uma escala de cinco pontos, o quanto ele concordava ou discordava com cada afirmativa no contexto do seu trabalho. Os três tipos de uso apresentados correspondem à tipologia criada por Beyer (1997), que diferencia os usos conceitual (esclarecimento), instrumental (açóes concretas) e simbólico (confirmação de escolhas prévias).

Os dados obtidos para amostra geral não apresentam nenhuma variação significativa, não oferecendo nenhuma conclusão. Em outra oportunidade, a desagregação das respostas obtidas a partir de outras variáveis poderá revelar alguma dinâmica que não foi possível detectar com os dados agregados.

TABELA 13

Contribuição do uso de pesquisas e estudos científicos no seu contexto de trabalho (Em \%)

\begin{tabular}{lcrrrrr}
\hline Tipo de pesquisa & $\begin{array}{c}\text { Concordo } \\
\text { totalmente }\end{array}$ & Concordo & Indiferente & Discordo $\begin{array}{c}\text { Discordo } \\
\text { totalmente }\end{array}$ & $\begin{array}{c}\text { Não } \\
\text { sei }\end{array}$ \\
\hline O uso de pesquisas e estudos científicos serve para esclarecer situações & 23,72 & 50 & 13,85 & 3,90 & 2,84 & 5,69 \\
O uso de pesquisas e estudos científicos leva a ações concretas & 21,70 & 45,55 & 17,66 & 5,55 & 2,89 & 6,65 \\
O uso de pesquisas e estudos científicos serve para confirmar escolhas já feitas & 21,61 & 46,10 & 16,79 & 5,09 & 3,35 & 7,06 \\
\hline$\quad$ Fonte: Ipea. & & & & & & \\
$\quad$ Elaboração dos autores. & & & & &
\end{tabular}

A questão subsequente procurou mapear os principais fatores que determinam o uso e o não uso de pesquisas e estudos científicos por parte dos burocratas. Para tal, a seguinte orientaçáo foi apresentada aos participantes: Indique qual o nivel de relevância dos fatores a seguir na sua decisão de utilizar informaçôes provenientes de pesquisas e estudos cientificos.

Os dados dispostos no gráfico 15 deixam claro que os principais fatores que determinam a utilização de uma pesquisa ou um estudo são a Credibilidade e prestígio da fonte e a Pertinência e aplicabilidade da informaçâo. Respectivamente, 63,62\% e 62,16\% dos respondentes afirmaram que esses dois fatores são muito relevantes ou decisivos na decisão de utilizar dada pesquisa.

Na sequência, os participantes sinalizaram que Existência de conclusóes e recomendaçôes de natureza operacional a a Facilidade de compreensão da pesquisa ou estudo científico também são importantes nesse contexto, com $47,11 \%$ e 45,96\% de burocratas tendo apontado que esses tópicos são muito relevantes ou decisivos. 
Os índices obtidos pelos fatores Pertinência e aplicabilidade da informação e Existência de conclusóes e recomendaçóes de natureza operacional reforçam a explicação de que regras e protocolos diferentes seriam responsáveis pela falta de diálogo entre burocratas e acadêmicos. Afinal, as respostas deixam claro que a compatibilidade prática entre as pesquisas e a realidade do servidor é requisito indispensável para sua utilização no trabalho com políticas públicas.

Por sua vez, a presença relevante do fator Facilidade de compreensão da pesquisa ou estudo científico demonstra que a (não) existência de linguagem em comum também é questão decisiva para a utilização de pesquisas por burocratas.

\section{GRÁFICO 15}

Fatores determinantes na utilização de pesquisas e estudos científicos (Em \%)

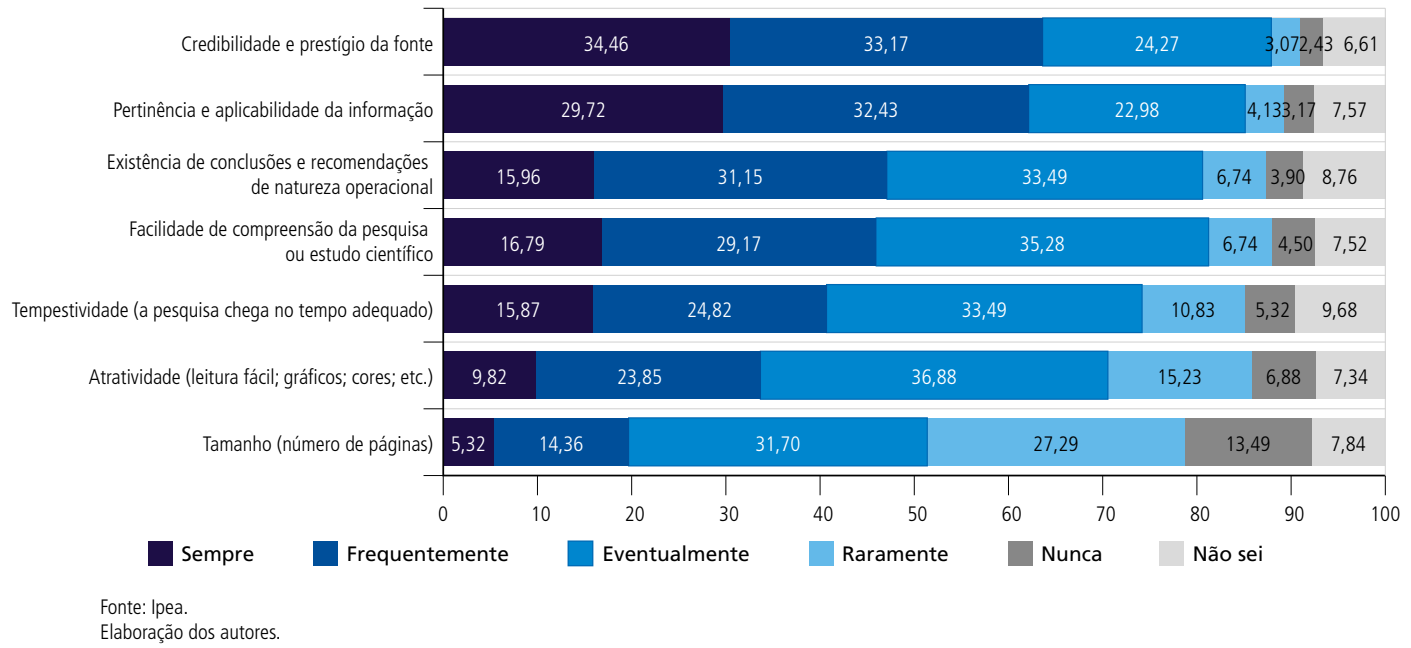

Em seguida, uma pergunta do questionário foi feita com o intuito de compreender como aspectos individuais e organizacionais impactam nas práticas de utilização de pesquisas e estudos científicos dos burocratas. Dessa forma, foi apresentada uma série de situações ligadas à utilização de evidências por parte do próprio indivíduo ou de sua organização, para que os participantes respondessem com que frequência estas ocorriam.

Mais uma vez, chama atenção como diferentes práticas e contextos de utilização de evidências tanto no plano individual quanto no plano organizacional apresentaram 
índices muito baixos. Em outros termos, essas práticas e contextos estão em grande medida ausentes na administração federal.

Os resultados para essa variável estão dispostos no gráfico 15 .

GRÁFICO 16

Aspectos individuais e organizacionais e sua relação com a utilização de pesquisas e estudos científicos

(Em \%)

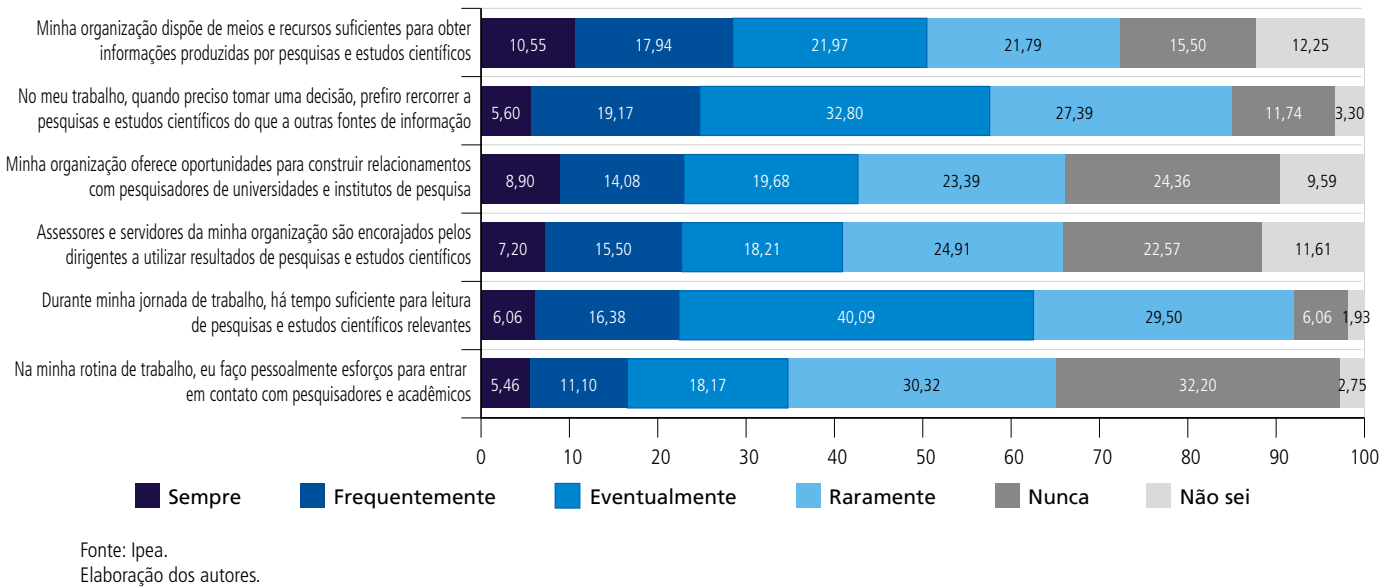

Nesse sentido, 65,28\% dos respondentes afirmaram que não sabiam ou nunca e raramente faziam esforços pessoais para entrar em contato com pesquisadores e acadêmicos. $\mathrm{O}$ dado endossa todos os demais que revelaram um enorme afastamento entre os membros dos campos burocrático e acadêmico.

Por sua vez, 59,09\% também optaram pelas opções nunca, raramente ou não sei quando perguntados se os servidores da própria organização eram encorajados pelos dirigentes a utilizar resultados de pesquisas. No mesmo sentido, 57,34\% dos respondentes selecionaram nunca, raramente ou náo sei quando questionados se sua organização oferecia oportunidades para construir relacionamentos com pesquisadores de universidades.

Os dois percentuais evidenciam que, da perspectiva organizacional, também não existem práticas positivas, seja no sentido de estimular a utilização de pesquisas, seja no sentido de criar linhas de diálogo com o campo científico-universitário.

Os índices obtidos para a variável aspectos individuais e organizacionais que impactam nas práticas de utilização de pesquisas são extremamente relevantes, porque sugerem a não existência de política ativa por parte da administração federal no sentido de incorporar e 
disseminar o paradigma das PPBEs. Embora os servidores reconheçam uma disponibilidade "eventual" de tempo e recursos para acessar informaçôes e evidências, do ponto de vista organizacional, quase não existem estímulos ou orientaçóes reforçando essa prática. Essa constatação se coaduna com o achado a seguir, de desconhecimento ou inexistência de unidades administrativas dedicadas à utilização de evidências.

Ademais, do ponto de vista individual, ainda que os servidores demonstrem alguma inclinação à utilização de evidências científicas para tomada de decisôes, também fica claro que essa inclinação não é materializada em diálogo permanente e direto com o campo acadêmico-científico.

Ao fim da seção temática sobre utilização de informações e evidências, as últimas variáveis analisadas foram a existência de unidade especializada na utilização de pesquisas no órgáo/ministério no qual o burocrata trabalha e as atribuiçôes dessa unidade, caso esta exista. A questão foi incluída com o propósito de mapear a presença de uma estrutura institucional voltada especificamente para a questão das evidências.

O gráfico 17 chama atenção para o fato de que a maior parte dos respondentes (43\%) afirmou que não sabia se tal unidade existia no próprio ministério. Ou seja, mesmo que tais unidades existissem, para grande parte dos servidores, estas náo estavam ao alcance - talvez inclusive por falta de divulgaçáo interna.

Como 29\% dos respondentes afirmaram que esse tipo de unidade náo existia na estrutura do órgão, na prática, $72 \%$ dos participantes do survey náo tinham acesso a uma unidade especializada na utilização de pesquisas científicas. Esse dado corrobora a variável anterior sobre fatores organizacionais, confirmando a ausência tanto de políticas quanto de estruturas institucionais voltadas ao estímulo e à disseminação da PPBE na burocracia federal. 
GRÁFICO 17

Existência de unidade especializada na utilização de pesquisas na estrutura do ministério (Em \%)

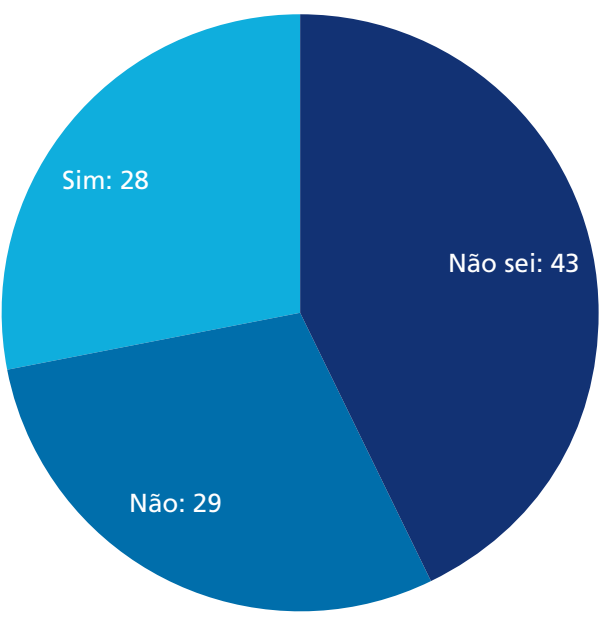

Fonte: Ipea.

Elaboração dos autores.

Para aqueles que confirmaram a existência da unidade em seu órgão, foi apresentada a segunda questão, com uma lista de atribuiçóes para que indicassem se estas eram executadas ou náo por aquela unidade. Os resultados encontrados (tabela 14) demonstram que as principais atribuições dessas estruturas especializadas são: Disseminar os resultados de pesquisas (70,5\%), Produção de pesquisas (65,5\%) e Prospectar pesquisas realizadas $(61,5 \%)$.

\section{TABELA 14}

Atribuições da unidade especializada'

(Em \%)

\begin{tabular}{ll}
\hline Atribuições & \\
\hline Disseminar os resultados de pesquisas & 70,5 \\
Produção de pesquisas & 65,5 \\
Prospectar pesquisas realizadas & 61,5 \\
Contratar pesquisas & 47,5 \\
Traduzir os resultados de pesquisa em recomendações & 37,3 \\
\hline
\end{tabular}

Fonte: Ipea.

Elaboração dos autores.

Nota: 'O respondente poderia marcar mais de uma opção. 


\subsection{Habilidades e valores}

Nesta quarta subseção, serão apresentados os resultados relativos às variáveis de habilidades e valores. Nesse sentido, foram feitas questôes referentes à percepção dos burocratas a respeito de sua capacidade analítica - isto é, seus conhecimentos e suas habilidades individuais, bem como seus valores e suas motivaçóes.

A primeira questão sobre o tema solicitava aos participantes que indicassem o grau de dificuldadelfacilidade que teriam para a realização das atividades listadas. Por meio de uma escala de 1 a 10, em que 1 significava muito difícil e 10, muito fácil, a questáo pretendia mapear a familiaridade dos burocratas com determinadas tarefas.

O gráfico 18 demonstra as tarefas mais difíceis/menos familiares por meio da presença das faixas mais escuras e as mais fáceis/mais familiares por intermédio das faixas mais claras.

Fica evidente que a tarefa mais difícil para os respondentes é a utilização de ferramentas e tecnologias de processamento de dados e de análise estatística. Em seguida, mas em menor intensidade, a definição de indicadores e metodologias para avaliaçáo e monitoramento aparece como outra tarefa difícil. Por sua vez, identificar, coletar e analisar dados e informaçôes parece ser tarefa bem mais familiar.

Ou seja, a análise de dados e informaçôes de forma genérica demonstra-se uma habilidade existente entre os burocratas, enquanto o exercício especializado com softwares de processamento/análise e indicadores se revela muito distante. Capacidades mais sofisticadas, portanto, são as menos presentes entre os respondentes. 
GRÁFICO 18

Nível de dificuldade/facilidade em realizar determinadas tarefas

(Em \%)

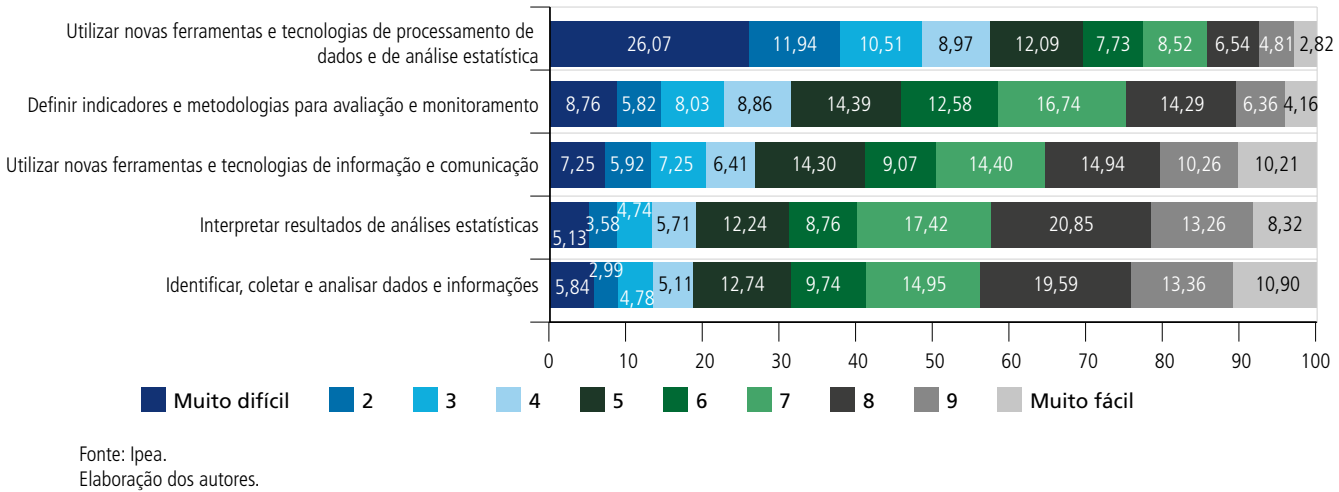

$\mathrm{Na}$ sequência, os respondentes foram questionados se realizaram algum treinamento ou capacitação de formação continuada - como cursos de curta duração, aperfeiçoamento, especialização, mestrado ou doutorado - nos últimos doze meses. Havia orientação para que indicassem cursos realizados tanto por iniciativa própria quanto por incentivo do órgão. Entre todos os participantes, 56,1\% responderam que sim e 39,9\%, que não.

Em seguida, àqueles que responderam sim, foi perguntado se no curso houve leitura de pesquisas e estudos científicos. O dado encontrado (gráfico 19) é extremamente relevante porque evidencia o caráter imprescindível de treinamentos e capacitaçóes de formação continuada para a expansão do acesso e utilização de evidências científicas por parte dos burocratas. Entre aqueles que participaram de cursos, $73 \%$ afirmaram ter lido pesquisas e estudos científicos na ocasião. 
GRÁFICO 19

Leitura de pesquisas e estudos científicos no curso de capacitação/formação continuada (Em \%)

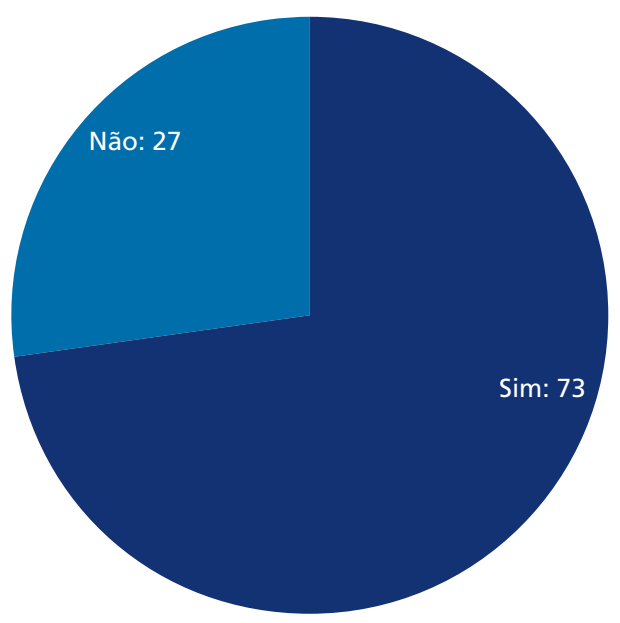

Fonte: Ipea.

Elaboração dos autores.

No mesmo bloco do questionário, também foi apresentada uma pergunta focada nas crenças e valores dos participantes no que tange às responsabilidades do Estado brasileiro. $\mathrm{Na}$ oportunidade, o respondente foi solicitado a indicar o quanto discordava ou concordava de uma série de sentenças a respeito do tema - em uma escala de 1 a 7 , o ponto 1 representava discordo totalmente e o 7 , concordo totalmente.

Como demonstrado no gráfico 20, os respondentes tendem a concordar principalmente como a ideia de que o Estado brasileiro deve combater com firmeza a desigualdade entre ricos e pobres, bem como com a perspectiva que o Estado deve ser o principal responsável pelo provimento dos serviços de saúde à população. Ademais, a maior parte dos burocratas discorda da assertiva que aponta que o Estado deveria ser dono das principais empresas e indústrias do país. Os dados revelam que, em geral, os respondentes apresentam um perfil favorável a uma maior intervenção estatal em questóes sociais - como a desigualdade socioeconômica entre os diferentes grupos da sociedade e o acesso da população à saúde - e menor intervenção em questóes econômicas (controle de empresas e criação de empregos serem responsabilidades mais ligadas ao setor privado). 
GRÁFICO 20

Nível de concordância com diferentes perspectivas a respeito do Estado brasileiro (Em \%)

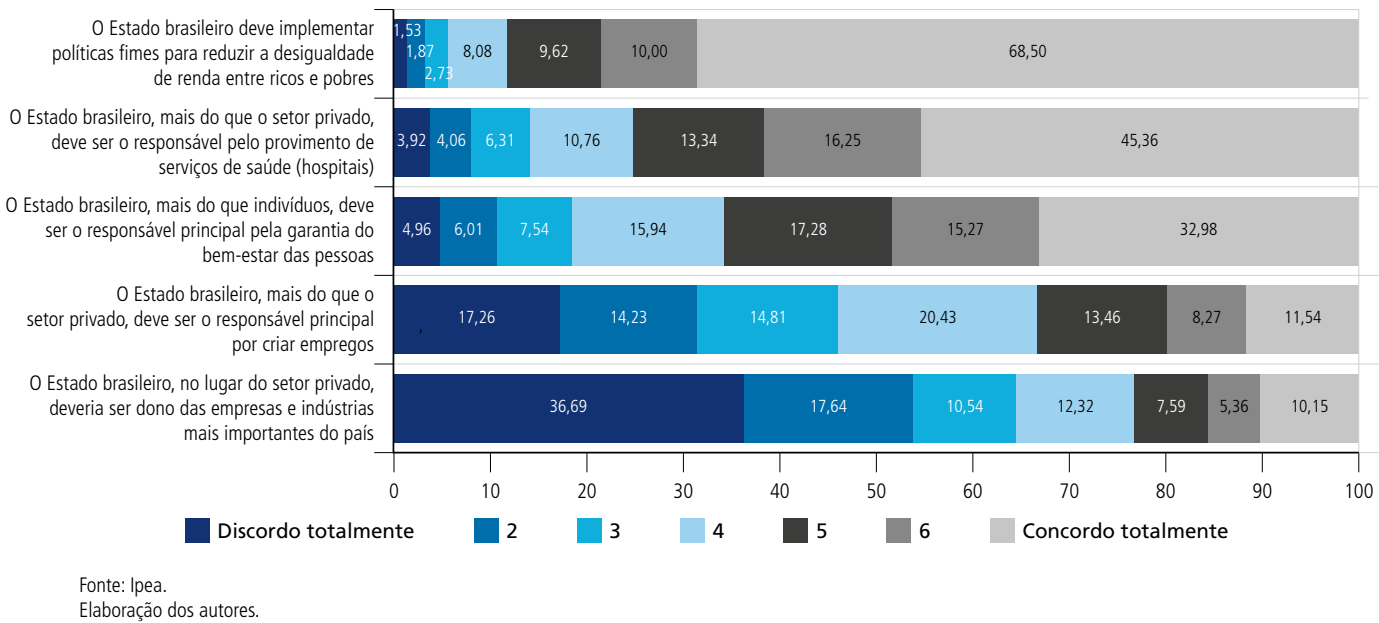

\section{CONSIDERAÇÕES FINAIS}

A elaboração de uma pesquisa dessa natureza compreende alguns ganhos analíticos e permite inferências que em outros estudos são apenas conjecturas. Compreender o espaço de atuação e as consequências de diferentes estratégias de obtenção de recursos informacionais é um elemento importante para conhecer o processo decisório e comportamental no âmbito da administração pública. A utilização de um survey on-line possibilita, por um custo relativamente baixo, ampliar o escopo de análise, abarcando respondentes de diferentes carreiras, funçóes desempenhadas e provenientes de diferentes espaços de trabalho.

Nesse sentido, um primeiro destaque dos resultados obtidos é a compreensão das diferentes funçóes desempenhadas pelos servidores públicos federais no processo de produção de políticas públicas. Há forte caráter analítico nas funçôes desempenhadas pelos burocratas federais. São muito relevantes atividades dedicadas a assessoramento, interlocução com os órgãos de controle e análise de documentos e dados, com o propósito de levantar ou até mesmo produzir informações confiáveis no âmbito das políticas públicas. Outra função comumente desempenhada tem atributos relacionais em maior destaque, como a contratação e a validação de estudos e avaliaçóes de políticas públicas, a representação externa do órgão, a captação de recursos e a coordenação de equipes. Há ainda um perfil de servidores dedicados à fiscalização de contratos e ao monitoramento 
de políticas públicas e outro perfil mais propriamente voltado a atividades administrativas. A pesquisa realizada permite a observação de um perfil que se repete em relação ao survey anterior (Enap, 2018), que simultaneamente compreende aspectos analíticos e a interlocução com os órgãos de controle.

Quando se observam os tipos de informação utilizados pelos servidores federais, notam-se, em primeiro lugar, quatro tipos diferentes de recursos informacionais mobilizados. O primeiro tem natureza de fontes internas ao Estado brasileiro - como leis, normas, pareceres, recomendaçôes de órgáos de controle, bem como a produção de informaçôes a partir de bases de dados governamentais. O segundo remeterá a fontes externas, que vão de boas práticas de estados e municípios a recomendaçôes de instâncias participativas, usuários e grupos de interesse. $\mathrm{O}$ terceiro trata dos recursos informacionais baseados em pesquisa científica (artigos, capítulos e relatório de pesquisa). Por fim, o quarto aborda informaçôes provenientes de experiência pessoal ou de colegas de trabalho. Chama atenção o longo rol de informações provenientes do próprio Estado, o que remete para o caráter endógeno do conhecimento mobilizado para subsidiar o processo decisório, típico de burocracias públicas que mobilizam o conhecimento racional-legal. Esse dado desafia a abordagem da PPBE na medida em que demonstra que diversas fontes informam as políticas públicas no caso brasileiro, sendo as evidências produzidas pela própria administraçáo pública as de maior relevância.

Especificamente quanto à utilizaçâo de evidências cientificas, foram apresentados aos respondentes um conjunto de alternativas relacionadas a fatores que poderiam potencialmente favorecer sua utilizaçáo, como fonte e aplicabilidade dos conteúdos, até sua extensão e seu apelo visual. Os dois fatores mais relevantes foram a credibilidade e o prestígio da fonte, por um lado, bem como a aplicabilidade dos estudos produzidos, por outro. A atratividade visual do trabalho, assim como sua extensão, não foi apontada como tão importante, não obstante que a facilidade da compreensão da pesquisa tenha sido considerada um fator de importância intermediária.

Do ponto de vista organizacional, não foram observadas muitas estratégias para incorporação e disseminação de uma ênfase de PPBEs, havendo poucos canais de diálogo formal e intermediação com a academia. Menos de um terço dos respondentes identificou a existência de alguma estrutura organizacional dedicada à interlocução com estudiosos e acadêmicos. Chama atenção, ainda, o fato de $43 \%$ dos respondentes não saber dizer se tal estrutura existia em seu órgão, o que novamente sinaliza baixa institucionalização ou disseminação de uma cultura de PPBEs nas organizaçóes federais. Os dados indicam capacidades e atividades individuais para utilizar evidências científicas no processo 
decisório, embora não necessariamente inseridas em lógica formal ou permanente de parceria com universidades e instituiçóes de pesquisa.

Uma discussão que emerge das análises remete ao relacionamento que se estabelece entre gestão pública e academia. Há alguns elementos que apontam para a hipótese de duas comunidades, como a existência de baixa interlocução formal entre essas esferas da sociedade. No caso dos dados levantados, observa-se certa endogenia do conhecimento utilizado pela máquina pública, proveniente muitas vezes de normativos ou dados produzidos pelas próprias políticas públicas. No entanto, não seria adequado caracterizar que há barreiras intransponíveis entre gestores e pesquisadores. Do ponto de vista individual, é elevado o nível de educação formal da APF, havendo esforços específicos de valorização e interlocução com a academia. Além disso, não se pode caracterizar que até mesmo a produção de evidências provenientes do próprio Estado náo seja eivada de conhecimento científico, o que possibilitaria a utilização ao menos indireta de produçóes acadêmicas no conhecimento endógeno realizado pelo aparato estatal.

Tendo-se em vista esses elementos da pesquisa, observa-se como próximo passo a construção de análises de cunho inferencial que possam dialogar com a literatura existente, em particular traçar correlaçóes sobre os aspectos individuais e organizacionais que podem interferir na utilização de evidências científicas e de outras naturezas. Ademais, sustenta-se que a investigação dos dados sobre outros tipos de evidências poderá ser explorada em diálogo com abordagens teóricas críticas à visão da racionalidade instrumental nas políticas públicas, a fim de subsidiar a discussão sobre os limites e as possibilidades do paradigma da PPBE.

Essa base de dados é muito rica nesse sentido, possibilitando sua utilização com o propósito de investigar com maior profundidade as diversas dimensóes inscritas no modelo teórico sintetizado na figura 1. Permite explorar questôes em diálogo com perguntas apontadas pela literatura de políticas públicas, tais como: diferentes tipos de funçóes de políticas públicas fazem uso de diferentes fontes de evidências? Perfis funcionais ou até mesmo sociodemográficos dos burocratas indicariam preferências distintas de tipos de evidências? Padrôes de relaçốes explicariam acessos diferenciados aos vários tipos de evidências? E valores também condicionariam as preferências e os usos das evidências? De maneira geral, o que levaria a burocracia a dar maior reconhecimento à sua própria produção e experiência? A capacidade analítica individual permitiria que a produção interna seja alimentada pelas evidências científicas? Há interaçôes entre os diferentes tipos de evidências? Quando se faz uso de evidências científicas de forma mais direta, qual o tipo de uso predominaria e em que circunstâncias? 
Estudos comparativos com os resultados dos surveys que embasaram a construção do instrumento desta pesquisa também são vislumbrados, com o intuito de alargar a compreensão acerca das características da produção das políticas públicas no Brasil, como o achado aparentemente atípico da relação da função analítica com a de controle. Vale lembrar que os dados desta pesquisa foram coletados no final da gestáo anterior e foram comparados, em alguma medida, com dados da pesquisa realizada em 2017 (Enap, 2018), início também da gestão anterior. Isto é, trata-se de um retrato de aspectos da função analítica da burocracia federal daquele governo. Portanto, para avançar nessa agenda de pesquisa mais ampliada, seria interessante, no horizonte de longo prazo, ter novas ondas de surveys com periodicidade regular para identificar mudanças, tendências e condicionantes da dinâmica de produção de políticas públicas no Brasil.

Por fim, espera-se que este trabalho contribua para o adensamento do conhecimento sobre as capacidades e as dinâmicas estatais de produçáo de políticas, especialmente quanto à cultura decisória e à função analítica do Estado no enfrentamento de problemas crescentemente complexos. Talvez os desafios impostos pela pandemia global do coronavírus, que fazem contrastar a avalanche de novas evidências - de natureza científica ou não - geradas a todo instante e utilizadas para informar rumos e medidas de governos em todo o mundo, constituam relevante justificativa para a continuidade dessa agenda de pesquisa.

\section{REFERÊNCIAS}

AMARA, N.; OUIMET, M.; LANDRY, R. New evidence on instrumental, conceptual, and symbolic utilization of university research in government agencies. Science Communication, v. 26, n. 1, p. 75-106, 2004.

BEYER, J. M. Research utilization: bridging the gap between communities. Journal of Management Inquiry, v. 6, n. 1, p. 17-22, 1997.

CAIRNEY, P. The UK government's imaginative use of evidence to make policy. British Politics, v. 14, n. 1, p. 1-22, 2019.

CAVALCANTE, P.; LOTTA, G. Burocracia de médio escaláo: perfil, trajetória e atuação. Brasília: Enap, 2015.

CHERNEY, A. et al. Use of academic social research by public officials: exploring preferences and constraints that impact on research use. Evidence \& Policy: a journal of research, debate and practice, v. 11, n. 2, p. 169-188, 2015. 
COHEN, D.; LINDBLOM, C. Solving problems of bureaucracy: limits on social science. American Behavioral Scientist, v. 22, n. 5, p. 547-560, May 1979.

COHEN, M.; MARCH, J.; OLSEN, J. A garbage can model of organizational choice. Administrative Science Quarterly, v. 17, n. 1, p. 1-25, Mar. 1972.

COLEBATCH, H. K.; HOPPE, R.; NOORDEGRAAF, M. Working for policy. Amsterdam: Amsterdam University Press, 2010.

DAVIES, H. T. O.; NUTLEY, S.; SMITH, P. What works? Evidence-based policy and practice in public services. Bristol: The Policy Press, 2000.

DELEON, P. The historical roots of the field. Oxford: Oxford University Press, 2008. Disponível em: <https://bit.ly/3maRpZW>. Acesso em: 17 abr. 2020.

ENAP - ESCOLA NACIONAL DE ADMINISTRAÇÃO PÚBLICA. Capacidades estatais para produçáo de políticas públicas: resultados do survey sobre serviço civil no Brasil. Brasília: Enap, 2018. (Cadernos Enap, n. 56).

FARAH, M. Abordagens teóricas no campo de política pública no Brasil e no exterior: do fato à complexidade. Revista do Serviço Público, v. 69, p. 53-84, 2018.

FISCHER, F.; GOTTWEIS, H. The argumentative turn revisited: public policy as communicative practice. Durham; London: Duke University Press, 2012.

FLEISCHER, J. Power resources of parliamentary executives: policy advice in the UK and Germany. West European Politics, v. 32, n. 1, p. 196-214, 2008.

HOWLETT, M.; LINDQUIST, E. Policy analysis and governance: analytical and policy styles in Canada. Journal of Comparative Policy Analysis: Research and Practice, v. 6, n. 3, p. 225-249, 2004.

LASSWELL, H. D.; LERNER, D. (Orgs.), The policy sciences: recent developments in scope and method. Stanford: Stanford University Press, 1951.

LEJANO, R. P. Framework for policy analysis: merging text and context. New York: Taylor \& Francis Goup, 2006.

LINDBLOM, E. The science of muddling through public administration. Public Administration Review, v. 19, n. 2, p. 79-88, 1959.

MACEDO, A. S.; VIANA, R.; NASCIMENTO, M. Capacidades analíticas no processo de produção de políticas públicas: quais fontes de evidências utilizam o serviço civil da administração pública federal? Administraçáo Pública e Gestáo Social, v. 4, n. 11, p.1-22, 2019.

MELTSNER, A. Policy analysts in the bureaucracy. Berkeley: University of California Press, 1976. 
NEWMAN, J.; CHERNEY, A.; HEAD, B. W. Do policy makers use academic research? Reexamining the "two communities": theory of research utilization. Public Admin Review, v. 76, n. 1, p. 24-32, Jan./Feb. 2016.

OLIVER, K. et al. A systematic review of barriers to and facilitators of the use of evidence by policymakers. BMC Health Services Research, v. 14, n. 1, p. 1-12, 2014.

OUIMET, M. et al. The absorption of research knowledge by public civil servants. Evidence \& Policy: A Journal of Research, Debate and Practice, v. 5, n. 4, p. 331-350, Nov. 2009.

PAINTER, M.; PIERRE, J. (Orgs.) Challenges to State policy capacity: global trends and comparative perspectives. Basingstoke: Palgrave Macmillan, 2005.

PARKHURST, J. The politics of evidence: from evidence-based policy to the good governance of evidence. London: Routledge, 2017.

PINHEIRO, M. M. S. Políticas públicas baseadas em evidências (PPBEs): delimitando o problema conceitual. Rio de Janeiro: Ipea, abr. 2020. (Texto para Discussão, n. 2554).

Políticas públicas baseadas em evidências: uma avaliação crítica. Rio de Janeiro: Ipea. No prelo.

PIRES, R.; LOTTA, G.; OLIVEIRA, V. E. Burocracia e políticas públicas no Brasil: intersecções analíticas. Brasília: Ipea; Enap, 2018.

SPINK, P. Beyond public policy: a public action languages approach. Northampton: Edward Elgar Publishing, 2019.

VAITSMAN, J.; RIBEIRO, J.; LOBATO, L. Policy analysis in Brazil: the state of the art. In: VAITSMAN, J.; RIBEIRO, J.; LOBATO, L. (Orgs.). Policy analysis in Brazil. Chicago: Chicago University Press, 2013. p. 1-10.

VESELÝ, A.; OCHRANA, F.; NEKOLA, M. When evidence is not taken for granted: the use and perception of "evidence" in the czech republic ministries. NISPAcee Journal of Public Administration and Policy, v. 11, n. 2, p. 219-234, 2018.

WEBER, M. Burocracia. In: WEBER, M. Ensaios de sociologia. Rio de Janeiro: Zahar, 1963. p. $230-281$.

WILDAVSKY, A. B. Speaking truth to power: the art and craft of policy analysis. Boston: Little-Brown, 1979.

WU, X.; RAMESH, M.; HOWLETT, M. Policy capacity: a conceptual framework for understanding policy competences and capabilities. Policy and Society Associates, v. 221, n. 3-4, p. 165-171, Sept./Dec. 2015. 


\section{APÊNDICE A}

\section{ANÁLISES FATORIAIS}

Nas análises fatoriais realizadas para os dados das variáveis que compõem a seção função na política pública e fontes de informação, três critérios de retenção de número de fatores foram comparadas para se chegar à melhor decisão: o critério de Kaiser, que retém o número de fatores quando estes atingem o autovalor maior que 1 ; o critério da variância acumulada, que retém o número de fatores quando atingem a capacidade de explicar mais de $60 \%$ da variabilidade dos dados; e o critério da análise paralela, que simula projeção com objetivo de sugerir o máximo de fatores que podem ser retidos, a partir da ajuda em tirar parte da subjetividade da interpretaçáo do scree plot. Conforme apresentado na tabela A.1, o critério de Kaiser e o critério da variância acumulada sugerem a retençấo de três fatores. Conforme o gráfico A.1, o critério da análise paralela sugere a retenção de até seis fatores.

TABELA A.1

Resultados de retenção de fatores a partir dos critérios de Kaiser e da variância acumulada (função na política pública)

\begin{tabular}{lccc}
\hline Componente principal & Autovalor & $\begin{array}{c}\text { Variância } \\
(\%)\end{array}$ & $\begin{array}{c}\text { Cumulativa } \\
(\%)\end{array}$ \\
\hline 1 & 6,226 & 44,47 & 44,47 \\
2 & 1,223 & 8,74 & 53,21 \\
3 & 1,120 & 8,00 & 61,21 \\
4 & 0,967 & - & - \\
\hline$\quad$ Fonte: Ipea. & & &
\end{tabular}




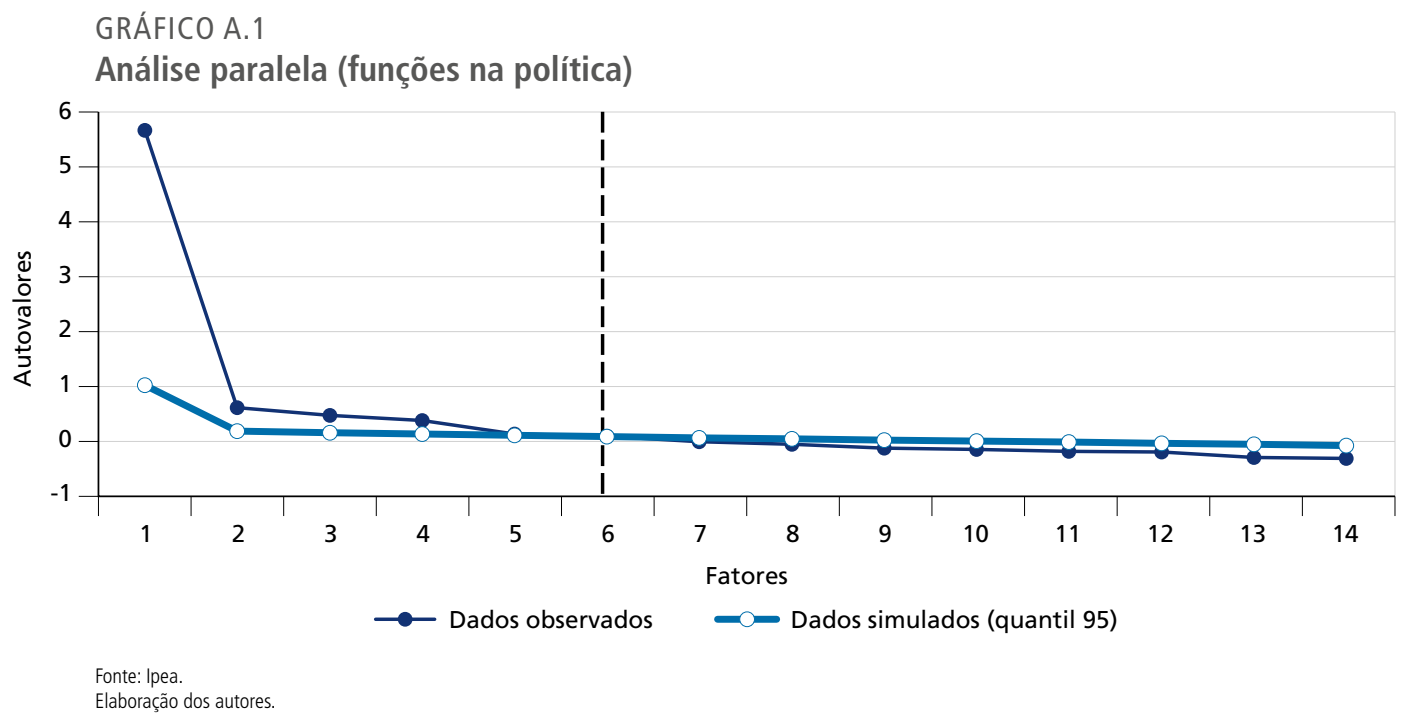

Comparando-se o resultado dos critérios, pode-se concluir que a decisão entre três e seis fatores é plausível. A escolha pela retenção de quatro fatores deu-se por uma expectativa teórica, fundamentada em estudos anteriores, a qual espera que a realidade subjacente aos dados se defina satisfatoriamente em quatro fatores. A partir do gráfico A.1, é perceptível que a retenção de mais que quatro fatores (cinco ou seis) promove um ganho minimamente perceptível levando em conta autovalores simulados. Portanto, a análise fatorial exploratória (AFE) usando quatro fatores mostra-se parcimoniosa, ao mesmo tempo que explica grande parte da variação dos dados.

Por decisão de representar mais a realidade, a variável coordenar equipe foi deslocada intencionalmente do quarto fator para o primeiro fator - para o qual gerou a segunda maior carga fatorial. Essa variável, inclusive, obteve cargas fatoriais de valor baixo. A partir dessa decisão, o quarto fator ficou formado apenas de uma variável: realizar atividades administrativas, tais como agendamento de reuniōes, tramitação de processos, compra de passagens, elaboração de ofícios e memorandos. Reconhecemos que a formação de fator com apenas uma questáo (variável) pode ser questionável, porque reduz uma variável latente (fator) a uma variável diretamente observável. Tipicamente, um fator é caracterizado pela sua influência sobre um conjunto de variáveis observáveis, sendo o tamanho desse conjunto relacionado à sua complexidade. No entanto, observamos que essa atipicidade contemplou um fator que traduz a divisão de hierarquia na burocracia federal: há uma "classe" de servidores que realizam quase que somente atividades administrativas. Ou seja, mesmo que atípico, o fator formado por uma variável contempla a realidade a qual está submetido. 
Para os dados de fontes de informação, ambos os critérios de Kaiser e da variância acumulada sugerem a retenção de três fatores, conforme a tabela A.2.

TABELA A.2

Resultados de retenção de fatores a partir dos critérios de Kaiser e da variância acumulada (fonte de informação)

\begin{tabular}{lccc}
\hline Componente principal & Autovalor & $\begin{array}{c}\text { Variância } \\
(\%)\end{array}$ & $\begin{array}{c}\text { Cumulativa } \\
(\%)\end{array}$ \\
\hline 1 & 6,059 & 40,391 & 40,391 \\
2 & 2,598 & 17,322 & 57,713 \\
3 & 1,266 & 8,439 & 66,153 \\
4 & 0,873 & - & - \\
\hline
\end{tabular}

Fonte: Ipea.

Elaboração dos autores.

Os autovalores representados no gráfico A.2 sugerem que a retenção de mais que quatro fatores não contribuem no aumento da variância explicada pela AFE. Ao mesmo tempo, a análise paralela sugere a retenção de no máximo quatro fatores. Observando-se a matriz de correlaçáo dos dados, notou-se um padrão sugestivo da existência de quatro fatores. Sendo assim, decidiu-se pela extração desse número de fatores.

GRÁFICO A.2

Análise paralela (fontes de informação)

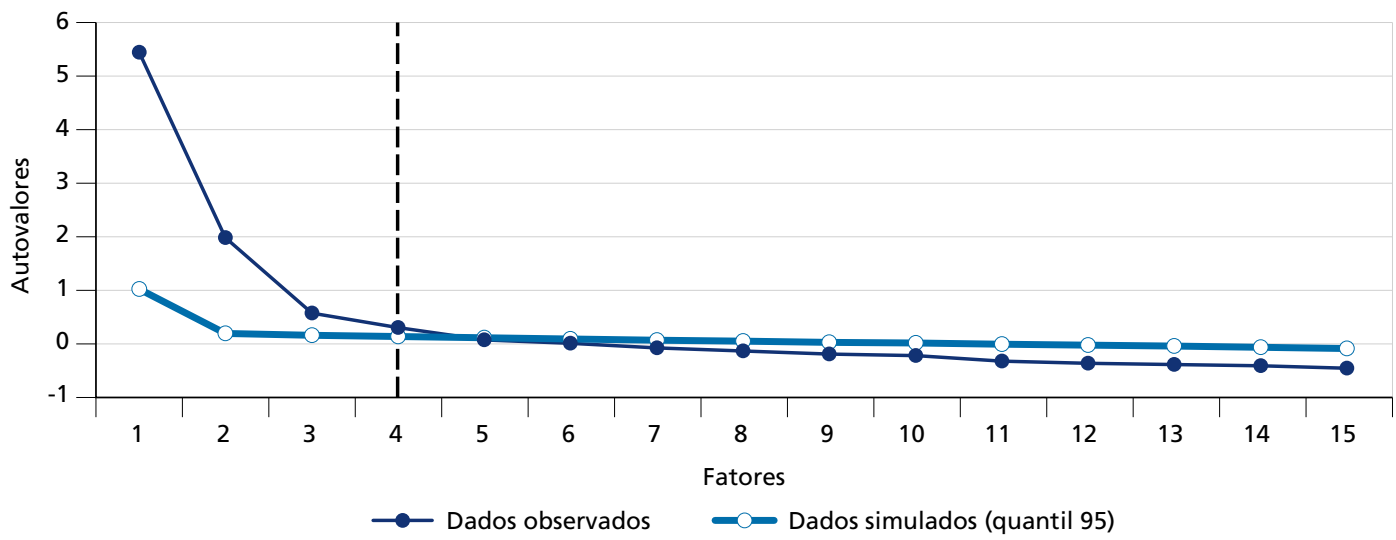

Fonte: Ipea.

Elaboração dos autores.

Como partimos do pressuposto de que os fatores gerados são independentes, a rotação varimax foi escolhida. Essa rotação é do tipo ortogonal e pressupóe tal autonomia. Tão importante quanto determinar o número de fatores é justificar teoricamente a premissa de que estes são independentes, garantindo-se que o uso de uma rotação 
ortogonal é adequado. Apesar de não ser muito rígida, partimos do pressuposto de que o serviço federal brasileiro pode ser definido a partir de funçóes que caracterizam sua hierarquia formal, entre outras questôes demográficas envolvidas, como escolaridade. Ou seja, não que todos não possam exercer uma função típica relacional ou analítica, mas há quem faça mais frequentemente uma função que outra. E isso se aplica também ao uso de tipos de informação.

Por fim, apesar de não haver nenhuma perda de variável, escolhemos o critério de formar fatores aquelas variáveis com carga fatorial acima de 0,3. Hair et al. (1998, p. 112) apresenta uma tabela indicando que as cargas fatoriais acima de 0,3 são de significância prática para um tamanho amostral acima de 300. Nossas AFEs estão de acordo com esse critério. No entanto, em algumas questóes, especialmente relacionadas às funçôes na política pública, as diferenças entre as cargas ao longo dos fatores são baixas. Dessa forma, os fatores podem não ser estáveis. Mas, se o nosso objetivo é resumir os dados, tal possível instabilidade pode ser um ponto de discussão que eleva a compreensão das informaçóes.

\section{REFERÊNCIA}

HAIR J. F. et al. Multivariate data analysis. London: Prentice-Hall, 1998. 


\section{ANEXO A}

\section{QUESTIONÁRIO}

\section{O QUE INFORMA AS POLÍTICAS PÚBLICAS FEDERAIS?}

\section{Seção A - Localização funcional}

QA1 - QUAL O SEU VÍNCULO COM A ADMINISTRAÇÃO PÚBLICA FEDERAL?

1) Servidor(a) público(a) efetivo(a)

2) Sem vínculo (cargo em comissão)

3) Aposentado(a) pela administração pública federal

4) Requisitado(a) de outros poderes (Legislativo ou Judiciário) e/ou esferas (estadual ou municipal), incluindo aposentados

5) Empregado(a) público(a) (empresas públicas e sociedades da economia)

QA2 - QUAL SUA CARREIRA ATUAL?

1) Administrador

2) Advogado da União

3) Agente administrativo

4) Agente de inspeção sanitária e industrial de produto de origem animal

5) Agente federal de execução penal

6) Analista ambiental

7) Analista em ciência e tecnologia

8) Analista de comércio exterior

9) Analista de infraestrutura

10) Analista de planejamento e orçamento

11) Analista do seguro social

12) Analista em tecnologia da informação do PGPE

13) Analista técnico-administrativo

14) Analista técnico de políticas sociais 
15) Analista tributário da Receita Federal do Brasil

16) Arquiteto

17) Assistente de chancelaria

18) Assistente em ciência e tecnologia

19) Assistente técnico-administrativo

20) Auditor-fiscal da Receita Federal do Brasil

21) Auditor-fiscal do trabalho

22) Auditor federal de finanças e controle

23) Auditor-fiscal federal agropecuário do Mapa

24) Auxiliar de enfermagem

25) Cargos de nível intermediário da carreira da seguridade social e do trabalho

26) Cargos de nível intermediário do PGPE

27) Cargos de nível superior do PGPE

28) Cargos de nível intermediário do Plano Especial de Cargos da Cultura

29) Cargos de nível superior do Plano Especial de Cargos da Cultura

30) Cargos de nível intermediário do Plano Especial de Cargos do Ministério do Meio Ambiente e do Ibama

31) Cargos de nível superior do Plano Especial de Cargos do Ministério do Meio Ambiente e do Ibama

32) Contador

33) Datilografo

34) Diplomata

35) Economista

36) Enfermeiro

37) Engenheiro

38) Engenheiro agrônomo

39) Especialista em políticas públicas e gestão governamental

40) Médico

41) Militar 
42) Motorista oficial

43) Oficial de chancelaria

44) Pesquisador da carreira de pesquisa em ciência e tecnologia

45) Procurador da Fazenda Nacional

46) Técnico de nível superior

47) Técnico do seguro social

48) Técnico em assuntos educacionais

49) Técnico federal de finanças e controle

50) Tecnologista

51) Tecnologista da carreira de desenvolvimento tecnológico

52) Técnico em atividade hospitalares

53) Cargo de nível intermediário - empresa pública

54) Cargo de nível superior - empresa pública

55) Outros cargos de nível intermediário - Atividades administrativas e operacionais

56) Outros cargos de nível auxiliar - atividades administrativas e operacionais

57) Outros cargos técnicos - nível médio

58) Outros cargos técnicos - nível superior

59) Outros cargos de pesquisador

60) Outros cargos de nível superior

61) Outros cargos de nível intermediário

62) Outros cargos de nível auxiliar

63) Outros

999 Sem resposta

-888 Não se aplica

QA3 - HÁ QUANTOS ANOS VOCÊ FAZ PARTE DESTA CARREIRA?

Entrada numérica: 0 A 99

999 Sem resposta

-888 Não se aplica 
QA4 - ATUALMENTE, VOCÊ OCUPA ALGUM CARGO DE DIREÇÃO E ASSESSORAMENTO SUPERIOR (DAS) OU EQUIVALENTE (CARGO COMISSIONADO EM UMA AGÊNCIA REGULADORA OU EMPRESA PÚBLICA)?

0 Não

1 Sim

999 Sem resposta

-888 Não se aplica

QA5 - QUAL O NÍVEL DO CARGO DE DAS OU EQUIVALENTE QUE VOCÊ OCUPA ATUALMENTE?

1) DAS-1 (ou CAS I, CAS II, CCT II, CCT I)

2) DAS-2 (ou CA III, CCT III)

3) DAS-3 (ou CGE IV, CCT IV)

4) DAS-4 (ou CGE II, CGE III, CA I, CA II, CCT V)

5) DAS-5 (ou CGE I)

6) DAS-6 (ou CD I, CD II)

7) FCPE-1

8) FCPE-2

9) FCPE-3

10) FCPE-4

999 Sem resposta

-888 Não se aplica

QAOA - AO LONGO DE SUA VIDA PROFISSIONAL, INCLUINDO SEU CARGO ATUAL, INDIQUE SE TRABALHOU NOS TIPOS DE ORGANIZAÇÃO LISTADOS ABAIXO, INFORMANDO QUANTOS ANOS EM CADA ORGANIZAÇÃO.

QA6 - PODER PÚBLICO FEDERAL

0 Nunca trabalhou

1 Menos de 3 anos

2 Entre 3 e 5 anos

3 Entre 5 e 7 anos

4 Entre 7 e 10 anos

5 Acima de 10 anos 
999 Sem resposta

QA7 - PODER PÚBLICO ESTADUAL OU DISTRITAL

0 Nunca trabalhou

1 Menos de 3 anos

2 Entre 3 e 5 anos

3 Entre 5 e 7 anos

4 Entre 7 e 10 anos

5 Acima de 10 anos

999 Sem resposta

QA8 - PODER PÚBLICO MUNICIPAL

0 Nunca trabalhou

1 Menos de 3 anos

2 Entre 3 e 5 anos

3 Entre 5 e 7 anos

4 Entre 7 e 10 anos

5 Acima de 10 anos

999 Sem resposta

QA9 - EMPRESA PÚBLICA E SOCIEDADE DE ECONOMIA MISTA

0 Nunca trabalhou

1 Menos de 3 anos

2 Entre 3 e 5 anos

3 Entre 5 e 7 anos

4 Entre 7 e 10 anos

5 Acima de 10 anos

999 Sem resposta

QA10 - EMPRESA PRIVADA

0 Nunca trabalhou

1 Menos de 3 anos 
2 Entre 3 e 5 anos

3 Entre 5 e 7 anos

4 Entre 7 e 10 anos

5 Acima de 10 anos 999 Sem resposta

QA11 - ENTIDADE SEM FINS LUCRATIVOS

0 Nunca trabalhou

1 Menos de 3 anos

2 Entre 3 e 5 anos

3 Entre 5 e 7 anos

4 Entre 7 e 10 anos

5 Acima de 10 anos

999 Sem resposta

QA12 - ORGANISMO INTERNACIONAL

0 Nunca trabalhou

1 Menos de 3 anos

2 Entre 3 e 5 anos

3 Entre 5 e 7 anos

4 Entre 7 e 10 anos

5 Acima de 10 anos

999 Sem resposta

QA13 - UNIVERSIDADE E INSTITUTOS DE PESQUISA

0 Nunca trabalhou

1 Menos de 3 anos

2 Entre 3 e 5 anos

3 Entre 5 e 7 anos

4 Entre 7 e 10 anos

5 Acima de 10 anos

999 Sem resposta 
QA14 - EM QUE MINISTÉRIO OU ÓRGÃO SUPERIOR VOCÊ TRABALHA ATUALMENTE?

1) Advocacia-Geral da União

2) Assessoria Especial do Presidente da República

3) Autoridade Nacional de Proteção de Dados

4) Casa Civil da Presidência da República

5) Controladoria-Geral da União

7) Gabinete Pessoal do Presidente da República

8) Gabinete de Segurança Institucional da Presidência da República

9) Ministério da Agricultura, Pecuária e Abastecimento

10) Ministério da Cidadania

11) Ministério da Ciência, Tecnologia, Inovaçôes e Comunicaçóes

12) Ministério da Defesa

13) Ministério da Economia

14) Ministério da Educação

15) Ministério da Infraestrutura

16) Ministério da Justiça e Segurança Pública

17) Ministério da Mulher, da Família e dos Direitos Humanos

18) Ministério da Saúde

19) Ministério das Relaçóes Exteriores

20) Ministério de Minas e Energia

21) Ministério do Desenvolvimento Regional

22) Ministério do Meio Ambiente

23) Ministério do Turismo

24) Secretaria de Governo da Presidência da República

25) Secretaria-Geral da Presidência da República

26) Vice-Presidência da República

999 Sem resposta 
QA15 - EM QUAL UNIDADE DO MINISTÉRIO OU ÓRGÃO VINCULADO?

1) AG1 Consultoria-Geral da União

2) AG2 Corregedoria-Geral da Advocacia da União

3) AG3 Departamento de Gestão Estratégica

4) AG6 Procuradoria-Geral da União

5) AG7 Procuradoria-Geral Federal

6) AG8 Secretaria-Geral de Administração

7) AG99 Outros

8) CC1 Instituto Nacional de Tecnologia da Informação

9) CC10 Subchefia de Análise e Acompanhamento de Políticas Governamentais

10) CC5 Gabinete do Ministro

11) CC8 Secretaria Executiva

12) CC9 Secretaria Especial do Programa de Parcerias de Investimento

13) CC99 Outros

14) CG10 Unidades colegiadas

15) CG2 Consultoria Jurídica

16) CG3 Gabinete

17) CG4 Secretaria Executiva

18) CG5 Corregedoria-Geral da Uniâo

19) CG6 Ouvidoria-Geral da União

20) CG7 Secretaria Federal de Controle Interno

21) CG8 Secretaria de Combate à Corrupção

22) CG9 Secretaria de Transparência e Prevenção da Corrupção

23) CG99 Outros

24) MA1 Centrais de Abastecimento de Minas Gerais S.A.

25) MA10 Corregedoria-Geral

26) MA12 Secretaria Executiva

27) MA13 Comissão Executiva do Plano da Lavoura Cacaueira

28) MA14 Instituto Nacional de Meteorologia 
29) MA16 Secretaria de Agricultura Familiar e Cooperativismo

30) MA17 Secretaria de Aquicultura e da Pesca

31) MA18 Secretaria de Comércio e Relações Internacionais

32) MA19 Secretaria de Defesa Agropecuária

33) MA20 Secretaria de Inovação, Desenvolvimento Rural e Irrigação

34) MA21 Secretaria de Política Agrícola

35) MA22 Serviço Florestal Brasileiro

36) MA23 Unidades colegiadas

37) MA6 Instituto Nacional de Colonização e Reforma Agrária

38) MA9 Consultoria jurídica

39) MA99 Outros

40) MCid10 Assessoria Especial de Comunicação Social

41) MCid13 Corregedoria-Geral

42) MCid14 Gabinete do Ministro

43) MCid15 Secretaria Executiva

44) MCid16 Secretaria Especial de Cultura

45) MCid17 Secretaria Especial do Desenvolvimento Social

46) MCid18 Secretaria Especial do Esporte

47) MCid20 Secretaria de Avaliação e Gestão da Informação

48) MCid21 Escritório Regional do Nordeste

49) MCid23 Escritório Regional do Sudeste

50) MCid99 Outros

51) MCid1 Agência Nacional do Cinema

52) MCid4 Fundação Cultural Palmares

53) MCid6 Instituto Brasileiro de Museus

54) MCid7 Instituto do Patrimônio Histórico e Artístico Nacional

55) MCid9 Assessoria Especial de Assuntos Internacionais

56) MCT1 Agência Espacial Brasileira 
57) MCT10 Assessoria Especial de Controle Interno

58) MCT11 Consultoria Jurídica

59) MCT12 Gabinete do Ministro

60) MCT13 Secretaria Executiva

61) MCT15 Secretaria de Empreendedorismo e Inovação

62) MCT16 Secretaria de Planejamento, Cooperação, Projetos e Controle

63) MCT17 Secretaria de Políticas para Formação e Ações Estratégicas

64) MCT19 Secretaria de Tecnologias Aplicadas

65) MCT2 Agência Nacional de Telecomunicaçóes

66) MCT20 Secretaria de Telecomunicaçóes

67) MCT21 Centro Brasileiro de Pesquisas Físicas

68) MCT22 Centro Nacional de Monitoramento e Alertas de Desastres Naturais

69) MCT23 Centro de Tecnologia Mineral

70) MCT24 Centro de Tecnologia da Informação Renato Archer

71) MCT25 Centro de Tecnologias Estratégicas do Nordeste

72) MCT26 Instituto Brasileiro de Informação em Ciência e Tecnologia

73) MCT27 Instituto Nacional da Mata Atlântica

74) MCT29 Instituto Nacional de Pesquisas Espaciais

75) MCT30 Instituto Nacional de Pesquisas da Amazônia

76) MCT31 Instituto Nacional de Tecnologia

77) MCT33 Instituto Nacional do Semiárido

78) MCT34 Laboratório Nacional de Astrofísica

79) MCT35 Laboratório Nacional de Computação Científica

80) MCT36 Museu Paraense Emílio Goeldi

81) MCT37 Museu de Astronomia e Ciências Afins

82) MCT38 Observatório Nacional

83) MCT4 Comissão Nacional de Energia Nuclear

84) MCT5 Conselho Nacional de Desenvolvimento Científico e Tecnológico 
85) MCT99 Outros

86) MD10 Secretaria de Pessoal, Ensino, Saúde e Desporto

87) MD11 Secretaria de Produtos de Defesa

88) MD12 Estado-Maior Conjunto das Forças Armadas

89) MD14 Escola Superior de Guerra

90) MD15 Hospital das Forças Armadas

91) MD18 Comando do Exército

92) MD4 Gabinete do Ministro

93) MD6 Secretaria de Controle Interno

94) MD7 Secretaria-Geral

95) MD8 Centro Gestor e Operacional do Sistema de Proteção da Amazônia

96) MD9 Secretaria de Orçamento e Organização Institucional

97) MD99 Outros

98) MDr1 Agência Nacional de Águas

99) MDr10 Consultoria Jurídica

100) MDr11 Gabinete

101) MDr12 Secretaria Executiva

102) MDr13 Secretaria Nacional de Desenvolvimento Regional e Urbano

103) MDr14 Secretaria Nacional de Habitação

104) MDr15 Secretaria Nacional de Mobilidade e Serviços Urbanos

105) MDr16 Secretaria Nacional de Proteção e Defesa Civil

106) MDr17 Secretaria Nacional de Saneamento

107) MDr18 Secretaria Nacional de Segurança Hídrica

108) MDr4 Departamento Nacional de Obras Contra as Secas

109) MDr7 Superintendência do Desenvolvimento da Amazônia

110) MDr8 Superintendência do Desenvolvimento do Nordeste

111) MDr99 Outros

112) ME12 Fundação Escola Nacional de Administração Pública 
113) ME13 Fundação Instituto Brasileiro de Geografia e Estatística

114) ME18 Instituto Nacional do Seguro Social

115) ME19 Instituto de Pesquisa Econômica Aplicada

116) ME21 Superintendência Nacional de Previdência Complementar

117) ME24 Assessoria Especial de Assuntos Estratégicos

118) ME28 Secretaria Executiva

119) ME29 Procuradoria-Geral da Fazenda Nacional

120) ME30 Secretaria Especial da Receita Federal do Brasil

121) ME31 Secretaria Especial de Comércio Exterior e Assuntos Internacionais

122) ME32 Secretaria Especial de Desburocratização, Gestão e Governo Digital

123) ME33 Secretaria Especial de Desestatização e Desinvestimento

124) ME34 Secretaria Especial de Fazenda

125) ME35 Secretaria Especial de Previdência e Trabalho

126) ME36 Secretaria Especial de Produtividade, Emprego e Competitividade

127) ME37 Unidades colegiadas

128) ME99 Outros

129) MEd10 Secretaria Executiva

130) MEd14 Secretaria de Educação Básica

131) MEd15 Secretaria de Educação Profissional e Tecnológica

132) MEd16 Secretaria de Educação Superior

133) MEd17 Secretaria de Modalidades Especializadas de Educação

134) MEd18 Secretaria de Regulação e Supervisão da Educação Superior

135) MEd19 Unidades colegiadas

136) MEd4 Fundo Nacional de Desenvolvimento da Educação

137) MEd9 Gabinete do Ministro

138) MEd99 Outros

139) MI12 Departamento Nacional de Infraestrutura de Transportes

140) MI17 Assessoria Especial de Comunicação 
141) MI2 Agência Nacional de Transportes Aquaviários

142) MI20 Corregedoria

143) MI21 Gabinete do Ministro

144) MI22 Secretaria Executiva

145) MI23 Secretaria Nacional de Aviação Civil

146) MI24 Secretaria Nacional de Portos e Transportes Aquaviários

147) MI25 Secretaria Nacional de Transportes Terrestres

148) MI26 Secretaria de Fomento, Planejamento e Parcerias

149) MI28 Unidades colegiadas

150) MI3 Agência Nacional de Transportes Terrestres

151) MI99 Outros

152) MJ1 Conselho Administrativo de Defesa Econômica

153) MJ10 Arquivo Nacional

154) MJ11 Departamento Penitenciário Nacional

155) MJ12 Polícia Federal

156) MJ14 Secretaria Nacional de Justiça

157) MJ15 Secretaria Nacional de Políticas sobre Drogas

158) MJ16 Secretaria Nacional de Segurança Pública

159) MJ17 Secretaria Nacional do Consumidor

160) MJ18 Secretaria de Operaçóes Integradas

161) MJ2 Fundação Nacional do Índio

162) MJ7 Consultoria Jurídica

163) MJ8 Gabinete do Ministro

164) MJ9 Secretaria Executiva

165) MJ99 Outros

166) MM1 Assessoria Especial de Assuntos Internacionais

167) MM10 Secretaria Nacional de Políticas de Promoção da Igualdade Racial

168) MM11 Secretaria Nacional de Políticas para as Mulheres 
169) MM12 Secretaria Nacional de Promoção e Defesa dos Direitos da Pessoa Idosa 170) MM13 Secretaria Nacional de Proteção Global

171) MM16 Unidades colegiadas

172) MM6 Ouvidoria Nacional de Direitos Humanos

173) MM7 Secretaria Executiva

174) MM9 Secretaria Nacional da Juventude

175) MM99 Outros

176) MMA1 Instituto Brasileiro do Meio Ambiente e dos Recursos Naturais Renováveis

177) MMA10 Secretaria de Florestas e Desenvolvimento Sustentável

178) MMA11 Secretaria de Qualidade Ambiental

179) MMA12 Secretaria de Relaçôes Internacionais

180) MMA2 Instituto Chico Mendes de Conservação da Biodiversidade

181) MMA4 Assessoria Especial de Controle Interno

182) MMA5 Consultoria Jurídica

183) MMA6 Gabinete

184) MMA7 Secretaria Executiva

185) MMA8 Secretaria de Biodiversidade

186) MMA9 Secretaria de Ecoturismo

187) MMA99 Outros

188) MMe14 Assessoria Especial de Relações Internacionais

189) MMe15 Consultoria Jurídica

190) MMe16 Gabinete do Ministro

191) MMe17 Secretaria Executiva

192) MMe18 Secretaria de Energia Elétrica

193) MMe19 Secretaria de Geologia, Mineração e Transformação Mineral

194) MMe2 Agência Nacional de Mineração

195) MMe20 Secretaria de Petróleo, Gás Natural e Biocombustíveis

196) MMe21 Secretaria de Planejamento e Desenvolvimento Energético 
197) MMe99 Outros

198) MRE13 Escritório de Representação no Estado de Minas Gerais

199) MRE15 Escritório de Representação no Estado de São Paulo

200) MRE20 Unidades colegiadas

201) MRE3 Assessoria de Relações Federativas e com o Congresso Nacional

202) MRE4 Consultoria Jurídica

203) MRE5 Gabinete do Ministro

204) MRE6 Instituto Rio Branco

205) MRE9 Secretaria-Geral das Relaçôes Exteriores

206) MRE99 Outros

207) MS10 Gabinete do Ministro

208) MS11 Secretaria Executiva

209) MS12 Secretaria Especial de Saúde Indígena

210) MS13 Secretaria de Atenção Especializada à Saúde

211) MS14 Secretaria de Atenção Primária à Saúde

212) MS15 Secretaria de Ciência, Tecnologia, Inovação e Insumos Est. em Saúde

213) MS17 Secretaria de Gestão do Trabalho e da Educação na Saúde

214) MS4 Fundação Nacional de Saúde

215) MS5 Fundação Oswaldo Cruz

216) MS8 Departamento Nacional de Auditoria do Sistema Único de Saúde

217) MS9 Diretoria de Integridade

218) MS99 Outros

219) MT3 Assessoria Especial de Relaçóes Internacionais

220) MT4 Consultoria Jurídica

221) MT6 Secretaria Executiva

222) MT7 Secretaria Nacional de Desenvolvimento e Competitividade do Turismo

223) MT8 Secretaria Nacional de Estruturação do Turismo

224) MT9 Secretaria Nacional de Integração Interinstitucional 
225) MT99 Outros

226) MD16 Comando da Aeronáutica

227) MD17 Comando da Marinha

999 Sem resposta

-888 Não se aplica

QA16 - EM QUE UNIDADE DA FEDERAÇÃO VOCÊ TRABALHA ATUALMENTE?

1) Distrito Federal (DF)

2) Rio de Janeiro (RJ)

3) Acre (AC)

4) Alagoas (AL)

6) Amazonas (AM)

7) Bahia (BA)

8) Ceará (CE)

9) Espírito Santo (ES)

10) Goiás (GO)

11) Maranhão (MA)

12) Mato Grosso (MT)

13) Mato Grosso do Sul (MS)

14) Minas Gerais (MG)

15) Pará (PA)

16) Paraíba (PB)

17) Paraná (PR)

18) Pernambuco (PE)

19) Piauí (PI)

20) Rio Grande do Norte (RN)

21) Rio Grande do Sul (RS)

22) Rondônia (RO)

23) Roraima (RR) 
24) Santa Catarina (SC)

25) São Paulo (SP)

26) Sergipe (SE)

27) Tocantins (TO)

999 Sem resposta

Seção B - Política pública

QB1 - EM QUAL PROGRAMA DO PLANO PLURIANUAL 2016-2019 A POLÍTICA PÚBLICA NA QUAL VOCÊ TRABALHA SE INSERE?

1) Social e segurança pública

2) Infraestrutura

3) Desenvolvimento produtivo e ambiental

4) Temas especiais

999 Sem resposta

QB1PPA - ESPECIFIQUE:

1) A1 Consolidação do Sistema Único de Assistência Social (Suas)

2) A10 Previdência Social

3) A11 Promoção da Igualdade Racial e Superação do Racismo

4) A12 Promoçáo dos Direitos da Juventude

5) A13 Promoção do Trabalho Decente e Economia Solidária

6) A15 Promoção e Defesa dos Direitos Humanos

7) A16 Promoção, Proteção e Defesa dos Direitos Humanos de Crianças e Adolesc.

8) A17 Proteção e Promoção dos Direitos dos Povos Indígenas

9) A18 Redução do Impacto Social do Álcool e Outras Drogas

10) A19 Reforma Agrária e Governança Fundiária

11) A2 Cultura: Dimensão Essencial do Desenvolvimento

12) A20 Segurança Alimentar e Nutricional

13) A3 Educação de Qualidade para Todos

14) A4 Esporte, Cidadania e Desenvolvimento 
15) A5 Fortalecimento do Sistema Único de Saúde (SUS)

16) A6 Fortalecimento e Dinamização da Agricultura Familiar

17) A7 Inclusão Social Por Meio do Bolsa Família, do Cadastro Único

18) A8 Justiça, Cidadania e Segurança Pública

19) A9 Políticas para as Mulheres: Promoção da Igualdade e Enfrentamento à Violênc.

20) B1 Aviação Civil

21) B10 Planejamento Urbano

22) B11 Saneamento Básico

23) B12 Transporte Aquaviário

24) B13 Transporte Terrestre

25) B2 Combustíveis

26) B3 Comunicações para o Desenvolvimento, a Inclusão e a Democracia

27) B4 Energia Elétrica

28) B5 Geologia, Mineração e Transformação Mineral

29) B6 Gestão de Riscos e de Desastres

30) B7 Mobilidade Urbana e Trânsito

31) B8 Moradia Digna

32) B9 Petróleo e Gás

33) C1 Agropecuária Sustentável

34) C10 Pesquisa e Inovações para a Agropecuária

35) C11 Qualidade Ambiental

36) C12 Recursos Hídricos

37) C13 Simplificação da Vida da Empresa e do Cidadão

38) C2 Ciência, Tecnologia e Inovação

39) C3 Comércio Exterior

40) C4 Conservação e Uso Sustentável da Biodiversidade

41) C5 Defesa Agropecuária 
42) C6 Desenvolvimento da Indústria, Comércio e Serviços

43) C7 Desenvolvimento e Promoção do Turismo

44) C8 Mudança do Clima

45) C9 Pesca e Aquicultura

46) D1 Defesa Nacional

47) D2 Democracia e Aperfeiçoamento da Gestão Pública

48) D3 Desenvolvimento Regional e Territorial

49) D4 Gestão da Política Econômica, Garantia da Estabilidade do Sistema Financeiro

51) D6 Oceanos, Zona Costeira e Antártica

52) D7 Política Espacial

53) D8 Política Externa

54) D9 Política Nuclear

999 Sem resposta

-888 Não se aplica

QB2 - HÁ QUANTO TEMPO VOCÊ TRABALHA NESTA POLÍTICA PÚBLICA?

1) Até 6 meses

2) Entre 6 meses a 1 ano

3) Entre 1 a 5 anos

4) Entre 5 a 10 anos

5) Mais de 10 anos

999 Sem resposta

-888 Não se aplica

Seção C - Função na política pública

QCOA - NOS ÚLTIMOS 12 MESES, COM QUE FREQUÊNCIA VOCÊ EXECUTOU AS ATIVIDADES ABAIXO RELACIONADAS À POLÍTICA PÚBLICA NA QUAL VOCÊ TRABALHA? (CASO TENHA MUDADO DE ÓRGÃO OU FUNÇÃO NESSE PERÍODO, CONSIDERE A SUA SITUAÇÃO ATUAL PARA RESPONDER).

QC1 - ELABORAR RELATÓRIOS, PARECERES, NOTAS TÉCNICAS E OUTRAS INFORMAÇÕES PARA SUBSIDIAR A TOMADA DE DECISÕES 
1) Nunca

2) Raramente

3) Eventualmente

4) Frequentemente

5) Sempre

999 Sem resposta

QC2 - COLETAR E ANALISAR DADOS E INFORMAÇÕES RELACIONADAS À POLÍTICA PÚBLICA

1) Nunca

2) Raramente

3) Eventualmente

4) Frequentemente

5) Sempre

999 Sem resposta

QC3 - CONTRATAR E VALIDAR ESTUDOS DE AVALIAÇÃO DE PROCESSOS, RESULTADOS

E IMPACTOS DA POLÍTICA PÚBLICA

1) Nunca

2) Raramente

3) Eventualmente

4) Frequentemente

5) Sempre

999 Sem resposta

QC4 - ELABORAR TEXTOS NORMATIVOS (EX. PROJETOS DE LEI, DECRETOS, PORTARIAS, ETC.)

1) Nunca

2) Raramente

3) Eventualmente

4) Frequentemente

5) Sempre

999 Sem resposta 
QC5 - FISCALIZAR O CUMPRIMENTO DAS NORMAS E REGULAMENTOS DA POLÍTICA PÚBLICA

1) Nunca

2) Raramente

3) Eventualmente

4) Frequentemente

5) Sempre

999 Sem resposta

QC6 - CAPTAR E NEGOCIAR RECURSOS FINANCEIROS PARA VIABILIZAR AÇÕES, PROJETOS E PROGRAMAS DA POLÍTICA PÚBLICA

1) Nunca

2) Raramente

3) Eventualmente

4) Frequentemente

5) Sempre

999 Sem resposta

QC7 - ELABORAR, NEGOCIAR, GERIR E FISCALIZAR CONTRATOS, CONVÊNIOS, TERMOS DE FOMENTO, TERMOS DE COLABORAÇÃO E OUTROS INSTRUMENTOS

1) Nunca

2) Raramente

3) Eventualmente

4) Frequentemente

5) Sempre

999 Sem resposta

QC8 - COORDENAR EQUIPE

1) Nunca

2) Raramente

3) Eventualmente

4) Frequentemente

5) Sempre

999 Sem resposta 
QC9 - REPRESENTAR SEU ÓRGÃO, NEGOCIAR E PACTUAR AÇÕES E POLÍTICAS JUNTO A OUTROS ENTES GOVERNAMENTAIS (EX. OUTROS MINISTÉRIOS, ESTADOS E MUNCÍPIOS, ETC.)

1) Nunca

2) Raramente

3) Eventualmente

4) Frequentemente

5) Sempre

999 Sem resposta

QC10 - ATENDER DEMANDAS DOS ÓRGÃOS DE CONTROLE

1) Nunca

2) Raramente

3) Eventualmente

4) Frequentemente

5) Sempre

999 Sem resposta

QC11 - CONSULTAR E ATENDER A GRUPOS INTERESSADOS DA SOCIEDADE SOBRE QUESTÕES QUE ENVOLVAM A POLÍTICA PÚBLICA

1) Nunca

2) Raramente

3) Eventualmente

4) Frequentemente

5) Sempre

999 Sem resposta

QC12 - REALIZAR ASSESSORAMENTO DE DIRIGENTES

1) Nunca

2) Raramente

3) Eventualmente

4) Frequentemente

5) Sempre

999 Sem resposta 
QC13 - REALIZAR ATIVIDADES ADMINISTRATIVAS, TAIS COMO AGENDAMENTO DE REUNIÕES, TRAMITAÇÃO DE PROCESSOS, COMPRA DE PASSAGENS, ELABORAÇÃO DE OFÍCIOS E MEMORANDOS

1) Nunca

2) Raramente

3) Eventualmente

4) Frequentemente

5) Sempre

999 Sem resposta

QC14 - ORGANIZAR EVENTOS

1) Nunca

2) Raramente

3) Eventualmente

4) Frequentemente

5) Sempre

999 Sem resposta

QC15 - NOS ÚLTIMOS 12 MESES, COMO PARTE DAS SUAS ATIVIDADES PROFISSIONAIS, VOCÊ LEU DOCUMENTOS E PUBLICAÇÕES EM LÍNGUA ESTRANGEIRA?

0 Não

$1 \mathrm{Sim}$

999 Sem resposta

QC15B - EM QUAL (IS) IDIOMA (S)? (SELECIONE TODAS AS OPÇÕES QUE SE APLIQUEM)

QC15B_1 - INGLÊS

0 Não selecionado

1 selecionado

-888 Não se aplica

QC15B_2 - ESPANHOL

0 Não selecionado

1 Selecionado 
-888 Não se aplica

QC15B_3 - FRANCÊS

0 Não selecionado

1 Selecionado

-888 Não se aplica

QC15B_OUTROS - OUTROS

0 Não selecionado

1 Selecionado

-888 Não se aplica

QC16 - PENSE NO QUE SERIA UMA SEMANA TÍPICA DE TRABALHO PARA VOCÊ. QUANTAS HORAS VOCÊ TRABALHA POR SEMANA?

Entrada numérica: 0 A 99

999 Sem resposta

QC16A - TENDO EM VISTA SUA SEMANA TÍPICA DE TRABALHO, QUANTAS HORAS VOCÊ OCUPA COM REUNIÕES?

Entrada numérica: 0 A 99

999 Sem resposta

QC16B - TENDO EM VISTA SUA SEMANA TÍPICA DE TRABALHO, QUANTAS HORAS VOCÊ OCUPA NA PROCURA E LEITURA DE ESTUDOS E PESQUISAS CIENTÍFICAS PARA O SEU TRABALHO?

Entrada numérica: 0 A 99

999 Sem resposta

QCOB - NOS ÚLTIMOS 12 MESES, COM QUE FREQUÊNCIA VOCÊ TEM INTERAGIDO COM OS ATORES/ORGANIZAÇÕES ABAIXO PARA EXECUTAR O SEU TRABALHO? (CASO TENHA MUDADO DE ÓRGÃO OU FUNÇÃO NESSE PERÍODO, CONSIDERE A SUA SITUAÇÃO ATUAL PARA RESPONDER).

QC17 - OUTRAS ÁREAS DO MEU MINISTÉRIO OU ENTIDADE

1) Nunca

2) Raramente

3) Eventualmente

4) Frequentemente 
5) Sempre

999 Sem resposta

QC18 - OUTROS MINISTÉRIOS OU ENTIDADES DO GOVERNO FEDERAL

1) Nunca

2) Raramente

3) Eventualmente

4) Frequentemente

5) Sempre

999 Sem resposta

QC19 - GOVERNOS ESTADUAIS E/OU MUNICIPAIS

1) Nunca

2) Raramente

3) Eventualmente

4) Frequentemente

5) Sempre

999 Sem resposta

QC2O - REPRESENTANTES DO PODER LEGISLATIVO

1) Nunca

2) Raramente

3) Eventualmente

4) Frequentemente

5) Sempre

999 Sem resposta

QC21 - REPRESENTANTES DO PODER JUDICIÁRIO E MINISTÉRIO PÚBLICO

1) Nunca

2) Raramente

3) Eventualmente

4) Frequentemente 
5) Sempre

999 Sem resposta

QC22 - ÓRGÃO DE CONTROLE (CGU, TCU)

1) Nunca

2) Raramente

3) Eventualmente

4) Frequentemente

5) Sempre

999 Sem resposta

QC23 - ORGANIZAÇÕES DA SOCIEDADE CIVIL (ONGS, ASSOCIAÇÕES, ETC.) E/OU INSTÂNCIAS PARTICIPATIVAS (CONSELHO DE POLÍTICAS PÚBLICAS, CONFERÊNCIAS, ETC.)

1) Nunca

2) Raramente

3) Eventualmente

4) Frequentemente

5) Sempre

999 Sem resposta

QC24 - SETOR PRIVADO E/OU EMPRESAS PÚBLICAS OU DE ECONOMIA MISTA

1) Nunca

2) Raramente

3) Eventualmente

4) Frequentemente

5) Sempre

999 Sem resposta

QC25 - ENTIDADES DO SISTEMA SINDICAL (PATRONAL OU DE TRABALHADORES)

1) Nunca

2) Raramente

3) Eventualmente

4) Frequentemente 
5) Sempre

999 Sem resposta

QC26 - MÍDIA E IMPRENSA

1) Nunca

2) Raramente

3) Eventualmente

4) Frequentemente

5) Sempre

999 Sem resposta

QC27 - UNIVERSIDADES, INSTITUTOS DE PESQUISA, PROFESSORES UNIVERSITÁRIOS E PESQUISADORES INDIVIDUAIS

1) Nunca

2) Raramente

3) Eventualmente

4) Frequentemente

5) Sempre

999 Sem resposta

QC28 - ORGANISMOS INTERNACIONAIS (EX. ONU, BANCO MUNDIAL) OU GOVERNOS DE OUTROS PAÍSES

1) Nunca

2) Raramente

3) Eventualmente

4) Frequentemente

5) Sempre

999 Sem resposta

QC29 - BENEFICIÁRIOS DE PROGRAMAS E POLÍTICAS

1) Nunca

2) Raramente 
3) Eventualmente

4) Frequentemente

5) Sempre

999 Sem resposta

SEÇÃO D - FONTES DE INFORMAÇÃO

QDOA - NOS ÚLTIMOS 12 MESES, COM QUE FREQUÊNCIA VOCÊ UTILIZOU OS TIPOS DE INFORMAÇÃO LISTADOS ABAIXO PARA O SEU TRABALHO? (CASO TENHA MUDADO DE ÓRGÃO OU FUNÇÃO NESSE PERÍODO, CONSIDERE A SUA SITUAÇÃO ATUAL PARA RESPONDER).

QD1 - LEIS E NORMAS

1) Nunca

2) Raramente

3) Eventualmente

4) Frequentemente

5) Sempre

99 Não sei

QD2 - NOTAS TÉCNICAS PRODUZIDAS POR ÓRGÃOS DA ADMINISTRAÇÃO PÚBLICA FEDERAL

1) Nunca

2) Raramente

3) Eventualmente

4) Frequentemente

5) Sempre

99 Não sei

QD3 - PARECERES LEGAIS E DECISÕES JUDICIAIS

1) Nunca

2) Raramente

3) Eventualmente

4) Frequentemente

5) Sempre 
99 Não sei

QD4 - RECOMENDAÇÕES DE ÓRGÃOS DE CONTROLE

1) Nunca

2) Raramente

3) Eventualmente

4) Frequentemente

5) Sempre

99 Não sei

QD5 - BOAS PRÁTICAS E INICIATIVAS PRODUZIDAS PELOS ESTADOS E MUNICÍPIOS

1) Nunca

2) Raramente

3) Eventualmente

4) Frequentemente

5) Sempre

99 Não sei

QD6 - SISTEMAS INFORMACIONAIS E BASES DE DADOS GOVERNAMENTAIS (EX. SIAFI, CADASTRO ÚNICO, DADOS DO IBGE, ETC.)"

1) Nunca

2) Raramente

3) Eventualmente

4) Frequentemente

5) Sempre

99 Não sei

QD7 - ARTIGOS, CAPÍTULOS OU LIVROS PRODUZIDOS POR PESQUISADORES

1) Nunca

2) Raramente

3) Eventualmente

4) Frequentemente 
5) Sempre

99 Não sei

QD8 - RELATÓRIOS DE PESQUISA CIENTÍFICA (EX. PRODUTOS DE CONSULTORIA DE PESQUISA, TEXTOS DE DISCUSSÃO DO IPEA, ETC.)

1) Nunca

2) Raramente

3) Eventualmente

4) Frequentemente

5) Sempre

99 Não sei

QD9 - RECOMENDAÇÕES DE INSTÂNCIAS PARTICIPATIVAS (EX. CONSELHO DE POLÍTICAS PÚBLICAS, CONFERÊNCIAS, ETC.)

1) Nunca

2) Raramente

3) Eventualmente

4) Frequentemente

5) Sempre

99 Não sei

QD10 - EXPERIÊNCIA E OPINIÕES DE BENEFICIÁRIO DA POLÍTICA PÚBLICA OU COMENTÁRIOS E SUGESTÕES DE OUVIDORIA

1) Nunca

2) Raramente

3) Eventualmente

4) Frequentemente

5) Sempre

99 Não sei

QD11 - INFORMAÇÕES GERADAS POR GRUPOS DE INTERESSE (EX. SINDICATOS, EMPRESAS, MOVIMENTOS SOCIAIS, ONGS, ETC.)

1) Nunca

2) Raramente 
3) Eventualmente

4) Frequentemente

5) Sempre

99 Não sei

QD12 - OPINIÕES E RECOMENDAÇÕES DE ORGANISMOS INTERNACIONAIS OU BOAS PRÁTICAS PRODUZIDAS POR GOVERNOS DE OUTROS PAÍSES

1) Nunca

2) Raramente

3) Eventualmente

4) Frequentemente

5) Sempre

99 Não sei

QD13 - MATÉRIA JORNALÍSTICA

1) Nunca

2) Raramente

3) Eventualmente

4) Frequentemente

5) Sempre

99 Não sei

QD14 - EXPERIÊNCIA PESSOAL

1) Nunca

2) Raramente

3) Eventualmente

4) Frequentemente

5) Sempre

99 Não sei 
QD15 - CONSULTA A COLEGAS DE TRABALHO DO PRÓPRIO ÓRGÃO OU DE OUTROS ÓRGÃOS DA ADMINISTRAÇÃO FEDERAL

1) Nunca

2) Raramente

3) Eventualmente

4) Frequentemente

5) Sempre

99 Não sei

QDOB - CONSIDERANDO OS ÚLTIMOS 12 MESES, COMO PARTE DO SEU TRABALHO, COM QUE FREQUÊNCIA VOCÊ RECORRE A: (CASO TENHA MUDADO DE ÓRGÃO OU FUNÇÃO NESSE PERÍODO, CONSIDERE A SUA SITUAÇÃO ATUAL PARA RESPONDER).

QD17 - ESTUDOS BASEADOS EM ANÁLISE DE CORRELAÇÃO, TÉCNICAS ESTATÍSTICAS MULTIVARIADAS OU PESQUISAS DE OPINIÃO (SURVEY)

1) Nunca

2) Raramente

3) Eventualmente

4) Frequentemente

5) Sempre

99 Não sei

QD18 - ESTUDOS BASEADOS EM MÉTODOS QUALITATIVOS, TAIS COMO GRUPOS FOCAIS, ETNOGRAFIA, ENTREVISTAS, ESTUDOS DE CASO, ETC.

1) Nunca

2) Raramente

3) Eventualmente

4) Frequentemente

5) Sempre

99 Não sei

QD19 - ESTUDOS BASEADOS EM MÉTODOS MISTOS (QUANTI-QUALI)

1) Nunca

2) Raramente 
3) Eventualmente

4) Frequentemente

5) Sempre

99 Não sei

QD20 - ESTUDOS DE REVISÃO DE LITERATURA E EMINENTEMENTE TEÓRICOS

1) Nunca

2) Raramente

3) Eventualmente

4) Frequentemente

5) Sempre

99 Não sei

QDOC - COMO VOCÊ TOMA CONHECIMENTO DE RESULTADOS DE PESQUISAS E ESTUDOS CIENTÍFICOS RELEVANTES PARA O SEU TRABALHO? (SELECIONE TODAS AS OPÇÕES QUE SE APLICAM).

QD21 - IMPRENSA (EX. FOLHA DE S. PAULO, NEXO JORNAL, ESTADÃO, VALOR ECONÔMICO, ETC.) 0 Não selecionado

\section{Selecionado}

-88 Não quis responder

QD22 - PORTAL DE PERIÓDICOS OU BANCO DE TESES E DISSERTAÇÕES (EX. SCIELO, GOOGLE SCHOLAR, PROQUEST, ETC.)

0 Não selecionado

1 Selecionado

-88 Não quis responder

QD23 - GOOGLE OU OUTRAS FERRAMENTAS DE BUSCA NA INTERNET (EX. BING, YAHOO, ASK. COM)

0 Não selecionado

1 Selecionado

-88 Não quis responder 
QD24 - EM EVENTOS, SEMINÁRIOS OU CONGRESSOS CIENTÍFICOS

0 Não selecionado

1 Selecionado

-88 Não quis responder

QD25 - POR CITAÇÕES EM ESTUDOS ACADÊMICOS

0 Não selecionado

1 Selecionado

-88 Não quis responder

QD26 - POR BUSCA PRESENCIAL OU EM SITES DE BIBLIOTECAS

0 Não selecionado

1 Selecionado

-88 Não quis responder

QD27 - POR BUSCA EM SITES DE INSTITUIÇÕES DE PESQUISA (EX. IPEA, ENAP, FIOCRUZ, UNB, ETC.)

0 Não selecionado

1 Selecionado

-88 Não quis responder

QD28 - REDES SOCIAIS (EX. FACEBOOK, TWITTER, WHATSAPP, ETC.)

0 Não selecionado

1 Selecionado

-88 Não quis responder

QD29 - PLATAFORMAS DE COMPARTILHAMENTO DE ÁUDIO E VÍdEO (EX. PODCAST, YOUTUBE)

0 Náo selecionado

1 Selecionado

-88 Não quis responder

QD30 - INDICAÇÃO DE CONHECIDOS

0 Não selecionado

1 Selecionado

-88 Não quis responder 
QD31 - SITES DE ORGANISMOS INTERNACIONAIS (EX. ONU, OCDE, BANCO MUNDIAL, ETC.)

0 Não selecionado

\section{Selecionado}

-88 Não quis responder

DOD - AVALIE A CONTRIBUIÇÃO DO USO DE PESQUISAS E ESTUDOS CIENTÍFICOS NO SEU CONTEXTO DE TRABALHO. INDIQUE O GRAU DE CONCORDÂNCIA COM AS AFIRMAÇÕES ABAIXO:

QD33 - O USO DE PESQUISAS E ESTUDOS CIENTÍFICOS LEVA A AÇÕES CONCRETAS NO MEU TRABALHO

1) Discordo totalmente

2) Discordo

3) Indiferente

4) Concordo

5) Concordo totalmente

99 Não sei

QD34 - O USO DE PESQUISAS E ESTUDOS CIENTÍFICOS SERVE PARA ESCLARECER SITUAÇÕES E PROBLEMAS NO MEU TRABALHO

1) Discordo totalmente

2) Discordo

3) Indiferente

4) Concordo

5) Concordo totalmente

99 Não sei

QD35 - O USO DE PESQUISAS E ESTUDOS CIENTÍFICOS SERVE PARA CONFIRMAR ESCOLHAS E LEGITIMAR DECISÕES JÁ TOMADAS

1) Discordo totalmente

2) Discordo

3) Indiferente

4) Concordo

5) Concordo totalmente

99 Não sei 
QDOE - INDIQUE QUAL O NÍVEL DE RELEVÂNCIA DOS FATORES A SEGUIR NA SUA DECISÃO DE UTILIZAR INFORMAÇÕES PROVENIENTES DE PESQUISAS E ESTUDOS CIENTÍFICOS:

QD36 - FACILIDADE DE COMPREENSÃO DA PESQUISA OU ESTUDO CIENTÍFICO

1) Irrelevante

2) Pouco relevante

3) Relevante

4) Muito relevante

5) Decisivo

99 Não sei

QD37 - EXISTÊNCIA DE CONCLUSÕES E RECOMENDAÇÕES DE NATUREZA OPERACIONAL ESPECÍFICA

1) Irrelevante

2) Pouco relevante

3) Relevante

4) Muito relevante

5) Decisivo

99 Não sei

QD38 - CREDIBILIDADE E PRESTÍGIO DA FONTE

1) Irrelevante

2) Pouco relevante

3) Relevante

4) Muito relevante

5) Decisivo

99 Não sei

QD39 - PERTINÊNCIA E APLICABILIDADE DA INFORMAÇÃO EM RELAÇÃO AOS OBJETIVOS QUE EU POSSUO EM MEU TRABALHO

1) Irrelevante

2) Pouco relevante

3) Relevante

4) Muito relevante 
5) Decisivo

99 Não sei

QD40 - TEMPESTIVIDADE (A PESQUISA CHEGA A MIM NO TEMPO ADEQUADO PARA SER UTILIZADA)

1) Irrelevante

2) Pouco relevante

3) Relevante

4) Muito relevante

5) Decisivo

99 Não sei

QD41 - ATRATIVIDADE (LEITURA FÁCIL; GRÁFICOS; CORES; ETC.)

1) Irrelevante

2) Pouco relevante

3) Relevante

4) Muito relevante

5) Decisivo

99 Não sei

QD42 - TAMANHO (NÚMERO DE PÁGINAS)

1) Irrelevante

2) Pouco relevante

3) Relevante

4) Muito relevante

5) Decisivo

99 Não sei

QDOH - VAMOS AGORA TRATAR DA SUA ROTINA DE TRABALHO E DO FUNCIONAMENTO DA SUA ORGANIZAÇÃO. POR FAVOR, INDIQUE SUA OPINIÃO SOBRE AS SENTENÇAS A SEGUIR:

QD44 - DURANTE MINHA JORNADA DE TRABALHO, HÁ TEMPO SUFICIENTE PARA LEITURA DE PESQUISAS E ESTUDOS CIENTÍFICOS RELEVANTES

1) Nunca 
2) Raramente

3) Eventualmente

4) Frequentemente

5) Sempre

99 Não sei

QD45 - NO MEU TRABALHO, QUANDO PRECISO TOMAR UMA DECISÃO, PREFIRO RECORRER A PESQUISAS E ESTUDOS CIENTÍFICOS DO QUE A OUTRAS FONTES DE INFORMAÇÃO

1) Nunca

2) Raramente

3) Eventualmente

4) Frequentemente

5) Sempre

99 Não sei

QD46 - NA MINHA ROTINA DE TRABALHO, EU FAÇO PESSOALMENTE ESFORÇOS PARA ENTRAR EM CONTATO COM PESQUISADORES E ACADÊMICOS

1) Nunca

2) Raramente

3) Eventualmente

4) Frequentemente

5) Sempre

99 Não sei

QD47 - ASSESSORES E SERVIDORES DA MINHA ORGANIZAÇÃO SÃO ENCORAJADOS PELOS DIRIGENTES A UTILIZAR RESULTADOS DE PESQUISAS E ESTUDOS CIENTÍFICOS

1) Nunca

2) Raramente

3) Eventualmente

4) Frequentemente

5) Sempre

99 Não sei 
QD48 - MINHA ORGANIZAÇÃO OFERECE OPORTUNIDADES PARA CONSTRUIR RELACIONAMENTOS COM PESQUISADORES DE UNIVERSIDADES E INSTITUTOS DE PESQUISA

1) Nunca

2) Raramente

3) Eventualmente

4) Frequentemente

5) Sempre

99 Não sei

QD49 - MINHA ORGANIZAÇÃO DISPÕE DE MEIOS E RECURSOS SUFICIENTES PARA OBTER INFORMAÇÕES PRODUZIDAS POR PESQUISAS E ESTUDOS CIENTÍFICOS

1) Nunca

2) Raramente

3) Eventualmente

4) Frequentemente

5) Sempre

99 Não sei

QD50 - EM RELAÇÃO À ESTRUTURA DO SEU MINISTÉRIO/ÓRGÃO, HÁ UMA UNIDADE ORGANIZACIONAL (ASSESSORIA, COORDENAÇÃO, DEPARTAMENTO OU SECRETARIA) ESPECIALIZADA NA UTILIZAÇÃO DE PESQUISAS E ESTUDOS CIENTÍFICOS?

0 Não

$1 \mathrm{Sim}$

99 Não sei

QDOI - QUAIS DAS ATRIBUIÇÕES ABAIXO SÃO EXECUTADAS POR ESSA UNIDADE ORGANIZACIONAL ESPECIALIZADA? (SELECIONE TODAS AS OPÇÕES QUE SE APLICAM).

QD60 - PROSPECTAR PESQUISAS E ESTUDOS CIENTÍFICOS REALIZADOS

0 Não selecionado

1 Selecionado

99 Não sabe

-888 Não se aplica 
QD61 - CONTRATAR PESQUISAS E ESTUDOS CIENTÍFICOS

0 Não selecionado

1 Selecionado

99 Não sabe

-888 Não se aplica

QD62 - TRADUZIR OS RESULTADOS DE PESQUISA E ESTUdOS CIENTÍFICOS EM RECOMENDAÇÕES

0 Não selecionado

1 Selecionado

99 Não sabe

-888 Não se aplica

QD63 - DISSEMINAR OS RESULTADOS PRODUZIDOS PELAS PESQUISAS E ESTUDOS CIENTÍFICOS

0 Não selecionado

\section{Selecionado}

99 Não sabe

-888 Não se aplica

QD64 - PRODUÇÃO DE PESQUISAS E ESTUDOS CIENTíFICOS

0 Não selecionado

\section{Selecionado}

99 Não sabe

-888 Não se aplica

SEÇÃO E - CONHECIMENTOS, HABILIDADES E VALORES

QEOA - SE VOCÊ FOR SOLICITADO A REALIZAR AS TAREFAS ABAIXO, QUAL O GRAU DE FACILIDADE QUE VOCÊ TERÁ EM REALIZÁ-LAS? (RESPONDA EM UMA ESCALA DE 1 A 10 , NA QUAL O PONTO 1 REPRESENTA "MUITO DIFÍCIL" E O PONTO 10 REPRESENTA "MUITA FACILIDADE").

QE1 - IDENTIFICAR, COLETAR E ANALISAR DADOS E INFORMAÇÕES RELACIONADOS À POLÍTICA PÚBLICA

1) Muito difícil

2) 2 
3) 3

4) 4

5) 5

6) 6

7) 7

8) 8

9) 9

10) Muito fácil

999 Sem resposta

QE2 - INTERPRETAR RESULTADOS DE ANÁLISES ESTATÍSTICAS

1) Muito difícil

2) 2

3) 3

4) 4

5) 5

6) 6

7) 7

8) 8

9) 9

10) Muito fácil

999 Sem resposta

QE3 - DEFINIR INDICADORES E METODOLOGIAS PARA AVALIAÇÃO E MONITORAMENTO DA POLÍTICA PÚBLICA

1) Muito difícil

2) 2

3) 3

4) 4

5) 5 
6) 6

7) 7

8) 8

9) 9

10) Muito fácil

999 Sem resposta

QE4 - UTILIZAR NOVAS FERRAMENTAS E TECNOLOGIAS DE PROCESSAMENTO DE DADOS E DE ANÁLISE ESTATÍSTICA (PROGRAMAÇÃO EM R, STATA, PYTHON OU JAVA ETC.)

1) Muito difícil

2) 2

3) 3

4) 4

5) 5

6) 6

7) 7

8) 8

9) 9

10) Muito fácil

999 Sem resposta

QE5 - UTILIZAR NOVAS FERRAMENTAS E TECNOLOGIAS DE INFORMAÇÃO E COMUNICAÇÃO (EX. REDES SOCIAIS, FERRAMENTAS DE BUSINESS INTELLIGENCE, ETC.)

1) Muito difícil

2) 2

3) 3

4) 4

5) 5

6) 6

7) 7

8) 8 
9) 9

10) Muito fácil

999 Sem resposta

QE6 - NOS ÚLTIMOS 12 MESES, VOCÊ REALIZOU TREINAMENTOS E CAPACITAÇÕES DE FORMAÇÃO CONTINUADA (CURSOS DE CURTA DURAÇÃO; APERFEIÇOAMENTO; ESPECIALIZAÇÃO; MESTRADO OU DOUTORADO)? CONSIDERE TREINAMENTOS E CAPACITAÇÕES INCENTIVADAS PELO SEU ÓRGÃO OU POR INICIATIVA PRÓPRIA.

0 Não

$1 \mathrm{Sim}$

999 Sem resposta

QE7 - COMO PARTE DA FORMAÇÃO, VOCÊ LEU UM OU MAIS ARTIGOS CIENTÍFICOS ESCRITOS POR ACADÊMICOS OU PESQUISADORES?

0 Não

1 Sim

999 Sem resposta

-888 Não se aplica

QEOB - NO QUE DIZ RESPEITO ÀS PRIORIDADES DO ESTADO BRASILEIRO, O QUANTO VOCÊ CONCORDA OU DISCORDA DAS AFIRMATIVAS ABAIXO? (RESPONDA EM UMA ESCALA DE 1 A 7, NA QUAL O PONTO 1 REPRESENTA "DISCORDO TOTALMENTE" E O PONTO 7 REPRESENTA "CONCORDO TOTALMENTE").

QE8 - O ESTADO BRASILEIRO, MAIS QUE OS INDIVÍDUOS, DEVE SER O RESPONSÁVEL PRINCIPAL PELA GARANTIA DO BEM-ESTAR DAS PESSOAS

1) Discordo totalmente

2) 2

3) 3

4) 4

5) 5

6) 6

7) Concordo totalmente 999 Sem resposta 
QE9 - O ESTADO BRASILEIRO, MAIS DO QUE O SETOR PRIVADO, DEVE SER O RESPONSÁVEL PRINCIPAL POR CRIAR EMPREGOS

1) Discordo totalmente

2) 2

3) 3

4) 4

5) 5

6) 6

7) Concordo totalmente 999 Sem resposta

QE10 - O ESTADO BRASILEIRO, NO LUGAR DO SETOR PRIVADO, DEVERIA SER DONO DAS EMPRESAS E INDÚSTRIAS MAIS IMPORTANTES DO PAÍS

1) Discordo totalmente

2) 2

3) 3

4) 4

5) 5

6) 6

7) Concordo totalmente 999 Sem resposta

QE11 - O ESTADO BRASILEIRO, MAIS DO QUE O SETOR PRIVADO, DEVE SER O RESPONSÁVEL PELO PROVIMENTO DE SERVIÇOS DE SAÚDE (HOSPITAIS)

1) Discordo totalmente

2) 2

3) 3

4) 4

5) 5

6) 6

7) Concordo totalmente

999 Sem resposta 
QE12 - O ESTADO BRASILEIRO DEVE IMPLEMENTAR POLÍTICAS FIRMES PARA REDUZIR A DESIGUALDADE DE RENDA ENTRE RICOS E POBRES

1) Discordo totalmente

2) 2

3) 3

4) 4

5) 5

6) 6

7) Concordo totalmente 999 Sem resposta

SEÇÃO F - PERFIL DEMOGRÁFICO E FUNCIONAL

QF1 - QUAL O SEU SEXO?

1) Masculino

2) Feminino

999 Sem resposta

QF2 - QUAL A SUA IDADE?

Entrada numérica: 0 a 99

999 Sem resposta

QF3 - QUAL A SUA RAÇA/COR/ETNIA?

1) Branca

2) Parda

3) Preta

4) Amarela

5) Indígena

999 Sem resposta

QF4 - QUAL FOI O CURSO DE NÍVEL MAIS ELEVADO QUE VOCÊ CONCLUIU?

1) Ensino fundamental

2) Ensino médio/técnico 
3) Graduação

4) Especialização (pós-graduação lato sensu, MBA, etc.)

5) Mestrado

6) Doutorado/pós-doutorado 999 Sem resposta

QF5 - QUAL A ÁREA DE FORMAÇÃO ACADÊMICA DA SUA MAIOR TITULAÇÃO?

1) Ciências agrárias (ex.: agronomia, veterinária, zootecnia, etc.)

2) Ciências biológicas (ex.: biologia, farmacologia, genética, etc.)

3) Ciências da saúde (ex.: medicina, farmácia, odontologia, nutrição, etc.)

4) Ciências exatas e da terra (ex.: física, matemática, química, etc.)

5) Ciências humanas (ex.: educaçáo, ciência política, história, antropologia, filosofia, sociologia, etc.)

6) Ciências sociais aplicadas (ex.: administração, economia, arquitetura, demografia, direito, comunicação, ciência da informação, etc.)

7) Engenharias (todas as engenharias, tais como civil, elétrica, mecatrônica, naval, etc.)

8) Linguística, artes e letras

9) Outros

999 Sem resposta

-888 Não se aplica

QF6 - VOCÊ POSSUI ALGUMA DEFICIÊNCIA (IMPEDIMENTO DE LONGO PRAZO DE NATUREZA FÍSICA, MENTAL, INTELECTUAL OU SENSORIAL)?

0 Não

1 Sim

999 Sem resposta

QF7 - QUAL?

1) Física/motora

2) Intelectual/mental

3) Visual 
4) Auditiva

999 Sem resposta

-888 Não se aplica

QF8 - VOCÊ ENCONTRA DIFICULDADES DE ACESSIBILIDADE EM CURSOS E EVENTOS DE CAPACITAÇÃO?

0 Não

1 Sim

999 Sem resposta

-888 Não se aplica 
Ipea - Instituto de Pesquisa Econômica Aplicada

Assessoria de Imprensa e Comunicação

EDITORIAL

\section{Coordenação}

Reginaldo da Silva Domingos

Assistente de Coordenação

Rafael Augusto Ferreira Cardoso

\section{Supervisão}

Camilla de Miranda Mariath Gomes

Everson da Silva Moura

\section{Editoração}

Aeromilson Trajano de Mesquita

Cristiano Ferreira de Araújo

Danilo Leite de Macedo Tavares

Herllyson da Silva Souza

Jeovah Herculano Szervinsk Junior

Leonardo Hideki Higa

\section{Capa}

Danielle de Oliveira Ayres

Flaviane Dias de Sant'ana

\section{Projeto Gráfico}

Renato Rodrigues Bueno

The manuscripts in languages other than Portuguese published herein have not been proofread.

\section{Livraria Ipea}

SBS - Quadra 1 - Bloco J - Ed. BNDES, Térreo

70076-900 - Brasília - DF

Tel.: (61) 2026-5336

Correio eletrônico: livraria@ipea.gov.br 

Composto em adobe garamond pro 12/16 (texto) Frutiger 67 bold condensed (títulos, gráficos e tabelas) Brasília-DF 



\section{Missão do Ipea}

Aprimorar as políticas públicas essenciais ao desenvolvimento brasileiro por meio da produção e disseminação de conhecimentos e da assessoria ao Estado nas suas decisões estratégicas.

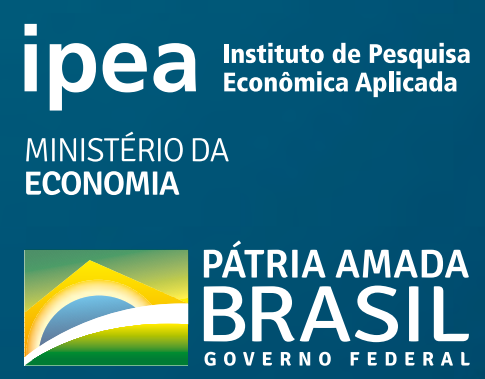

